\title{
Aptamer-Based Biosensors for Antibiotic Detection: A Review
}

\author{
Asol Mehlhorn, Parvaneh Rahimi * and Yvonne Joseph (iD \\ Institute of Electronic and Sensory Materials, Faculty of Materials Science and Materials Technology, \\ Technological University Freiberg, Akademie Str. 6, 09599 Freiberg, Germany; \\ Asol.Mehlhorn@esm.tu-freiberg.de (A.M.); yvonne.joseph@esm.tu-freiberg.de (Y.J.) \\ * Correspondence: Parvaneh.Rahimi@esm.tu-freiberg.de; Tel.: +49-3731-39-2644
}

Received: 26 April 2018; Accepted: 5 June 2018; Published: 11 June 2018

\begin{abstract}
Antibiotic resistance and, accordingly, their pollution because of uncontrolled usage has emerged as a serious problem in recent years. Hence, there is an increased demand to develop robust, easy, and sensitive methods for rapid evaluation of antibiotics and their residues. Among different analytical methods, the aptamer-based biosensors (aptasensors) have attracted considerable attention because of good selectivity, specificity, and sensitivity. This review gives an overview about recently-developed aptasensors for antibiotic detection. The use of various aptamer assays to determine different groups of antibiotics, like $\beta$-lactams, aminoglycosides, anthracyclines, chloramphenicol, (fluoro)quinolones, lincosamide, tetracyclines, and sulfonamides are presented in this paper.
\end{abstract}

Keywords: biosensor; aptasensor; aptamer; antibiotic; ampicillin; penicillin; gentamicin; kanamycin; neomycin; tobramycin; streptomycin; daunomycin; chloramphenicol; ciprofloxacin; danofloxacin; enrofloxacin; ofloxacin; lincomycin; oxytetracycline; tetracycline; sulfadimethoxine

\section{Introduction}

The increase of antibiotic-resistant germs is an acute challenge for consumer health protection and veterinary medicine. Inappropriate and prophylactic use of antibiotics (especially in the field of animal care) is common and associated with contamination of the environment with antibiotics and their metabolites. On one hand, this favors the development of antibiotic resistances of bacteria, while, on the other hand, this harms the environment, e.g., by uncontrolled disturbance of the ground flora [1-3]. To minimize the resistance towards antibiotics the use and the release of them into the environment must be first detected and, thereupon, can be limited [4].

In their original sense antibiotics are naturally-built low molecular weight metabolites of bacteria or fungi, which either kill or slow the growth of other microorganisms [5]. In the widest sense, partial synthetic derivates and chemically-synthesized compounds with antimicrobial effect belong to antibiotics. They are generally used for treating infections in modern healthcare [5]. According to their chemical structure and the resulting mode of action, antibiotics can be classified into different groups inter alia 8 -lactams, aminoglycosides, anthracyclines, (fluoro)quinolones, tetracyclines, lincosamide, and sulfonamides.

Currently, residue levels of antibiotics in aqueous samples are mainly detected by high-performance liquid chromatography (HPLC) [6-9], gas chromatography-mass spectrometry (GC-MS) [10], and liquid chromatography-tandem mass spectrometry (LC-MS/MS) [11-14]. Despite their wide range of applications, these methods are usually time-consuming, require laborious pretreatment of samples, sophisticated instrumentation, and trained technical personnel. The use of biosensors circumvent these problems and could ensure fast on-site analysis. Biosensors are analytical 
devices that contain two important functional components: a target recognition element (e.g., enzyme, protein, nucleic acid, or cell) and a signal transduction element [15]. According to their transducing element biosensors can be divided into mass-, optical-, and electrochemical-based biosensors $[15,16]$. Recently, several possible aptamer-based biosensors, known as aptasensors, have been developed for antibiotic detection. Aptamers are single-stranded DNA or RNA oligonucleotides, which can specifically bind to a wide range of target molecules, like nucleic acids, proteins, metal ions, and other small molecules with high affinity, selectivity, and sensitivity [17,18]. Due to such advantages in comparison to antibodies, aptamers are promising alternatives for most applications $[19,20]$. Suitable aptamers can be identified using a process called Systematic Evolution of Ligands by EXponential enrichment (SELEX) [17,18], first reported by Ellington et al. [17] and Tuerk and Gold [21]. In this approach, suitable binding sequences are first isolated from large oligonucleotide libraries and subsequently amplified. Aptamers can be produced at low cost and be easily modified with signal moieties [22]. Since the first publications of aptamer-based biosensors in 1996 by Drolet et al. [23] and Davis et al. [24] a variety of biosensors and assays have been successfully developed for aptamer-based analysis (recognition and detection) of different targets. Similar to the classical immunosorbent assays, aptamer assays can be designed as a single-site binding format, as a dual-site (sandwich) binding format, in which the analyte is sandwiched by a pair of aptamers, or a sandwich binding format with an aptamer and an antibody [25].

Aptasensors can be fabricated with various transducers that are mass-, optically-, or electrochemically sensitive. The corresponding transduction principles are given in Figure 1 . In quartz crystal microbalance (QCM, Figure 1a) and surface acoustic wave sensors (SAW, (Figure 1b) the change of the oscillation frequency of an acoustic wave due to a target binding is measured $[16,25]$. In QCM the acoustic wave is produced as a bulk acoustic wave, while in SAW sensors the wave travels along the surface of an elastic material with an amplitude that typically decreases exponentially with the substrate depth [26]). In micromechanical cantilever arrays (MCA, Figure 1c) aptamer-target binding leads to a change in the resonance frequency of the microcantilever (dynamic mode) or to a steric crowding that forces the cantilever to bend (static mode). The bending is detected optically or electronically $[16,25]$.

The most commonly used optical biosensors are based on colorimetric or fluorometric detection [27]. Colorimetry is the determination of the concentration of a substance in a (mostly) liquid phase by comparison with a color scale which, in turn, corresponds to a known concentration of the substance [28]. Colloid gold nanoparticles (AuNPs) have been broadly considered as a label for molecular sensing because of their diverse electronic and optical properties. They absorb and scatter light with high efficiency, are known as strong quenchers, and exhibit a wide range of colors [29]. Responsible for the colors is the phenomena of localized surface plasmon resonance (LSPR), in which the conducting electrons on the AuNPs surface collectively oscillate in resonance with incident light [30]. AuNPs possess a high surface free energy, good biocompatibility, and large surface area where molecules can be immobilized (e.g., aptamers), and are catalytically active [29,31]. In the gold nanoparticle-based colorimetric assay (CoA, Figure 1d) the aptamer is bound onto the surface of AuNPs and, thus, prevents their aggregation. Upon target binding the conformation of the aptamer changes from a random coil structure to a folded rigid structure; in consequence the adsorbed aptamers detach from the AuNPs and the AuNPs aggregate. This leads to a visible color change of the solution [27]. A limitation of AuNP-based colorimetric assays is the tendency of AuNPs to aggregate non-specifically in the presence of salt and other molecules present in the complex biological fluids [32]. In the fluorometric assay (FlA, Figure 1e) the aptamer is labelled with a fluorophore and an appropriate quencher. The binding of the target causes a conformational change of the aptamer and brings the fluorophore and quencher into close contact, whereupon the fluorescence is quenched [33]. This is known as "signal-off" mode. The reverse case, the "signal-on" mode, is possible too, whereby the conformational change upon target binding leads to a divergence of fluorophore and quencher, resulting in a fluorescence signal. Graphene oxide (GO) has been 
widely used as a fluorescence sensing platform because of its good biocompatibility, low cytotoxicity, and excellent capabilities for conjugation of target molecules [34]. GO and surface-modified graphene are highly efficient fluorescence quenchers based on either electron or energy transfer mechanisms [35,36]. Förster resonance energy transfer (FRET) is the mechanism of non-radiation (dipole-dipole) energy transfer from an excited chromophore (donor) to a second chromophore (acceptor) [37]. Upconversion nanoparticles (UCNPs) are nanoscale particles, exhibiting photon upconversion, which means that the sequential absorption of photons leads to the emission of light at shorter wavelengths than the excitation wavelength [38]. UCNPs possess a couple of advantages compared to other types of fluorescent materials, like organic dyes or fluorescent proteins, including higher photostability, low toxicity, large Stokes shifts, high quantum yields, and the lack of both auto-luminescence and a light-scattering background [39,40]. Quantum dots (QDs), semiconductor nanoparticles, belong to the UCNPs. Due to their influenceable optical and electronic properties, they are of interest for many applications and are applied as alternatives to molecular fluorophores in optical biosensors [41-43]. QDs are very small particles, with good conductivity, a high extinction coefficient, high chemical stability, broadband optical absorption, low toxicity and strong photoluminescence emission [44,45]. In contrast, the chemiluminescence resonance energy transfer (CRET) occurs by the oxidation of a chemiluminescent substrate without an excitation source [46]. The quantum mechanical phenomenon of the surface plasmon resonance (SPR, Figure 1f) is the fundamental principle behind many biosensor applications and different lab-on-a-chip systems utilized for detecting molecular interactions [25]. Polarized light, parallel to the incidence plane, strikes an electrically-conducting surface. Often thin metal films or semiconductor films, like gold, are used. At the interface between two media, a resonance interaction with oscillating electrons occurs, generating electron charge density waves, so-called surface plasmons which are totally reflected. When an analyte is bound, the refractive index of the film and, consequently, the resonance angle alters. Thus, the intensity of reflected light at a specific angle (known as the resonance angle) is changed, proportional to the mass on a sensor surface [28]. SPR is a versatile technique, in which no elaborate sample preparation and no radioactive or enzyme-labelled reagents are necessary [47]. The surface enhanced Raman scattering (SERS, Figure 1g) is a highly sensitive optical measurement method, that provides the signals based on the enhanced inelastic scattering of light on atoms or molecules (Raman scattering) immediate near a metal surface, often $\mathrm{Au}$ or $\mathrm{Ag}$, with nanoscale roughness [48].

The principle of an aptamer-based electrochemical biosensor is the following (Figure 1h): the aptamer is immobilized onto an electrode surface and labelled with a redox probe (often ferrocene), methylene blue (MB), or $\mathrm{Fe}_{3} \mathrm{O}_{4} \mathrm{NPs}$ ). Upon target-binding the conformational change of the aptamer brings the probe closer to the electrode surface. An electron transfer, and thereby an electrochemical readout, is possible [27], which is known as "signal on" mode. Alternatively the conformational change increases the distance between the redox probe and the surface electrode, resulting in an interruption of the previous electron transfer, designated as "signal off" mode [25]. A simultaneous detection of more than one target analyte is possible by using various metal ions, e.g., $\mathrm{Cd}^{2+}, \mathrm{Pb}^{2+}, \mathrm{Zn}^{2+}$, and $\mathrm{Cu}^{2+}$, with diverse redox potentials to produce distinguishable electrochemical signals [49]. These kinds of probes are designated as metal-labelled biocodes [49]. Usually electrochemical measurements are carried out in a conventional three-electrode system, containing a working electrode (e.g., Au or glassy carbon), a reference electrode (e.g., $\mathrm{Ag} / \mathrm{AgCl}$ or saturated calomel), an auxiliary electrode (e.g., platinum wire), and a redox probe in buffer solution (e.g., $\left.\left[\mathrm{Fe}(\mathrm{CN})_{6}\right]^{4-/ 3-}\right)$. Four types of electrochemical sensors are distinguished by their measuring principle: (a) conductometric-based, which sense the change of electrical charge in a solution under constant voltage; (b) potentiometric-based, which sense changes in the electrical potential difference upon binding; (c) amperometric-based, which sense the difference in current potentials during redox reactions when pairing occurs; and (d) impedimetric-based, which sense changes in impedance upon interaction [16]. 

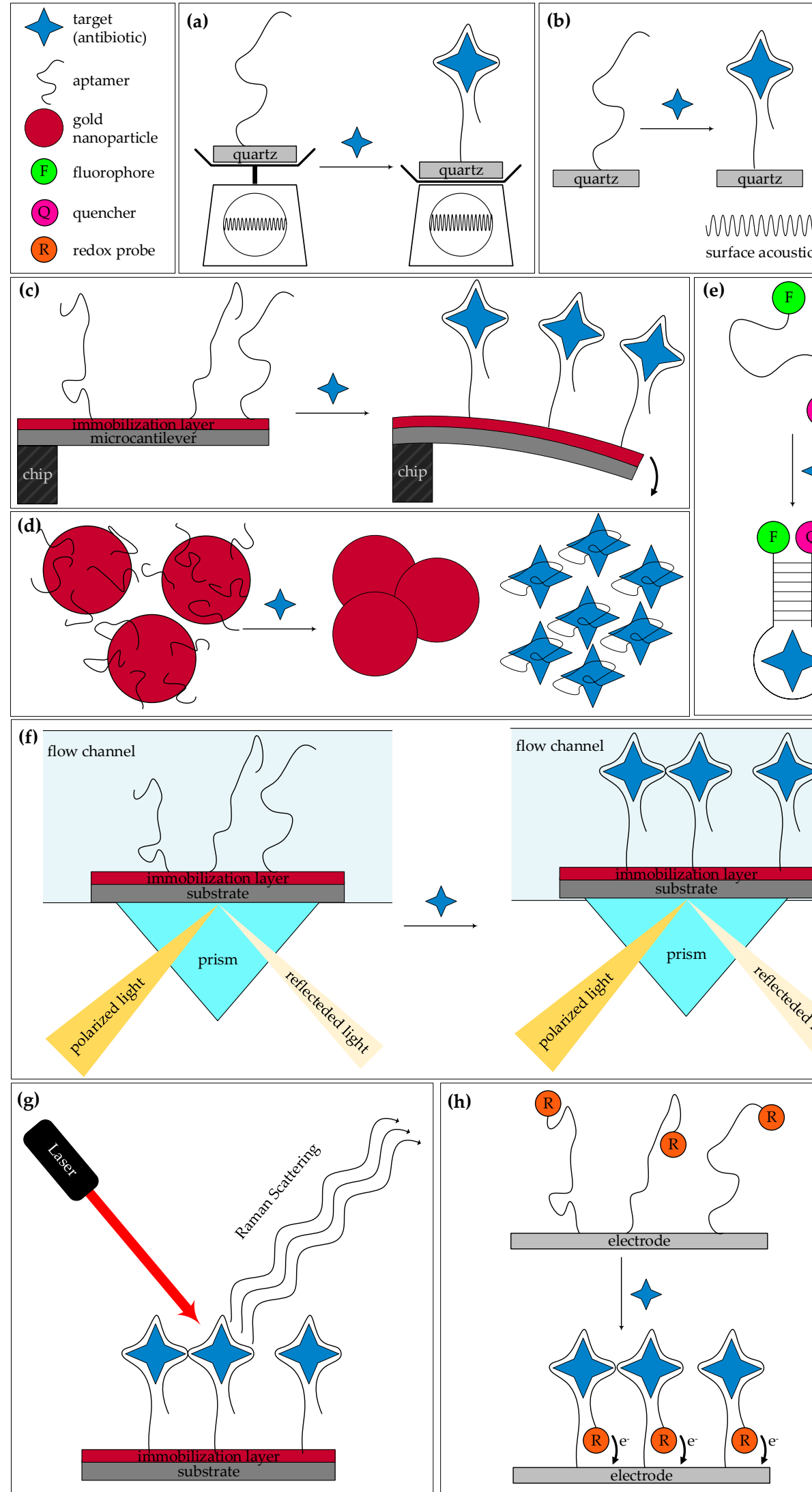

MOOWOWOWM surface acoustic wave
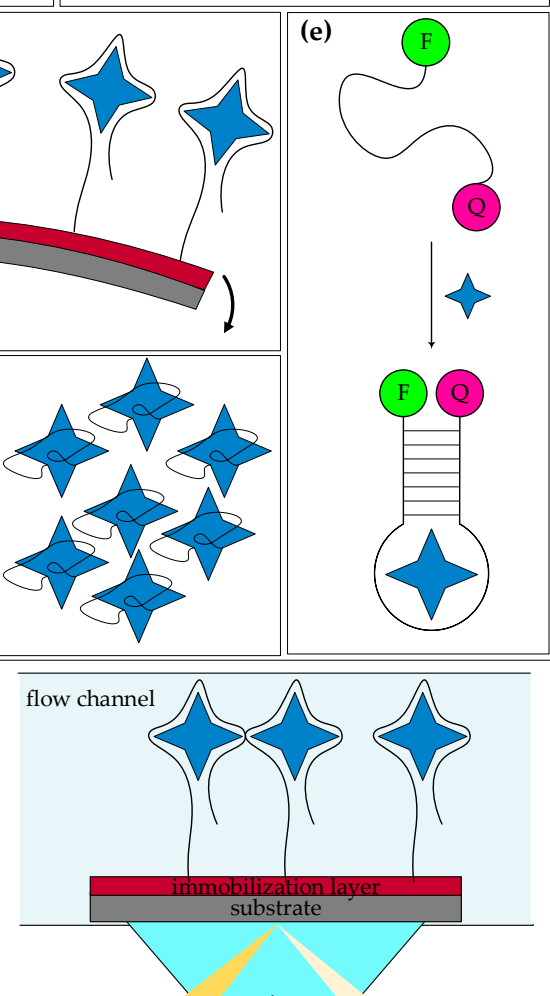

prism

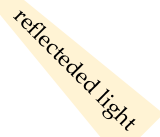

(h)

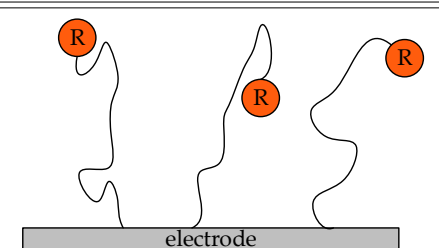

(R)

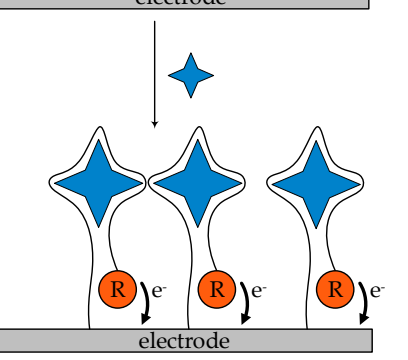

Figure 1. Working principles of the most widely used aptasensors. (a) Quartz crystal microbalance; (b) surface acoustic wave; (c) micromechanical cantilever array; (d) AuNPs based colorimetric aptasensor; (e) fluorometric aptasensor; (f) surface plasmon resonance; (g) surface enhanced Raman scattering; and (h) electrochemical aptasensor. 
More methods for antibiotic detection based on the mentioned basic principles are described in detail in the appropriate sections of the paper. Additionally, further detailed information about the operating modes for aptamer-based biosensors can be read inter alia in the reported review papers [50].

This systematic and comprehensive review discusses the application of aptamers in the detection of different antibiotic groups. In this section, eight different groups of antibiotics, and the designed aptasensors for their detection, are discussed.

\section{Aptasensors for Different Antibiotic Classes}

The various currently-developed aptamer-based biosensors for antibiotic detection mentioned in the literature are ordered by their antibiotic class and discussed below.

To compare the performance of aptasensors the following parameters or characteristics are important.

Affinity is a measure of the tendency of molecules to bind to other molecules [51]. The higher the affinity, the greater the association constant $\mathrm{K}_{\mathrm{A}}$. More common is the reciprocal value, the dissociation constant $\mathrm{K}_{\mathrm{D}}$. The higher the affinity of a target to its ligand, the lower the $\mathrm{K}_{\mathrm{D}}$ of the complex, thus, low $\mathrm{K}_{\mathrm{D}}$ values are preferred.

Selectivity is the property to select multiple objects from a set of objects, while specificity is the property to select one object from a set of objects [52]. Thus, an analytical method is selective when different components of a mixture can be determined side by side and without interference. The method is specific when only one component of the mixture can be determined. Specificity tests are usually carried out by target detection in the simultaneous presence of the target and structurally similar substances. High specificity and selectivity is preferred.

The limit of detection (LOD) is the lowest quantity of a substance that can be distinguished from the absence of that substance (a blank value) within a stated confidence limit [53]. The maximum residue levels (MRL) is the highest concentration of an undesirable substance (impurity or pollutant), that is legally permitted in a food or commodity [54], defined by the European Union, e.g., in Council Directive 96/23/EC [54] for antibiotic residues in live animals and animal products. The aim in the development of a biosensor is to achieve a low sensitivity, such that the LOD is smaller than the MRL.

The reproducibility is the repeatability of scientific research results [55].

The recovery is determined by a standard addition method. Defined target concentrations are added to real samples and the recovery is detected. Furthermore, the results are compared to results with an alternative method, the enzyme-linked immunosorbent assay (ELISA).

The applicability of the proposed aptasensor for real-sample analysis is verified by the detection of the target in real samples, such as milk, honey, serum, water, and others.

The stability is the ability of the sensor to maintain its performance under the prevailing conditions for a certain period of time. It is tested by storing the sensor at defined conditions up to several weeks, comparing the analytical performance before and after storage.

\section{1. $\beta$-Lactams}

Due to their high efficacy, low toxicity, and the possibility to derivatize them by means of chemical and enzymatic methods, $\beta$-lactam antibiotics are considered to be the most important antibiotics in terms of quantity and value [56]. Their mechanism of action is based on the prevention of the formation of peptide cross-linking in the bacterial cell wall (murein) [5]. Therefore, they act specifically on prokaryotes with a mureous cell wall. They are characterized by their representative $\beta$-lactam ring (marked in red in Figure 2). The most important data of the discussed aptasensors, for the $\beta$-lactams, include the aptamer sequence, dissociation constant $\left(\mathrm{K}_{\mathrm{D}}\right)$, limit of detection (LOD), real sample analysis (RSA), and applied sensor type, are summyarized in Tables 1 and 2. 
<smiles>CC1(C)SC2C(NC(=O)C(N)c3ccccc3)C(=O)N2C1C(=O)O</smiles>

(a)<smiles>CC1(C)SC2C(NC(=O)Cc3ccccc3)C(=O)N2C1C(=O)O</smiles>

(b)

Figure 2. Chemical structure of: (a) ampicillin and (b) penicillin G. The $\beta$-lactam ring is marked in red.

\subsubsection{Ampicillin}

The occurrence of penicillin-resistant strains has stimulated the search for new antibiotics, from which semi-synthetic penicillin, such as ampicillin, have been found [57]. Ampicillin (Figure 2a) is a widely used broad spectrum antibiotic in veterinary medicine for the treatment and prevention of primary respiratory, gastrointestinal, urogenital, and skin bacterial infections in food-producing animal and it has a low human toxicity [57].

Song et al. [58] reported the first aptasensor for ampicillin using AuNP-based dual fluorescence colorimetric methods. Ampicillin-specific aptamers were selected by magnetic bead-based SELEX, which was further used in other studies [59]. Another fluorescent aptasensor for ampicillin detection was reported by Luo et al. [60] using magnetic bead composites coated with AuNPs and a nicking enzyme, which showed more sensitive responses with the limit of detection of $0.07 \mathrm{ng} \mathrm{mL}{ }^{-1}$ compared to the first proposed aptasensor by Song et al.

Dapra et al. [59] designed an all-polymer impedimetric electrochemical microfluidic biosensor for the detection of ampicillin and kanamycin A. Cyclic olefin copolymer (Topas ${ }^{\circledR}$ ) was used as a substrate on the top and bottom of the constructed chip. Due to their biocompatibility a conductive polymer bilayer consisting of tosylate-doped poly(3,4-ethylenedioxythiophene) (PEDOT) and the hydroxymethyl derivate was used as the electrode material. In a similar system Rosati et al. [61] optimized the geometry of the electrodes and the microchannels (e.g., thickness, width) and, therefore, the performance of the designed impedimetric aptasensor. Additionally, the ampicillin-specific aptamer was equipped with an appended poly(T)-poly(C) sequence which allowed a direct immobilization on the electrodes when UV irradiation was applied [62].

In order to enhance the aptasensor response to ampicillin and signal amplification, two electrochemical aptasensors were developed with the help of polymerase and nicking endonuclease [63], which was used for the first time as the target-aptamer binding triggered quadratic recycling amplification for electrochemical detection of antibiotics, and target-initiated T7 exonuclease in a homogeneous electrochemical sensing system [64].

There are many reports on electrochemical-based aptamer sensing assays for the detection of ampicillin [63-68], which are summarized in Table 1. Among all existing electrochemical sensor assays, the proposed aptasensor based on DNA-functionalized AuNPs and ssDNA binding protein (SSB) as the electrochemical signal inhibition reagent showed higher sensitivity with a detection limit of $0.38 \mathrm{pM}[65]$. 
Table 1. Aptamer sequence, dissociation constant $\left(\mathrm{K}_{\mathrm{D}}\right)$, limit of detection (LOD), real sample analysis (RSA), and realized sensor type and measuring method for ampicillin, mentioned in the corresponding references (Ref). AC $=$ alternating current, $\mathrm{AEC}=$ amperometric electrochemical, apt $=$ aptamer, bsa $=$ bovine serum albumin, cDNA = complementary DNA, CO = colorimetric, CV = cyclic voltammetry, DPV = differential pulse voltammetry, EBFC = enzyme biofuel cell, $\mathrm{EIS}=$ electrochemical impedance spectrometry, FAM = fluorescein amidite, $\mathrm{FL}=$ fluorometric, hu = human urine, IEC = impedimetric electrochemical, $\mathrm{MB}=$ methylene blue, $\mathrm{m}=$ milk, $\mathrm{OCV}=$ open circuit voltage, $\mathrm{rw}=$ river water, sa = salvia, $\mathrm{SWV}=$ square wave voltammetry, and $\mathrm{w}=\mathrm{water}$.

\begin{tabular}{|c|c|c|c|c|c|c|c|}
\hline $\begin{array}{l}5^{\prime} \text { Linker } \\
\text { and Spacer }\end{array}$ & Aptamer Sequence $5^{\prime} \rightarrow 3^{\prime}$ & $\begin{array}{l}3^{\prime} \text { Linker } \\
\text { and Spacer }\end{array}$ & $\begin{array}{c}\mathrm{K}_{\mathrm{D}} \\
(\mathrm{nM})\end{array}$ & $\begin{array}{l}\text { LOD } \\
(\mathrm{nM})\end{array}$ & RSA & $\begin{array}{c}\text { Sensor } \\
\text { Type/Method }\end{array}$ & Ref. ${ }^{1}$ \\
\hline FAM & $\begin{array}{l}\text { I: GCG GGC GGT TGT ATA GCG G } \\
\text { II: TTA GTT GGG GTT CAG TTG G } \\
\text { III: CAC GGC ATG GTG GGC GTC GTG }\end{array}$ & - & $\begin{array}{l}\text { I: } 13.4 \\
\text { II: } 9.8 \\
\text { III: } 9: 4\end{array}$ & $\begin{array}{l}\text { I: } 1.4(\mathrm{dw}, \mathrm{FL}) \\
\text { I: } 5.7(\mathrm{~m}, \mathrm{FL}) \\
\text { I: } 14.3(\mathrm{dw}, \mathrm{CO}) \\
\text { I: } 28.6(\mathrm{~m}, \mathrm{CO})\end{array}$ & $\mathrm{m}$ & $\begin{array}{l}\text { FL, CO/ } \\
\text { UV-VIS }\end{array}$ & [58] \\
\hline- & $\begin{array}{l}\text { apt I: GCG GGC GGT TGT ATA GCG GTT TTT TT } \\
\text { apt II: GCG GGC GGT TGT ATA GCG GTT TTT TT } \\
\text { cDNA I: AAC CGC CCG CTT TC CTC AGC } \\
\text { cDNA II: AAC CGC CCG CTT TAC CTC AGC } \\
\text { cDNA III: AAC CGC CCG CTT TAC CTC AGC A } \\
\text { cDNA IV: AAC CGC CCG CTT TAC CTC AGC A } \\
\text { cDNA V: ACC GCC CGC TTT ACC TCA GCA } \\
\text { cDNA VI: CAA CCG CCC GCT TTA CCT CAG CA } \\
\text { cDNA VII: ACA ACC GCC CGC TTT ACC TCA GCA }\end{array}$ & $\begin{array}{l}\text { apt I: SH } \\
\text { apt II: }\end{array}$ & - & $\begin{array}{c}0.2(\mathrm{~b}) \\
\left(0.07 \times 10^{-6} \mathrm{~g} / \mathrm{L}\right)\end{array}$ & rw & FL & [60] \\
\hline $\mathrm{NH}_{2}-\mathrm{C}_{6}$ & GCG GGC GGT TGT ATA GCG G & - & 13.4 & $0.1(b)$ & $\mathrm{m}$ & IEC/EIS & {$[58,59]$} \\
\hline poly(T)-poly(C) & GCG GGC GGT TGT ATA GCG G & - & - & $0.1(b)$ & - & IEC/EIS & {$[61,62]$} \\
\hline- & - & - & - & $0.001(b)$ & $\mathrm{m}$ & $\mathrm{AEC} / \mathrm{DPV}$ & [63] \\
\hline MB & GCG GGC GGT TGT ATA GCG G & $\mathrm{A}_{10}$ & - & $0.004(b)$ & $\mathrm{m}$ & $\mathrm{AEC} / \mathrm{DPV}$ & [64] \\
\hline $\begin{array}{l}\text { apt: SH } \\
\text { cDNA: SH }\end{array}$ & $\begin{array}{l}\text { TGG GGG TTG AGG CTA AGC CGA C } \\
\text { cDNA: GTC TTA GCC TCA ACC CCC A }\end{array}$ & - & - & $0.00038(b)$ & $\mathrm{m}$ & $\mathrm{AEC} / \mathrm{DPV}$ & [65] \\
\hline $\mathrm{SH}-\left(\mathrm{CH}_{2}\right)_{6}$ & TTA GTT GGG GTT CAG TTG G & MB & & $\begin{array}{c}1000(\mathrm{AC}) \\
30,000(\mathrm{SWV})\end{array}$ & bsa, sa, m & $\mathrm{AEC} / \mathrm{AC}, \mathrm{SWV}$ & [66] \\
\hline
\end{tabular}


Table 1. Cont

\begin{tabular}{|c|c|c|c|c|c|c|c|}
\hline $\begin{array}{l}5^{\prime} \text { Linker } \\
\text { and Spacer }\end{array}$ & Aptamer Sequence $5^{\prime} \rightarrow 3^{\prime}$ & $\begin{array}{l}3^{\prime} \text { Linker } \\
\text { and Spacer }\end{array}$ & $\begin{array}{c}\mathrm{K}_{\mathrm{D}} \\
(\mathrm{nM})\end{array}$ & $\begin{array}{l}\text { LOD } \\
(\mathrm{nM})\end{array}$ & RSA & $\begin{array}{c}\text { Sensor } \\
\text { Type/Method }\end{array}$ & Ref. $^{1}$ \\
\hline $\mathrm{SH}-\left(\mathrm{CH}_{2}\right)_{6}$ & $\begin{array}{c}\text { apt: TTA GTT GGG GTT CAG TTG G } \\
\text { cDNA I: CCA ACT AA } \\
\text { cDNA II: CCC AAC TA } \\
\text { cDNA III: CCC AAC TAA } \\
\text { cDNA IV: CCC CAA CTA } \\
\text { CDNA V: CCC CAA CTA A } \\
\text { CDNA VI: ACC CCA ACT AA } \\
\text { CDNA VII:AAC CCC AAC TAA } \\
\text { cDNA VIII: GAA CCC CAA CTA A } \\
\text { cDNA IX: TGA ACC CCA ACT AA }\end{array}$ & $\mathrm{MB}$ & - & $30(b)$ & $\begin{array}{l}\mathrm{hu}, \mathrm{w}, \\
\mathrm{m}, \mathrm{sa}\end{array}$ & $\mathrm{AEC} / \mathrm{AC}$ & [67] \\
\hline $\begin{array}{l}\text { apt: } \mathrm{NH}_{2}-\left(\mathrm{CH}_{2}\right)_{6} \\
\text { cDNA: } \mathrm{SH}-\left(\mathrm{CH}_{2}\right)_{6}\end{array}$ & $\begin{array}{c}\text { TTT TGC GGG CGG TTG TAT AGC GG } \\
\text { cDNA: TTT TTT TTT CCG CTA TAC AAC CGC C }\end{array}$ & - & - & $0.003(b)$ & $\mathrm{m}$ & $\mathrm{EBFC} / \mathrm{CV}, \mathrm{OCV}$ & {$[68]$} \\
\hline
\end{tabular}




\subsubsection{Penicillin}

Penicillin G (Figure 2b) is used for the production of 6-aminopenicillanic acid (6-APA), the main intermediate product for the synthesis of semi-synthetic penicillins and cephalosporins [56]. It is the most frequently used $\beta$-lactam antibiotic for the prevention and treatment of bacterial infections, like scarlet fever, diphtheria, gonorrhoea, angina, and tetanus. Penicillin is produced by the fungi Penicillium notatum and is hardly humanly toxic [57].

The first aptasensor for detection of penicillin was reported by Zhao et al. [69]. They developed an electrochemical aptasensor using a composite film consisting of a magnetic graphene nanocomposite ( $\mathrm{GR}-\mathrm{Fe}_{3} \mathrm{O}_{4} \mathrm{NPs}$ ) and a poly(3,4-ethylenedioxythiophene)-gold nanoparticle composite (PEDOT-AuNPs) for the modification of the electrode to assemble the penicillin aptamer to it.

Paniel at al. [70] described the selection of aptamers selective to penicillin G using the capture-SELEX process. The process is based on the selection of DNA aptamers using the ssDNA fixed on a support, whereas the target is in solution. Selectivity tests showed that the aptamer was able to bind other $\beta$-lactam antibiotics, including amoxicillin and ampicillin, indeed with less affinity.

Lee et al. [71] identified ssDNA aptamers for the detection of penicillin $G$ by reduced graphene oxide-SELEX (rGO-SELEX). rGO-SELEX is a method which uses the $\pi$ - $\pi$ stacking interaction between rGO and nucleic acids for an immobilization-free selection of aptamers. Furthermore, rGO is an effective fluorescence quencher through the FRET effect. Thus, the fluorescence recovery signal from the quenched FAM-labelled aptamer on the rGO surface can give information about the binding of a target to the aptamer.

The comparison between the different aptasensors for penicillin G are shown in Table 2 . Although penicillin is an important and widely used antibiotic, only a few aptamer-based biosensors exist for its detection. Hence, there is still potential for research.

Table 2. Aptamer sequence, dissociation constant $\left(\mathrm{K}_{\mathrm{D}}\right)$, limit of detection (LOD), real sample analysis (RSA), and realized sensor type and measuring method for penicillin $\mathrm{G}$, mentioned in the corresponding references (Ref). $\mathrm{b}=$ buffer, EIS = electrochemical impedance spectrometry, FAM = fluorescein amidite, $\mathrm{FL}=$ fluorometric, and IEC = impedimetric electrochemical.

\begin{tabular}{|c|c|c|c|c|c|c|c|}
\hline $\begin{array}{l}5^{\prime} \text { Linker } \\
\text { and } \\
\text { Spacer }\end{array}$ & Aptamer Sequence $5^{\prime} \rightarrow 3^{\prime}$ & $\begin{array}{l}3^{\prime} \text { Linker } \\
\text { and } \\
\text { Spacer }\end{array}$ & $\begin{array}{c}\mathrm{K}_{\mathrm{D}} \\
(\mathrm{nM})\end{array}$ & $\begin{array}{l}\text { LOD } \\
(\mathrm{nM})\end{array}$ & RSA & $\begin{array}{l}\text { Sensor Type/ } \\
\text { Method }\end{array}$ & $\operatorname{Ref}^{1}$ \\
\hline- & $\begin{array}{l}\text { GGG AGG ACG AAG CGG AAC GAG ATG } \\
\text { TAG ATG AGG CTC GAT CCG AAT GCG TGA } \\
\text { CGT CTA TCG GAA TAC TCG TTT TTA CGC } \\
\text { CTC ATA AGA CAC GCC CGA CA }\end{array}$ & - & - & $\begin{array}{c}0.49(\mathrm{~b}) \\
\left(0.17 \times 10^{-6} \mathrm{~g} / \mathrm{L}\right)\end{array}$ & $\mathrm{m}$ & IEC/EIS & [70] \\
\hline FAM & $\begin{array}{l}\text { GGG TCT GAG GAG TGC GCG GTG CCA } \\
\text { GTG AGT }\end{array}$ & - & 383.4 & $9.2(b)$ & $\mathrm{m}$ & FL & [71] \\
\hline $\mathrm{NH}_{2}$ & $\begin{array}{c}\text { CTG AAT TGG ATC TCT CTT CTT GAG CGA } \\
\text { TCT CCA CA }\end{array}$ & - & - & $0.057(b)$ & $\mathrm{m}$ & IEC/EIS & {$[69]^{2}$} \\
\hline
\end{tabular}

${ }^{1}$ When naming several references, the first always describes the realized sensor with associated LOD; aptamer sequence(s) and/or associated $\mathrm{K}_{\mathrm{D}}$ values are derived from the additional reference(s). ${ }^{2}$ The exact subcategory of the substance is not mentioned. 


\subsection{Aminoglycosides}

Aminoglycoside antibiotics are the most commonly used antibiotics worldwide, with a broad spectrum of activity-also against Gram-negative bacteria [56]. Despite their relatively high toxicity (especially on the ears and kidneys), they are the antibiotics of severe infections which, in turn, leads to an increase in resistance [56]. They exert their effect by binding to the $30 \mathrm{~S}$ subunit of ribosomes, which leads to reading errors during translation and, ultimately, inhibition of protein biosynthesis [56]. The basic structure of most aminoglycoside antibiotics consists of an aminocyclitol ring which is linked glycosidically to other amino sugars (Figure 3) [57]. The most important data of the discussed aptasensors, for the aminoglycosides including aptamer sequence, $\mathrm{K}_{\mathrm{D}}$, LOD, RSA, and applied sensor type, are summarized in Tables 3-7.
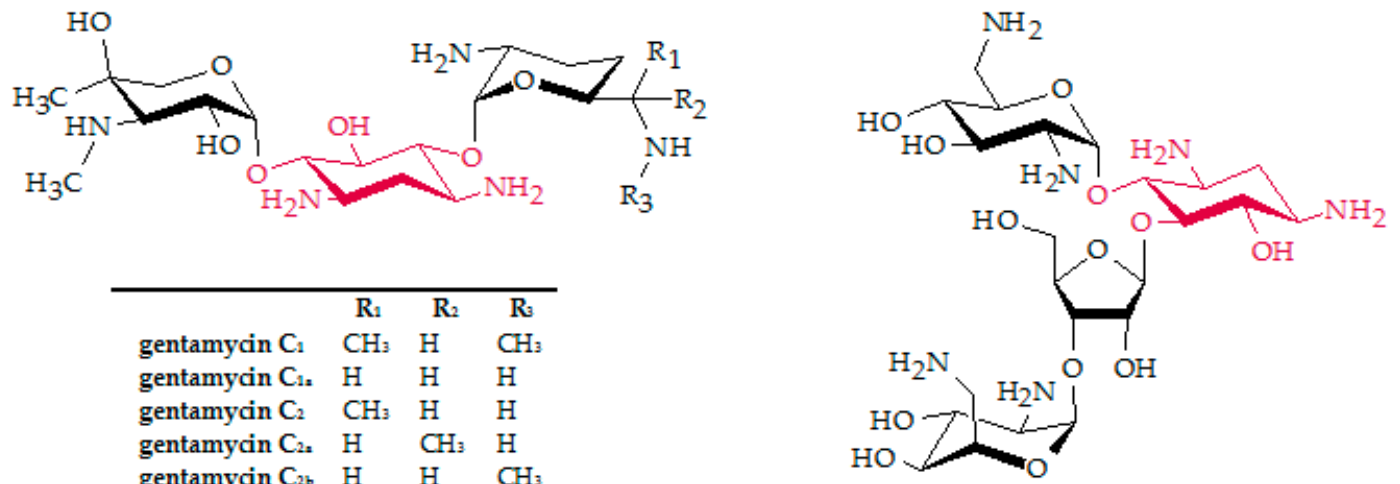

(a)

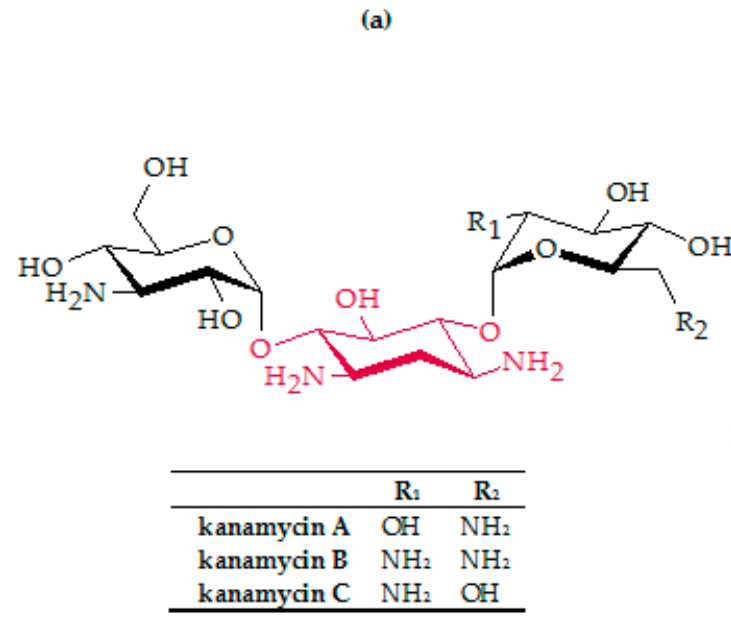

(b) (c)

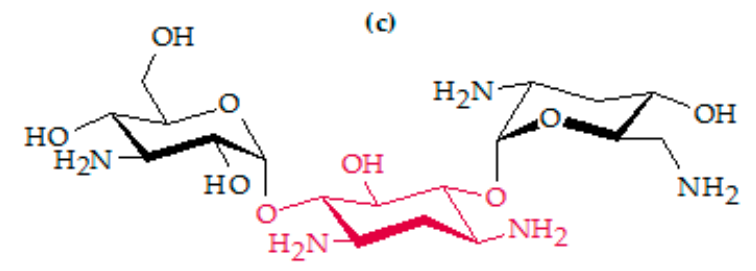

(d)

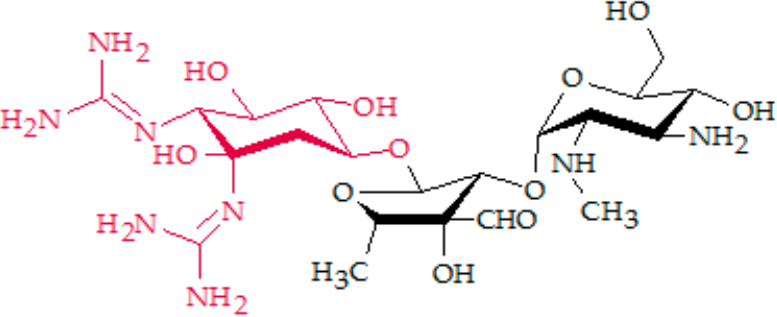

(e)

Figure 3. Chemical structure of: (a) gentamicin; (b) kanamycin; (c) neomycin B; (d) tobramycin; and (e) streptomycin. The basic structure of aminoglycoside antibiotics consists of an aminocyclitol ring (marked in red) which is linked glycosidically to other amino sugars. 


\subsubsection{Gentamicin}

The alkaline aminoglycoside antibiotic gentamicin (Figure 3a), isolated in 1963, is a broad-spectrum antibiotic and acts as a bactericide against a large number of Gram-positive and Gram-negative pathogens, such as E. coli and Pseudomonas [56]. It is used especially for severe wound infections and accidental injuries, as well as secondary infections after burns [56]. Therapeutically-used gentamicin usually contains $70 \%$ of the $\mathrm{C}_{1}$ and $30 \%$ of the $\mathrm{C}_{2}$ component (Figure 3a) [56]. Gentamicin is less toxic than kanamycin, neomycin, and streptomycin. However, ototoxic and nephrotoxic damage have been observed [56].

Rowe et al. [72] designed an electrochemical aptasensor based on RNA-aptamers and DNA-aptamers for the detection of the aminoglycoside antibiotics gentamicin, tobramycin, and kanamycin in blood samples in order to prevent overdosage and side effects. DNA aptamers were more stable, but the SWV experiments showed a lower sensitivity of the DNA-aptamer-based sensor to detect aminoglycosides in blood samples compared to the RNA-based sensor. The most important data of the developed sensor given in Table 3.

This work is the only aptasensor for gentamicin detection studied up to now in the literature, therefore, great potential exists for further research.

Table 3. Aptamer sequence, dissociation constant $\left(K_{D}\right)$, limit of detection (LOD), real sample analysis (RSA), and realized sensor type and measuring method for gentamicin, mentioned in the corresponding references (Ref). AEC = amperometric electrochemical, hs = human serum, $\mathrm{MB}=$ methylene blue, and $\mathrm{SWV}=$ square wave voltammetry.

\begin{tabular}{|c|c|c|c|c|c|c|c|}
\hline $\begin{array}{l}5^{\prime} \text { Linker } \\
\text { and Spacer }\end{array}$ & Aptamer Sequence $5^{\prime} \rightarrow 3^{\prime}$ & $\begin{array}{l}3^{\prime} \text { Linker } \\
\text { and Spacer }\end{array}$ & $\begin{array}{c}\mathrm{K}_{\mathrm{D}} \\
(\mathrm{nM})\end{array}$ & $\begin{array}{l}\text { LOD } \\
\text { (nM) }\end{array}$ & RSA & $\begin{array}{l}\text { Sensor Type/ } \\
\text { Method }\end{array}$ & $\operatorname{Ref}^{1}$ \\
\hline $\begin{array}{l}\text { I: SH } \\
\text { II: SH } \\
\text { III: SH }\end{array}$ & $\begin{array}{l}\text { I: GGG ACU UGG UUU } \\
\text { AGG UAA UGA GUC CC } \\
\text { II: (fully O-methylated) } \\
\text { GGG ACU UGG UUU } \\
\text { AGG UAA UGA GUC CC } \\
\text { III: GGG ACT TGG TTT } \\
\text { AGG TAA TGA GTC CC }\end{array}$ & $\begin{array}{l}\text { I: NH-MB } \\
\text { II: NH-MB } \\
\text { III: NH-MB }\end{array}$ & $\begin{array}{c}\text { I: } 72,000 \\
\text { II: } \approx 80,000 \\
\text { III: } \approx 200,000\end{array}$ & - & hs & AEC/SWV & {$[72,73]$} \\
\hline
\end{tabular}

\footnotetext{
1 When naming several references, the first always describes the realized sensor with associated LOD;
} aptamer sequence(s) and/or associated $\mathrm{K}_{\mathrm{D}}$ values are derived from the additional reference(s).

\subsubsection{Kanamycin}

Kanamycin (Figure 3b) is a bactericidal antibiotic isolated from Streptomyces kanamyceticus, whose spectrum of activity comprises Gram-positive and Gram-negative bacteria [56]. It is widely used as a veterinary drug and as a second-line antibiotic to treat serious infections, such as pneumonia, septicemia, urinary tract infections, and intestinal infections [72]. If not explained in more detail, kanamycin stands for a mixture of kanamycin A, B, and C, in which kanamycin A has the largest share [57]. Since sensitive and selective methods to detect kanamycin residues for food safety and clinical diagnosis are of great interest, there are more reports in kanamycin aptamer-based sensors in comparison to other antibiotics.

Song et al. [74] discovered the kanamycin-specific aptamer, which was later used in a variety of other studies [75] (Table 4). They selected the aptamer in vitro by SELEX using affinity chromatography with kanamycin-immobilized sepharose beads. The specific aptamers were immobilized onto the AuNPs to fabricate a colorimetric-based aptasensor. In the presence of kanamycin, the addition of salt leads to an aggregation of the modified AuNPs, which results in a color change from red to purple.

There are several reports for kanamycin detection using different colorimetric-based biosensing assays, due to its low cost, simplicity, and observation of the color change by the naked eye [32,74-79]. However, among them, silver nanoparticles (AgNPs) and AuNP-based colorimetric aptasensors have attracted more and more attention due to size/distance-dependent optical properties [76,77]. 
Thus, different research groups have tried to design a sensitive and specific kanamycin aptasensor based on AgNPs and AuNPs for the possible application in food or clinical samples [76-79].

Wang et al. [80] designed a colorimetric aptasensor for the detection of kanamycin based on liquid crystal film. Amino-functionalized kanamycin-specific aptamers and $\mathrm{N}, \mathrm{N}$-dimethyl- $\mathrm{N}-(3-$ (trimethoxysilyl)propyl)-1-octadecanaminiuchloride (DMOAP) were co-immobilized onto the surface of a glass slide, resulting in a homeotropic orientation of the liquid crystal film. The addition of kanamycin resulted in the formation of G-quadruplex structures, which destroyed the oriented arrangement of the liquid crystals on the surface and caused a visible color change from pink to green.

Fluorescence, as one of the most common optical techniques, has been used in the fabrication of aptasensors for kanamycin detection [81-90]. Generally, the binding affinity of an aptamer towards its target decreases by tagging the aptamer with a fluorescent dye [83]. Therefore, it is needed to improve the sensitivity of the designed aptasensors. Regarding this fact, different strategies have been employed for amplification of fluorometric signals. Nanoparticles (NPs), due to their advantages, can be used as the modifier films and improve the sensitivity of fluorometric aptasensors. Different NPs have been employed in the construction of highly sensitive fluorometric aptasensors, like silica NP (SNPs) [81], amino- $\mathrm{Fe}_{3} \mathrm{O}_{4}$ magnetic NPs [82], AuNPs [84], and UCNPs [86]. Immobilization of aptamers on the surface of reduced graphene oxide (rGO) [88] and carbon nanotubes (CNTs) [89] have showed great promise in the amplification of fluorometric signals in the detection of kanamycin. Moreover, Wang et al. [87] developed a fluorometric aptasensor, based on $\mathrm{MoS}_{2}$ nanosheets and carbon dots. The quenching ability of layered $\mathrm{MoS}_{2}$ was tested and compared to that of GO and AuNPs and showed comparable, or even better, values.

Chemiluminescence-based aptasensor in comparison with other optical aptasensors, like fluorometric and colorimetric aptasensors, has the lowest LOD [88]. However, there are a few reports in aptamer-based luminescence methods for the detection of kanamycin [91-93], which are summarized in Table 4. 
Table 4. Aptamer sequence, dissociation constant $\left(\mathrm{K}_{\mathrm{D}}\right)$, limit of detection (LOD), real sample analysis (RSA), and realized sensor type and measuring method for kanamycin, mentioned in the corresponding references (Ref). apt $=$ aptamer, $\mathrm{AEC}=$ amperometric electrochemical, $\mathrm{b}=\mathrm{buffer}, \mathrm{bs}=\mathrm{blood}$ serum, $\mathrm{c}=\mathrm{chicken}$, $\mathrm{CA}=$ chronoamperometry, $\mathrm{CAN}=$ cantilever, cap $=$ capture probe, $\mathrm{cDNA}=$ complementary DNA, $\mathrm{CO}=$ colorimetric, $\mathrm{cy}=\mathrm{cyanine}$ dye, $\mathrm{DPV}=$ differential pulse voltammetry, $\mathrm{ECL}=$ electrochemiluminescent, $\mathrm{EIS}=$ electrochemical impedance spectrometry, $\mathrm{f}=$ fish, $\mathrm{FAM}=$ fluorescein amidite, $\mathrm{FL}=\mathrm{fluorometric}$, hs $=$ human serum, IEC = impedimetric electrochemical, $\mathrm{LCA}=$ liquid crystal assay, lw = lake water, $\mathrm{m}=$ milk, $\mathrm{MB}=$ methylene blue, $\mathrm{p}=$ pork, $\mathrm{PEC}=$ photoelectrochemical, $\mathrm{rs}=$ rat serum, $\mathrm{ROX}=6$-carboxyl-x-rhodamine, $\mathrm{SWV}=$ square wave voltammetry, and $\mathrm{ww}=$ waste water.

\begin{tabular}{|c|c|c|c|c|c|c|c|}
\hline $\begin{array}{l}5^{\prime} \text { Linker } \\
\text { and Spacer }\end{array}$ & Aptamer Sequence $5^{\prime} \rightarrow 3^{\prime}$ & $\begin{array}{l}3^{\prime} \text { Linker and } \\
\text { Spacer }\end{array}$ & $\begin{array}{c}\mathrm{K}_{\mathrm{D}} \\
(\mathrm{nM})\end{array}$ & $\begin{array}{l}\text { LOD } \\
(\mathrm{nM})\end{array}$ & RSA & $\begin{array}{l}\text { Sensor Type/ } \\
\text { Method }\end{array}$ & $\operatorname{Ref}^{1}$ \\
\hline $\mathrm{SH}-\left(\mathrm{CH}_{2}\right)_{6}$ & TGG GGG TTG AGG CTA AGC CGA C & - & - & $50000(\mathrm{~b})$ & - & CAN & [94] \\
\hline- & TGG GGG TTG AGG CTA AGC CGA & - & 78.8 & 25 (b) & - & $\begin{array}{l}\mathrm{CO} / \\
\mathrm{UV}-\mathrm{VIS}\end{array}$ & {$[74]$} \\
\hline- & TGG GGG TTG AGG CTA AGC CGA & - & 78.8 & - & - & $\begin{array}{c}\mathrm{CO} / \\
\mathrm{UV}-\mathrm{VIS} \\
\end{array}$ & {$[74,75]$} \\
\hline- & TGG GGG TTG AGG CTA AGC CGA & - & 8.38 & $1.49(\mathrm{~b})$ & - & $\mathrm{CO}$ & {$[32,74]$} \\
\hline $\mathrm{SH}-\left(\mathrm{CH}_{2}\right)_{6}$ & TGG GGG TTG AGG CTA AGC CGA & - & - & $0.014(b)$ & $\mathrm{m}$ & $\begin{array}{c}\mathrm{CO} / \\
\mathrm{UV}-\mathrm{VIS}\end{array}$ & {$[74,95]$} \\
\hline- & TGG GGG TTG AGG CTA AGC CGA & - & - & $\begin{array}{c}4.5(\mathrm{~b}) \\
\left(2.6 \times 10^{-6} \mathrm{~g} / \mathrm{L}\right)\end{array}$ & $\mathrm{m}$ & $\mathrm{CO}$ & [77] \\
\hline- & CGG AAG CGC GCC ACC CCA TCG GCG GGG GCG AAG CTT GCG & - & - & $3.35(\mathrm{~b})$ & $\mathrm{m}$ & $\mathrm{CO}$ & {$[78,85]$} \\
\hline $\begin{array}{c}\text { apt: } \mathrm{SH}-\left(\mathrm{CH}_{2}\right)_{6} \\
\text { cDNA I: } \\
\text { SH- }\left(\mathrm{CH}_{2}\right)_{6} \\
\text { cap: } \\
\text { biotin }\end{array}$ & $\begin{array}{l}\text { apt: TGG GGG TTG AGG CTA AGC CGA } \\
\text { cDNA I: TCA GTC GGC TTA GCC GTC CAA CGT CAG ATC C } \\
\text { cap: CCG ATG GAT CTG ACG T }\end{array}$ & apt: biotin & & $0.0778(b)$ & $\mathrm{m}, \mathrm{h}$ & $\mathrm{CO}$ & [79] \\
\hline- & TGG GGG TTG AGG CTA AGC CGA & $\mathrm{NH}_{2}-\left(\mathrm{CH}_{2}\right)_{6}$ & - & $<1(b)$ & - & LCA & {$[74,80]$} \\
\hline $\begin{array}{l}\text { apt: biotin } \\
\text { cDNA: FAM }\end{array}$ & $\begin{array}{l}\text { apt: AGA TGG GGG TTG AGG CTA AGC CGA } \\
\text { cDNA: CTT AGC CTC AAC CCC CAT CT }\end{array}$ & - & - & $\begin{array}{l}0.612(\mathrm{~b}) \\
0.453(\mathrm{rs}) \\
\end{array}$ & rs & FL & [81] \\
\hline $\begin{array}{l}\text { apt: biotin } \\
\text { cDNA: ROX }\end{array}$ & $\begin{array}{l}\text { apt: TGG GGG TTG AGG CTA AGC CGA } \\
\text { cDNA: TCG GCT TAG CCT CAA CCC CCA }\end{array}$ & - & - & $\begin{array}{c}1.58(\mathrm{~b}) \\
\left(0.92 \times 10^{-6} \mathrm{~g} / \mathrm{L}\right)\end{array}$ & $\mathrm{m}, \mathrm{h}, \mathrm{p}$ & FL & {$[74,82]$} \\
\hline- & AGA TGG GGG TTG AGG CTA AGC CGA & - & - & $\begin{array}{l}0.321(\mathrm{~b}) \\
0.476(\mathrm{~m}) \\
0.568(\mathrm{rs})\end{array}$ & $\mathrm{m}, \mathrm{rs}$ & FL & {$[58,83,90]$} \\
\hline- & apt: TGG GGG TTG AGG CTA AGC CGA & - & - & $59(\mathrm{~b})$ & $\mathrm{m}$ & FL & {$[74,89]$} \\
\hline $\mathrm{NH}_{2}$ & AGA TGG GGG TTG AGG CTA AGC CGA & - & - & $\begin{array}{c}0.009(\mathrm{~b}) \\
0.018(\mathrm{bs})\end{array}$ & bs & FL & [84] \\
\hline
\end{tabular}


Table 4. Cont.

\begin{tabular}{|c|c|c|c|c|c|c|c|}
\hline $\begin{array}{l}5^{\prime} \text { Linker } \\
\text { and Spacer }\end{array}$ & Aptamer Sequence $5^{\prime} \rightarrow 3^{\prime}$ & $\begin{array}{l}3^{\prime} \text { Linker and } \\
\text { Spacer }\end{array}$ & $\begin{array}{c}\mathrm{K}_{\mathrm{D}} \\
(\mathrm{nM})\end{array}$ & $\begin{array}{l}\text { LOD } \\
(\mathrm{nM})\end{array}$ & RSA & $\begin{array}{l}\text { Sensor Type/ } \\
\text { Method }\end{array}$ & $\operatorname{Ref}^{1}$ \\
\hline II: FAM & $\begin{array}{l}\text { I: ATG CGG ATC CCG CGC GAC CAA CGG AAG CGC GCC ACC CCA } \\
\text { TCG GCG GGC GCG AAG CTT GCG C } \\
\text { II: CGG AAG CGC GCC ACC CCA TCG GCG GGC GCG AAG CTT GCG }\end{array}$ & - & II: 92.3 & $\begin{array}{l}\text { I: } 6.25 \text { (b) } \\
\text { II: } 6.25 \text { (b) } \\
\text { II: } 0.001 \text { (st) } \\
\text { II: } 0.1 \text { (bs) } \\
\text { II: } 0.02 \text { (m) }\end{array}$ & $\mathrm{m}, \mathrm{bs}$ & FL & [85] \\
\hline apt I: FAM & $\begin{array}{c}\text { apt I: TGG GGG TTG AGG CTA AGC CGA } \\
\text { apt II: TGG GGG TT FAM GAG GCT AAG CCG A } \\
\text { apt III: TGG GGG TTG AGG CTA AGC CGA } \\
\text { cDNA I: AAC CCC } \\
\text { cDNA II: AAC CCC A } \\
\text { cDNA III: AAC CCC CAA CT }\end{array}$ & $\begin{array}{l}\text { cDNA I: FAM } \\
\text { cDNA II: FAM } \\
\text { cDNA III: FAM }\end{array}$ & - & $0.4(b)$ & $\mathrm{m}$ & FL & [86] \\
\hline $\mathrm{NH}_{2}-\mathrm{C}_{6}$ & TGG GGG TTG AGG CTA AGC CGA C & - & - & $1100(\mathrm{~b})$ & $\mathrm{m}$ & FL & [87] \\
\hline $\begin{array}{c}\text { apt II: Cy3 } \\
\text { apt III: Cy5 } \\
\text { anchor apt: } \mathrm{NH}_{2} \\
\text { cDNA II: } \mathrm{Cy3}\end{array}$ & $\begin{array}{c}\text { apt I: TGG GGG TTG AGG CTA AGC CGA } \\
\text { apt II: TGG GGG TTG AGG CTA AGC CGA } \\
\text { apt III: TGG GGG TTG AGG CTA AGC CGA } \\
\text { apt IV: TGG GGG TTG AGG CTA AGC CGA } \\
\text { anchor apt: TTT TTT TGG GGG TTG AGG CTA AGC CGA } \\
\text { cDNA I: TAG CCT CAA } \\
\text { cDNA II: TCG GCT TAG CCT }\end{array}$ & $\begin{array}{l}\text { apt IV: Cy3 } \\
\text { cDNA I: Cy3 }\end{array}$ & & $26(b)$ & $\mathrm{m}$ & FL & {$[74,90]$} \\
\hline- & TGG GGG TTG AGG CTA AGC CGA & - & 78.8 & $143(b)$ & $\mathrm{f}$ & ECL & {$[74,91]$} \\
\hline $\mathrm{SH}-\left(\mathrm{CH}_{2}\right)_{6}-\mathrm{T}_{5}$ & $\begin{array}{c}\text { TGG GGG TTG AGG CTA AGC CGA } \\
\text { G-quadruplex: GGT TGG TGT GGT TGG TAG CCT CAA GGT TGG TGT } \\
\text { GGT TGG }\end{array}$ & - & - & $0.045(b)$ & $\mathrm{m}$ & ECL & [92] \\
\hline $\begin{array}{c}\text { apt: } \\
\text { biotin } \\
\text { cDNA: } \\
\text { SH- }\left(\mathrm{CH}_{2}\right)_{6}\end{array}$ & $\begin{array}{l}\text { apt: TGG GGG TTG AGG CTA AGC CGA } \\
\text { cDNA: TTA GCC TCA A }\end{array}$ & - & - & $\begin{array}{c}0.034(\mathrm{~b}) \\
\left(0.002 \times 10^{-6} \mathrm{~g} / \mathrm{L}\right)\end{array}$ & $\mathrm{m}$ & ECL & [93] \\
\hline- & TGG GGG TTG AGG CTA AGC CGA & - & - & $0.2(b)$ & - & PEC & [96] \\
\hline $\mathrm{SH}-\left(\mathrm{CH}_{2}\right)_{6}$ & TGG GGG TTG AGG CTA AGC CGA & - & - & $0.1(b)$ & - & PEC/EIS, CA & [97] \\
\hline $\mathrm{SH}-\left(\mathrm{CH}_{2}\right)_{6}$ & TGG GGG TTG AGG CTA AGC CGA & - & - & $\begin{array}{c}7.2(\mathrm{~b}) \\
\left(3.5 \times 10^{-6} \mathrm{~g} / \mathrm{L}\right)\end{array}$ & $\mathrm{m}$ & PEC/EIS & {$[97,98]$} \\
\hline- & TGG GGG TTG AGG CTA AGC CGA & - & - & $1.0(b)$ & $\mathrm{m}$ & IEC/EIS & [76] \\
\hline- & TGG GGG TTG AGG CTA AGC CGA & - & - & $\begin{array}{c}0.23 \\
\left(0.11 \times 10^{-6} \mathrm{~g} / \mathrm{L}\right)\end{array}$ & $\mathrm{m}$ & IEC/EIS & {$[74,99]$} \\
\hline
\end{tabular}


Table 4. Cont.

\begin{tabular}{|c|c|c|c|c|c|c|c|}
\hline $\begin{array}{l}5^{\prime} \text { Linker } \\
\text { and Spacer }\end{array}$ & Aptamer Sequence $5^{\prime} \rightarrow 3^{\prime}$ & $\begin{array}{l}3^{\prime} \text { Linker and } \\
\text { Spacer }\end{array}$ & $\begin{array}{c}\mathrm{K}_{\mathrm{D}} \\
(\mathrm{nM})\end{array}$ & $\begin{array}{l}\text { LOD } \\
(\mathrm{nM})\end{array}$ & RSA & $\begin{array}{l}\text { Sensor Type/ } \\
\text { Method }\end{array}$ & $\operatorname{Ref}^{1}$ \\
\hline $\begin{array}{l}\text { I: SH } \\
\text { II: SH } \\
\text { III: SH }\end{array}$ & $\begin{array}{l}\text { I: GGG ACU UGG UUU AGG UAA UGA GUC CC } \\
\text { II: (fully O-methylated) } \\
\text { GGG ACU UGG UUU AGG UAA UGA GUC CC } \\
\text { III: GGG ACT TGG TTT AGG TAA TGA GTC CC }\end{array}$ & $\begin{array}{l}\text { I: NH-MB } \\
\text { II: NH-MB } \\
\text { III: NH-MB }\end{array}$ & $\begin{array}{l}\text { I: } 281,000 \\
\text { II: } \approx 450,000 \\
\text { III: } \approx 600,000\end{array}$ & - & hs & $\mathrm{AEC} / \mathrm{SWV}$ & {$[72,73]$} \\
\hline $\mathrm{NH}_{2}$ & TGG GGG TTG AGG CTA AGC CGA C & - & 78.8 & $\begin{aligned} 9.4 & \pm 0.4(\mathrm{~b}) \\
10.8 & \pm 0.6(\mathrm{~m})\end{aligned}$ & $\mathrm{m}$ & $\mathrm{AEC} / \mathrm{SWV}$ & [100] \\
\hline $\begin{array}{l}\text { I: } \mathrm{NH}_{2} \\
\text { II: biotin }\end{array}$ & $\begin{array}{l}\text { I: TGG GGG TTG AGG CTA AGC CGA C } \\
\text { II: TGG GGG TTG AGG CTA AGC CGA C }\end{array}$ & - & - & $5.8(b)$ & $\mathrm{m}$ & $\mathrm{AEC} / \mathrm{DPV}$ & [101] \\
\hline $\begin{array}{l}\mathrm{I} \mathrm{NH}_{2} \\
\text { II biotin }\end{array}$ & $\begin{array}{l}\text { I: TGG GGG TTG AGG CTA AGC CGA C } \\
\text { II: TGG GGG TTG AGG CTA AGC CGA C }\end{array}$ & - & - & $8.6(b)$ & $\mathrm{m}$ & $\mathrm{AEC} / \mathrm{DPV}$ & [102] \\
\hline biotin & TGG GGG TTG AGG CTA AGC CG & - & - & $\begin{array}{c}7.9(\mathrm{~b}) \\
\left(4,6 \times 10^{-6} \mathrm{~g} / \mathrm{L}\right)\end{array}$ & $\mathrm{m}$ & $\mathrm{AEC} / \mathrm{DPV}$ & [103] \\
\hline $\mathrm{NH}_{2}$ & AGA TGG GGG TTG AGG CTA AGC CGA & - & - & $0.0037(\mathrm{~b})$ & $\mathrm{m}$ & AEC/DPV & [104] \\
\hline $\mathrm{PO}_{4}$ & AGA TGG GGG TTG AGG CTA AGC CGA & - & & $0.87(b)$ & $\mathrm{m}, \mathrm{p}, \mathrm{c}$ & $\mathrm{AEC} / \mathrm{DPV}$ & [105] \\
\hline $\mathrm{NH}_{2}$ & AGA TGG GGG TTG AGG CTA AGC CGA & - & - & $0.00042(b)$ & $\mathrm{m}, \mathrm{p}, \mathrm{c}$ & $\mathrm{AEC} / \mathrm{DPV}$ & [106] \\
\hline- & TCT GGG GGT TGA GGC TAA GCC GAC & $\left(\mathrm{CH}_{2}\right)_{6}-\mathrm{NH}_{2}$ & 78.8 & $0.00015(\mathrm{~b})$ & $\mathrm{m}$ & $\mathrm{AEC} / \mathrm{SWV}$ & {$[101,107]$} \\
\hline $\begin{array}{l}\text { apt: SH } \\
\text { cDNA: apt }\end{array}$ & $\begin{array}{l}\text { apt: TGG GGG TTG AGG CTA AGC CGA C } \\
\text { cDNA: GTC GGC TTA CGG TCA ACC CCC A }\end{array}$ & - & - & $\begin{array}{c}0.01(\mathrm{~b}) \\
\left(0.005 \times 10^{-6} \mathrm{~g} / \mathrm{L}\right)\end{array}$ & $\mathrm{m}$ & $\mathrm{AEC} / \mathrm{SWV}$ & [108] \\
\hline- & TGG GGG TTG AGG CTA AGC CG & - & - & $0.00074(\mathrm{~b})$ & $\mathrm{m}$ & AEC/DPV & [109] \\
\hline- & TGG GGG TTG AGG CTA AGC CGA C & - & - & $0.0000013(\mathrm{~b})$ & $\mathrm{m}$ & $\mathrm{AEC} / \mathrm{DPV}$ & [110] \\
\hline $\begin{array}{c}\text { apt: } \\
\mathrm{NH}_{2}-\left(\mathrm{CH}_{2}\right)_{6} \\
\text { cDNA: } \\
\mathrm{NH}_{2}-\left(\mathrm{CH}_{2}\right)_{6} \\
\end{array}$ & $\begin{array}{l}\text { apt: TGG GGG TTG AGG CTA AGC CGA C } \\
\text { cDNA: CGT TAG CCT CAA CCC }\end{array}$ & - & - & $0.00016(b)$ & $\mathrm{m}$ & $\mathrm{AEC} / \mathrm{SWV}$ & [49] \\
\hline $\mathrm{SH}$ & TGG GGG TTG AGG CTA AGC CGA & - & - & $\begin{array}{c}0.00137(\mathrm{~b}) \\
\left(0.008 \times 10^{-9} \mathrm{~g} / \mathrm{L}\right)\end{array}$ & $\mathrm{m}$ & $\mathrm{AEC} / \mathrm{DPV}$ & [111] \\
\hline apt I: SH & apt: TGG GGG TTG AGG CTA AGC CGA & & & $0.000035(b)$ & $\mathrm{m}$ & $\mathrm{AEC} / \mathrm{SWV}$ & {$[74,112]$} \\
\hline FAM & $\begin{array}{l}\text { ATA CCA GCT TAT TCA ATT AGC CCG GTA TTG AGG TCG ATC TCT } \\
\text { TAT CCT ATG GCT TGT CCC CCA TGG CTC GGT TAT ATC CAG ATA } \\
\text { GTA AGT GCA ATC T }\end{array}$ & - & 3900 & $5000(w w)$ & ww & FL & {$[113]^{2}$} \\
\hline FAM & TGG GGG TTG AGG CTA AGC CGA & - & $115 \pm 2.76$ & $0.3(b)$ & $\mathrm{m}$ & FL & {$[74,114]^{2}$} \\
\hline
\end{tabular}


Table 4. Cont.

\begin{tabular}{|c|c|c|c|c|c|c|c|}
\hline $\begin{array}{c}5^{\prime} \text { Linker } \\
\text { and Spacer }\end{array}$ & Aptamer Sequence $5^{\prime} \rightarrow 3^{\prime}$ & $\begin{array}{l}3^{\prime} \text { Linker and } \\
\text { Spacer }\end{array}$ & $\begin{array}{c}\mathrm{K}_{\mathrm{D}} \\
(\mathrm{nM})\end{array}$ & $\begin{array}{l}\text { LOD } \\
\text { (nM) }\end{array}$ & RSA & $\begin{array}{c}\text { Sensor Type/ } \\
\text { Method }\end{array}$ & $\operatorname{Ref}^{1}$ \\
\hline- & $\begin{array}{l}\text { apt: TGG GGG TTG AGG CTA AGC CGA } \\
\text { mut I: TGG AGG TTG AG CTA AGC CGA } \\
\text { mut II: TGG AGG TTG AGG CTA AGC CGA } \\
\text { mut III: TGG AGG TTG AAG CTA AAC CGA } \\
\text { mut IV: TAA AAA TTA AAA CTA AAC CAA }\end{array}$ & - & - & $0.3(b)$ & $\mathrm{m}$ & FL & {$[74,115]^{2}$} \\
\hline $\mathrm{NH}_{2}-\mathrm{C}_{6}$ & TGG GGG TTG AGG CTA AGC CGA & - & 78.8 & $10(\mathrm{~b})$ & $\mathrm{m}$ & IEC/EIS & {$[58,59]^{2}$} \\
\hline $\begin{array}{c}\text { cDNA I: } \\
\text { ferrocene- }\left(\mathrm{CH}_{2}\right)_{6} \\
\text { cDNA II: } \mathrm{SH}-\left(\mathrm{CH}_{2}\right)_{6}\end{array}$ & $\begin{array}{c}\text { apt I: TGG GGG TTG AGG CTA AGC CGA GTC ACT AT } \\
\text { cDNA I: GTG ACT CGG CTT } \\
\text { apt II: TGG GGG TTG AGG CTA AGC CGA GTC ACT AT } \\
\text { cDNA II: TAT GTG ACT CGG CTT }\end{array}$ & $\begin{array}{l}\text { apt I: }\left(\mathrm{CH}_{2}\right)_{3}-\mathrm{SH} \\
\text { apt II: }\left(\mathrm{CH}_{2}\right)_{3-}^{-} \\
\text {ferrocene }\end{array}$ & 78.8 & $1.0(\mathrm{~b})$ & lw & IEC/EIS & {$[74,116]^{2}$} \\
\hline
\end{tabular}

${ }^{1}$ When naming several references, the first always describes the realized sensor with associated LOD; aptamer sequence(s) and/or associated $\mathrm{K}_{\mathrm{D}}$ values are derived from the additional reference(s). ${ }^{2}$ Kanamycin A was investigated. 
Electrochemical aptasensors compared to optical sensors are label-free, simples, more practical and sensitive, and have attained a great deal of attention in the detection of antibiotics [72]. In order to enhance the specificity and sensitivity of the designed electrochemical aptasensors, the surface of electrodes were modified with different functional groups, nanomaterials, polymers, or nanocomposites to immobilize aptamers or standard targets.

An impedimetric disposable and portable aptasensor for the detection of kanamycin was designed by Sharma et al. [99]. Amino-functionalized kanamycin-specific aptamers were immobilized onto the surface of the working screen-printed carbon electrode (SPCE) via $\mathrm{NH}_{2}-\mathrm{COOH}$ interaction. The interaction between the aptamers and kanamycin caused an inhibition in the Faradaic response and an increase in the electron transfer resistance.

The first label-free electrochemical biosensor for kanamycin detection based on an aptamer-functionalized conducting polymer-Au nanocomposite modified disposable screen-printed electrode (SPE) was reported by Zhu et al. [100]. Many other researchers have tried to design the sensitive electrochemical sensing system for kanamycin detection. For example, Sun et al. [101] introduced an electrochemical sensor based on synergistic contributions of different nanocomposites, including chitosan-AuNPs (C-AuNPs), graphene-AuNPs (G-AuNPs), and multi-walled carbon nanotube (MWCNT)-cobalt phthalocyanine composites (MWCNT-CoPc) in order to enhance the electron transfer processes and the response speed of the aptasensor. Several nanocomposite films, e.g., graphene polyaniline/AuNPs [102,104], CNTs/ionic liquid/nanoporous platinum titanium alloy [105], CNTs/IL/graphene [106], nanoporous PtCu/graphene [107], and metal ion-doped nanoscale metal organic frameworks (MOFs) [111], have been used by other groups to improve the aptamer immobilization and fabricate a sensitive aptasensor for kanamycin.

Sometimes, in order to obtain high specificity and improve the sensitivity of aptasensors, the biocatalytic properties of enzymes are used to detect and amplify the analysis of targets with their aptamers. For example, horseradish peroxidase (HRP) [108] or glucose oxidase (GlO) [113], conjugated with AuNP-cDNA, have been used as biocatalysts for signal amplification for the detection of kanamycin.

Photoelectrochemical sensing is a novel method with high sensitivity and rapid response which combines the benefits of optical methods and electrochemical sensors [83]. Li et al. [96] developed a photoelectrochemical aptasensor for the detection of kanamycin based on the graphene-modified flour-doped $\mathrm{SnO}_{2}$ electrode. In the absence of kanamycin, the generated photocurrent was low. When kanamycin was added, it was trapped by the aptamers on the surface of the electrode. The captured molecules were oxidized by photogenerated holes. The recombination of photogenerated holes and electrons was inhibited, resulting in an amplified photocurrent.

In other reports, AuNPs-functionalized self-doped $\mathrm{TiO}_{2}$ nanotube arrays [97] and polypyrrole/ $\mathrm{CeO}_{2} / \mathrm{AuNPs}$ [98] have been used as the photoactive materials to fabricate the photoelectrochemical aptasensors for kanamycin detection.

Several research efforts have been also made toward the design of aptasensors for detection of kanamycin A based on fluorometric [114,115] and electrochemical methods [59,116]. Nikolaus and Strehlitz [113] selected DNA-aptamers specific for binding of kanamycin A by capture SELEX according to the work of Stoltenburg's team [117] and further tested in bead-based or microplate-based assays by fluorescence detection of the 5'-FAM-labelled aptamers. By the way, Robati et al. [88] authored a review about aptasensors for quantitative detection of kanamycin and kanamycin A.

In summary, around half of all developed aptamer-based biosensors for the detection of kanamycin and kanamycin A are based on electrochemical sensor principles (either impedimetric or amperometric). Moreover, a comparatively large number of fluorometric aptasensors have been developed. The most important data of the discussed aptasensors are summarized in Table 4 . The lowest LOD was reached with an amperometric aptasensor developed by Wang's team [110]. 


\subsubsection{Neomycin}

The spectrum of activity of neomycin (Figure 3c) is mainly Gram-negative bacteria, including Salmonella and Shigella. Since it is hardly absorbed after oral administration, it is particularly suitable for combating infections of the digestive tract. It is also used for superficial skin and mucous membrane infections. A disadvantage is the high ear and kidney toxicity. In general, neomycin is an oligosaccharide mixture containing the three main components $\mathrm{A}, \mathrm{B}$, and $\mathrm{C}$. Commercially available neomycin consist of about $90 \%$ neomycin B and $10 \%$ neomycin A and B [57].

In 1995 Wallis et al. [118] selected RNA-aptamers for neomycin B recognition by in vitro selection using SELEX, which was used in further studies to fabricate a fluorometric aptasensor based on AuNPs [119] and an impedimetric electrochemical aptasensor based on the immobilization of aptamers on the surface of a modified electrode with self-assembled monolayer (SAM) of mercaptopropionic acid [120].

In 2009 de-los-Santos-Alvarez et al. [121] studied how the modification of the RNA-aptamer influences the affinity of the interaction between the aptamer and neomycin B. In general, the fully 2'-O-methylization of the RNA-aptamer should prevent the degradation by endonuclease. They showed that this modification did not significantly alter the aptamer affinity towards neomycin B, but the proposed aptasensor was more sensitive towards neomycin B in comparison with other aptasensors (Table 5).

The comparison of the obtained LODs (Table 5) showed that SPR [121] is more sensitive than the optical [119] and the electrochemical [120] method.

Table 5. Aptamer sequence, dissociation constant $\left(\mathrm{K}_{\mathrm{D}}\right)$, limit of detection (LOD), real sample analysis (RSA), and realized sensor type and measuring method for neomycin B, mentioned in the corresponding references (Ref). $\mathrm{b}=$ buffer, FAM = fluorescein amidite, FIS = Faradaic impedance spectroscopy, $\mathrm{FL}=$ fluorometric, IEC $=$ impedimetric electrochemical, $\mathrm{m}=$ milk, and SPR $=$ surface plasmon resonance spectroscopy.

\begin{tabular}{|c|c|c|c|c|c|c|c|}
\hline $\begin{array}{l}5^{\prime} \text { Linker } \\
\text { and } \\
\text { Spacer }\end{array}$ & $\begin{array}{c}\text { Aptamer Sequence } \\
\qquad 5^{\prime} \rightarrow 3^{\prime}\end{array}$ & $\begin{array}{l}3^{\prime} \text { Linker } \\
\text { and } \\
\text { Spacer }\end{array}$ & $\begin{array}{c}\mathrm{K}_{\mathrm{D}} \\
(\mathrm{nM})\end{array}$ & $\begin{array}{l}\text { LOD } \\
(\mathrm{nM})\end{array}$ & RSA & $\begin{array}{l}\text { Sensor Type/ } \\
\text { Method }\end{array}$ & $\operatorname{Ref}^{1}$ \\
\hline FAM & $\begin{array}{l}\text { GGA CUG GGC GAG } \\
\text { AAG UUU AGU CC }\end{array}$ & $(\mathrm{T})_{15}-(\mathrm{A})_{12}$ & $115 \pm 25$ & $10(\mathrm{~m})$ & $\mathrm{m}$ & FL & {$[118,119]$} \\
\hline- & $\begin{array}{c}\text { (fully O-methylated) } \\
\text { GGC CUG GGC GAG } \\
\text { AAG UUU AGG CC }\end{array}$ & - & - & $<1000$ (b) & $\mathrm{m}$ & IEC/FIS & [120] \\
\hline- & $\begin{array}{c}\text { (fully O-methylated) } \\
\text { GGC CUG GGC GAG } \\
\text { AAG UUU AGG CC }\end{array}$ & - & $2500 \pm 900$ & 5 (b, SPR) & - & $\begin{array}{l}\text { IEC/FIS } \\
\text { SPR }\end{array}$ & [121] \\
\hline
\end{tabular}

\footnotetext{
${ }^{1}$ When naming several references, the first always describes the realized sensor with associated LOD; aptamer
} sequence(s) and/or associated $\mathrm{K}_{\mathrm{D}}$ values are derived from the additional reference(s). 


\subsubsection{Tobramycin}

Tobramycin (Figure 3d) is a semi-synthetic aminoglycoside antibiotic [56]. Its spectrum of activity comprises numerous Gram-negative pathogens, such as Escherichia coli, Klebsiella, Proteus, Pseudomonas, Salmonella, and Shigella, as well as Gram-positive Staphylococci and Enterococci [57]. It is therapeutically effective for infections of the respiratory and the urogenital tract, the skin, bones, the central nervous system (meningitis), and septicemia [57].

In 1995 Wang and Rando [73] selected RNA molecules that could specifically bind to the aminoglycoside antibiotic tobramycin by in vitro selection using SELEX and used in later studies [72].

Spiga et al. [122] introduced a DNA-based capture-SELEX coupled with in-stream direct-specificity monitoring via SPR. The aptamers were evaluated for their affinity to tobramycin via direct immobilization onto a SPR chip, which was used in further studies [123].

Han et al. [124] developed a magnetic bead-based SELEX to identify 37 ssDNA aptamers specific for tobramycin using a fluorescent method based on the reported principle by Ma's team [125], in which they developed a colorimetric aptasensor for the determination of tobramycin in milk and chicken eggs based on the adsorption of ssDNA aptamers on the surface of AuNPs. With the sensor of Ma et al. [125] the one reaching lowest LOD was developed (Table 6).

In order to detect drug concentration in patient samples, which are much more complex matrices than buffers, Cappi et al. [123] developed a portable, palm-sized transmission-localized SPR (TL-SPR) system for tobramycin detection. They used a setup based on aptamer-functionalized gold nanoislands (NIs) deposited on a glass slide covered with fluorine-doped tin oxide (FTO), which acts as a biosensor, and a complementary metal oxide semiconductor (CMOS) as a light detector. The sensitivity of the CMOS image sensor was matched to the localized plasmon resonance exhibited by the Au-NIs. For the first time it was shown that label-free direct detection and quantification of a small molecule can be reliably used in the complex matrix of filtered undiluted blood serum.

In an effort Gonzalez-Fernandez et al. [126] evaluated and compared the affinity and analytical characteristics of two partially and fully O-methylated modified RNA-aptamers for the design of electrochemical aptasensors for tobramycin detection in human serum. In addition to the higher endonuclease resistance, the fully O-methylated aptamer had a lower dissociation constant, as well as a lower LOD than the partially-methylated aptamer (Table 6), which was used in further experiments to develop the aptamer-based inhibition assays for detection of tobramycin $[127,128]$.

Schoukroun-Barnes et al. [128] presented a systematic study of several approaches to develop an electrochemical RNA aptamer-based biosensor for the detection of aminoglycoside antibiotics, like tobramycin. They could design a highly sensitive aptasensor for tobramycin through the optimization of the electrochemical interrogation parameters and biomolecular engineering of the RNA aptamer-sequence (Table 6).

In summary, there are just a few aptasensors developed for tobramycin detection and with the exception of one, they are based on electrochemical principles. Almost all electrochemical sensors used RNA aptamer sequences for the specific tobramycin recognition. The loweset LOD and belonging $K_{D}$ value was determined with the RNA aptamer sequence II (Table 6), mentioned by Schoukroun-Barnes et al. [128]. An even higher affinity towards tobramycin was reached by Cappi et al. [123] by using ssDNA aptamer sequence (Table 6). 
Table 6. Aptamer sequence, dissociation constant $\left(\mathrm{K}_{\mathrm{D}}\right)$, limit of detection (LOD), real sample analysis (RSA), and realized sensor type and measuring method for

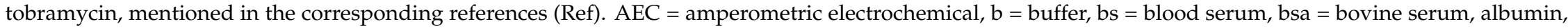
$\mathrm{CA}=$ chronoamperometry, $\mathrm{ce}=$ chicken egg, $\mathrm{CO}=$ colorimetric, $\mathrm{DPV}=$ differential pulse voltammetry, FIS = Faradaic impedance spectroscopy, $\mathrm{h}=$ honey, hs $=$ human serum, $\mathrm{IEC}=$ impedimetric electrochemical, $\mathrm{m}=$ milk, $\mathrm{MB}=$ methylene blue, $\mathrm{SPR}=$ surface plasmon resonance, and SWV = square wave voltammetry.

\begin{tabular}{|c|c|c|c|c|c|c|c|}
\hline $\begin{array}{l}5^{\prime} \text { Linker } \\
\text { and Spacer }\end{array}$ & Aptamer Sequence $5^{\prime} \rightarrow 3^{\prime}$ & $\begin{array}{l}3^{\prime} \text { Linker } \\
\text { and Spacer }\end{array}$ & $\begin{array}{l}\mathrm{K}_{\mathrm{D}} \\
(\mathrm{nM})\end{array}$ & $\begin{array}{l}\text { LOD } \\
(\mathrm{nM})\end{array}$ & RSA & $\begin{array}{l}\text { Sensor Type/ } \\
\text { Method }\end{array}$ & $\operatorname{Ref}^{1}$ \\
\hline $\mathrm{SH}$ & $\begin{array}{l}\text { TCC GTG TAT AGG TCG GGT CTC TTG CCA ACT GAT TCG TTG } \\
\text { AAA AGT ATA GCC CCG CAG GG }\end{array}$ & - & 260 & $\begin{array}{c}500(\mathrm{~b}) \\
3400(\mathrm{bs})\end{array}$ & bs & SPR & {$[122,123]$} \\
\hline - & $\begin{array}{l}\text { I: TAG GGA ATT CGT CGA CGG ATC CAT GGC ACG TTA TGC } \\
\text { GGA GGC GGT ATG ATA GCG CTA CTG CAG GTC GAC GCA } \\
\text { TGC GCC G } \\
\text { II: CGT CGA CGG ATC CAT GGC ACG TTA TGC GGT ATG ATA } \\
\text { GCG CAG GTC GAC G } \\
\text { III: CGT CGA CGG ATC CAT GGC ACG TTA TAG GTC GAC G }\end{array}$ & - & $\begin{array}{l}\text { I: } 56.9 \\
\text { II: } 46.8 \\
\text { III: } 48.4\end{array}$ & 37.9 (b) & $\mathrm{h}$ & $\mathrm{CO}$ & [124] \\
\hline- & GGG ACT TGG TTT AGG TAA TGA GTC CC & - & - & $23.3(b)$ & $\mathrm{m}, \mathrm{ce}$ & $\mathrm{CO}$ & [125] \\
\hline - & $\begin{array}{l}\text { I: (O-methylated RNA except U12 position) } \\
\text { GGC ACG AGG UUU AGC UAC ACU CGU GCC } \\
\text { II: (fully O-methylated) } \\
\text { GGC ACG AGG UUU AGC UAC ACU CGU GCC }\end{array}$ & - & $\begin{array}{l}\text { I: } 600 \\
\text { II: } 400\end{array}$ & $\begin{array}{l}\text { I: } 700 \text { (b) } \\
\text { II: } 400 \text { (b) }\end{array}$ & hs & IEC/FIS & {$[73,126]$} \\
\hline $\begin{array}{l}\text { I: SH } \\
\text { II: SH } \\
\text { III: SH }\end{array}$ & $\begin{array}{l}\text { I: GGG ACU UGG UUU AGG UAA UGA GUC CC } \\
\text { II: (fully O-methylated) } \\
\text { GGG ACU UGG UUU AGG UAA UGA GUC CC } \\
\text { III: GGG ACT TGG TTT AGG TAA TGA GTC CC }\end{array}$ & $\begin{array}{l}\text { I: NH-MB } \\
\text { II: } \\
\text { NH-MB } \\
\text { III: } \\
\text { NH-MB }\end{array}$ & $\begin{array}{c}\text { I: } 319,000 \\
\text { II: } \approx 180,000 \\
\text { III: } \approx 1,380,000\end{array}$ & - & hs & $\mathrm{AEC} / \mathrm{SWV}$ & {$[72,73]$} \\
\hline biotin & $\begin{array}{l}\text { (O-methylated except U12 position) } \\
\text { GGC ACG AGG UUU AGC UAC ACU CGU GCC }\end{array}$ & - & - & $5000(b)$ & - & $\mathrm{AEC} / \mathrm{DPV}$ & {$[73,127]$} \\
\hline fluorescein & $\begin{array}{l}\text { (O-methylated except U12 position) } \\
\text { GGC ACG AGG UUU AGC UAC ACU CGU GCC }\end{array}$ & - & - & $100(\mathrm{~b})$ & hs & $\mathrm{AEC} / \mathrm{DPV}, \mathrm{CA}$ & [129] \\
\hline $\begin{array}{l}\text { I: } \mathrm{SH}_{-} \mathrm{C}_{6} \\
\text { II: } \mathrm{SH}-\mathrm{C}_{6} \\
\text { III: } \mathrm{SH}-\mathrm{C}_{6} \\
\text { IV: } \mathrm{SH}_{-} \mathrm{C}_{6}\end{array}$ & $\begin{array}{l}\text { I: GGG ACU UGG UUU AGG UAA UGA GUC CC } \\
\text { II: ACU UGG UUU AGG UAA UGA GU } \\
\text { III: CUU GGU UUA GGU AAU GAG } \\
\text { IV: GGG ACU UGG UUU AGG UAA UGA GU }\end{array}$ & $\begin{array}{l}\text { I: MB } \\
\text { II: MB } \\
\text { III: MB } \\
\text { IV: MB }\end{array}$ & $\begin{array}{l}\text { I: } 16,000 \pm 3000 \\
\text { II: } 220 \pm 50 \\
\text { III: } 510 \pm 70 \\
\text { IV: } 2900 \pm 900 \\
\text { III: } 148,000 \pm 4000(\mathrm{~s})\end{array}$ & - & bsa & $\mathrm{AEC} / \mathrm{SWV}$ & {$[73,128]$} \\
\hline
\end{tabular}

${ }^{1}$ When naming several references, the first always describes the realized sensor with associated LOD; aptamer sequence(s) and/or associated $\mathrm{K}_{\mathrm{D}}$ values are derived from the additional reference(s). 


\subsubsection{Streptomycin}

The discovery of streptomycin (Figure 3e) from Streptomyces griseus by Selmon Waksman (1943) allowed, for the first time, a therapy of the tuberculosis pathogen Mycobacterium tuberculosis. However, due to the renal and ear-harming properties of streptomycin, other antibiotics (e.g., rifampicin) are usually used today [56]. More frequently, it is used to combat penicillin-resistant strains of Neisseria gonorrhea infections and still used for the treatment of tuberculosis [57].

The first streptomycin-specific DNA-aptamers was screened by Zhou et al. [130] by affinity magnetic bead-based SELEX. Streptomycin was detected by using a label-free AuNP-based colorimetric method.

Liu et al. [131] developed an aptamer-based colorimetric sensor for the detection of streptomycin. Different streptomycin-specific aptamer sequences were obtained by SELEX. The selected aptamer was used for all further experiments.

Based on the interesting features of AuNPs for the construction of colorimetric aptasensor, there are several reports of such biosensors for streptomycin detection [130-134].

A colorimetric and fluorescence quenching aptasensor for streptomycin detection, based on the specific aptamer and its FAM-labelled complementary strand (cDNA) and aqueous AuNPs was reported by Emrani et al. [134]. Comparisons between the pure colorimetric and the pure fluorometric method showed higher sensitivity of the aptasensor by measuring with the fluorometric one. Consequently, a variety of studies have been carried out to fabricate the high-sensitivity aptasensors for streptomycin based on the fluorometric method [135-137].

$\mathrm{Xu}$ et al. [136] developed a photoelectrochemical aptasensor for streptomycin detection based on CdTe QDs single-walled carbon nanohorns, synthesized via the one-pot method, which acted as the photoactive species. These could inhibit electron-hole pair recombination, accelerate electron transfer, and improve the photocurrent intensity.

Ghanbari and Roushani [137] introduced an impedimetric electrochemical aptasensor for the detection of streptomycin based on the immobilization of streptomycin aptamers on the surface of a graphene QDs / AuNP nanocomposite. Upon addition of streptomycin, aptamer-target complexes were formed, causing an increase of the electrochemical signal.

Yin et al. [138-140] constructed three quite similar electrochemical aptasensors for the detection of streptomycin based on the immobilization of the aptamer on the surface of modified electrodes with different nanocomposites, including MWCNTs/copper oxide (CuO)/AuNPs [138], AuNPs/magnetic MWCNTs/nanoporous PtTi alloy [139], and graphene/ $\mathrm{Fe}_{3} \mathrm{O}_{4} / \mathrm{AuNPs}$ [140]. Comparisons of the current responses of the aptasensors to streptomycin and to a mixture of streptomycin and interfering substances confirmed an excellent specificity and high sensitivity of the sensor based on an AuNPs/magnetic MWCNTs/nanoporous PtTi alloy modified electrode towards streptomycin.

Summarized, there are only a few papers dealing with aptasensing of streptomycin. According to the data of Table 7, more than half of them are are based on electrochemical measurements. The up to five orders of magnitude lower LOD than those reached with the other sensors, could be determined by Luan et al. [132] using a colorimetric assay and was followed by Yin et al. [139] with an amperometric aptasensor. 
Table 7. Aptamer sequence, dissociation constant $\left(\mathrm{K}_{\mathrm{D}}\right)$, limit of detection (LOD), real sample analysis (RSA), and realized sensor type and measuring method for streptomycin, mentioned in the corresponding references (Ref). AEC $=$ amperometric electrochemical, $b=b u f f e r, b s=b l o o d ~ s e r u m$, cap $=$ capture probe, cDNA = complementary DNA, CO = colorimetric, DPV = differential pulse voltammetry, FAM = fluorescein amidite, $\mathrm{FL}=$ fluorometric, $\mathrm{h}=$ honey, $\mathrm{IEC}=\mathrm{impedimetric}$ electrochemical, $\mathrm{m}=$ milk, $\mathrm{PEC}=$ photoelectrochemical, $\mathrm{rs}=$ rat serum, and SWV = square wave voltammetry.

\begin{tabular}{|c|c|c|c|c|c|c|c|}
\hline $\begin{array}{l}5^{\prime} \text { Linker } \\
\text { and Spacer }\end{array}$ & Aptamer Sequence $5^{\prime} \rightarrow 3^{\prime}$ & $\begin{array}{l}3^{\prime} \text { Linker } \\
\text { and Spacer }\end{array}$ & $\begin{array}{c}\mathrm{K}_{\mathrm{D}} \\
(\mathrm{nM})\end{array}$ & $\begin{array}{l}\text { LOD } \\
(\mathrm{nM})\end{array}$ & RSA & $\begin{array}{l}\text { Sensor Type/ } \\
\text { Method }\end{array}$ & $\operatorname{Ref}^{1}$ \\
\hline- & $\begin{array}{l}\text { I: GGG GTC TGG TGT TCT GCT TTG TTC TGT CGG GTC GT } \\
\text { II: TGA AGG GTC GAC TCT AGA GGC AGG TGT TCC TCA GG } \\
\text { III: AGC TTG GGT GGG GCC ACG TAG AGG TAT AGC TTG TT } \\
\text { IV: TGT GTG TTC GGT GCT GTC GGG TTG TTT CTT GGT TT }\end{array}$ & - & $\begin{array}{l}\text { I: } 199.1 \\
\text { II: } 221.3 \\
\text { III: } 272.0 \\
\text { IV: } 340.6\end{array}$ & $\begin{array}{l}\text { I: } 200(b) \\
\text { I: } 200(h)\end{array}$ & $\mathrm{h}$ & $\begin{array}{l}\mathrm{CO} / \\
\mathrm{UV}-\mathrm{VIS}\end{array}$ & [130] \\
\hline $\begin{array}{l}\text { I: FAM } \\
\text { II: FAM } \\
\text { III: FAM }\end{array}$ & $\begin{array}{l}\text { I: CCC GTT TAA AGT AGT TGA GAG TAT TCC GTT TCT TTG TGT C } \\
\text { II: GTG CGT TAT AAA CTA GTT TTG ATT CAA TGT TGG GTG TGG G } \\
\text { III: GGG CCT GTT TTG CCT TCA CGT TCT CTT CCT TGC CGT TCT G }\end{array}$ & $\begin{array}{l}\text { I: biotin } \\
\text { II: biotin } \\
\text { III: biotin }\end{array}$ & $\begin{array}{l}\text { I: } 6.07 \\
\text { II: } 8.56 \\
\text { III: } 13.14\end{array}$ & $25(b)$ & $\mathrm{m}, \mathrm{h}$ & $\mathrm{CO}$ & [131] \\
\hline $\mathrm{SH}-\left(\mathrm{CH}_{2}\right)_{6}$ & $\begin{array}{l}\text { TAG GGA ATT CGT CGACGG ATC CGG GGT CTG GTG TTC TGC } \\
\text { TTT GTT CTG TCG GGT CGTCTG CAG GTC GAC GCA TGC GCC G }\end{array}$ & - & - & $\begin{array}{c}0.0017(\mathrm{~b}) \\
\left(1 \cdot 10^{-9} \mathrm{~g} / \mathrm{L}\right)\end{array}$ & $\mathrm{m}$ & $\mathrm{CO}$ & {$[130,132]$} \\
\hline SH & $\begin{array}{l}\text { TAG GGA ATT CGT CGA CGA ATC CGG GGT CTG GTG TTC TGC } \\
\text { TTT GTT CGTB TCG GGT CGT CTG CAG GTC GAC GCA TGC GCC G }\end{array}$ & - & 199.1 & $86(b)$ & $\mathrm{m}$ & $\mathrm{CO}$ & {$[130,133]$} \\
\hline cDNA: FAM & $\begin{array}{c}\text { apt: TAG GGA ATT CGT CGA CGG ATG CGG GGT CTG GTG TTG } \\
\text { TGC TTT GTT CTG TCG GGT CGT CTG CAG GTC GAC GCA TGC } \\
\text { GCC G } \\
\text { cDNA: CGG CGC ATG CGT CGA CCT GCA GAC GAC CCG ACA } \\
\text { GAA CAA AGC AGA ACA CCA GAC CCC GGA TCC GTC GAC GAA } \\
\text { TTC CCT A }\end{array}$ & - & - & $\begin{array}{l}73.1(\mathrm{~b}, \mathrm{CO}) \\
102.4(\mathrm{bs}, \mathrm{CO}) \\
108.7(\mathrm{~m}, \mathrm{CO}) \\
47.6(\mathrm{~b}, \mathrm{FL}) \\
58.2(\mathrm{bs}, \mathrm{FL}) \\
56.2(\mathrm{~m}, \mathrm{FL})\end{array}$ & $\mathrm{m}, \mathrm{bs}$ & $\mathrm{CO}, \mathrm{FL} / \mathrm{UV}-\mathrm{VIS}$ & [134] \\
\hline- & $\begin{array}{c}\text { apt: TAG GGA ATT CGT CGA CGG ATG CGG GGT CTG GTG TTG } \\
\text { TGC TTT GTT CTG TCG GGT CGT CTG CAG GTC GAC GCA TGC } \\
\text { GCC G } \\
\text { cDNA: CGG CGCA TGC GTC GAC CTG CAG ACG ACC CGA CAG } \\
\text { AAC AAA GCA GAA CAC CAG ACC CCG GAT CCG TCG ACG AAT } \\
\text { TCC CTA }\end{array}$ & - & - & $\begin{array}{r}54.5(\mathrm{~b}) \\
71.0(\mathrm{rs}) \\
76.05(\mathrm{~m})\end{array}$ & $\mathrm{m}, \mathrm{bs}$ & $\mathrm{FL}$ & [135] \\
\hline
\end{tabular}


Table 7. Cont.

\begin{tabular}{|c|c|c|c|c|c|c|c|}
\hline $\begin{array}{l}5^{\prime} \text { Linker } \\
\text { and Spacer }\end{array}$ & Aptamer Sequence $5^{\prime} \rightarrow 3^{\prime}$ & $\begin{array}{l}3^{\prime} \text { Linker } \\
\text { and Spacer }\end{array}$ & $\begin{array}{c}\mathrm{K}_{\mathrm{D}} \\
(\mathrm{nM})\end{array}$ & $\begin{array}{l}\text { LOD } \\
(\mathrm{nM})\end{array}$ & RSA & $\begin{array}{l}\text { Sensor Type/ } \\
\text { Method }\end{array}$ & $\operatorname{Ref}^{1}$ \\
\hline- & GGG GTC TGG TGT TCT GCT TTG TTC TGT CGG GTC GT & - & - & $0.05(\mathrm{~b})$ & $\mathrm{m}$ & FL & {$[130,141]$} \\
\hline- & $\begin{array}{c}\text { apt: TAG GGA ATT CGT CGA CGG ATC CGG GGT CTG GTG TTC } \\
\text { TGC TTT GTT CTG TCG GGT CGT CTG CAG GTC GAC GCA TGC } \\
\text { GCC G } \\
\text { cDNA I: CGG CGGC ATG CGT CGA CCT GCA GAC GAC CCG ACA } \\
\text { GAA CAA AGC AGA ACA CCA GAC CCC GGA TCC GTC GAC GAA } \\
\text { TTC CCT A } \\
\text { cDNA II: CAG ACG ACC CGA CAG AAC AAA GCA GAA CAC CAG } \\
\text { ACC CCG GAT CCG TCG ACG AAT TCC CTA } \\
\text { cDNA III: GAC AGA ACA AAG CAG AAC ACC AGA CCC CGG ATC } \\
\text { CGT CGA CGA ATT CCC TA } \\
\text { cDNA IV: AGC AGA ACA CCA GAC CCC GGA TCC GTC GAC GAA } \\
\text { TTC CCT A }\end{array}$ & - & - & $94(b)$ & $\mathrm{m}, \mathrm{c}$ & FL & {$[132,142]$} \\
\hline- & $\begin{array}{l}\text { TAG GGA ATT CGT CGA CGG ATC CGG GGT CTG GTG TTC TGC } \\
\text { TTT GTT CTG TCG GGT CGT CTG CAG GTC GAC GCA TGC GCC G }\end{array}$ & $\mathrm{NH}_{2}$ & - & $0.033(b)$ & $\mathrm{h}$ & PEC & [136] \\
\hline- & $\begin{array}{l}\text { TAG GGA ATT CGT CGA CGG ATG CGG GGT CTG GTG TTG TGC } \\
\text { TTT GTT CTG TCG GGT CGT CTG CAG GTC GAC GCA TGC GCC G }\end{array}$ & $\mathrm{SH}$ & - & $\begin{array}{c}0.057 \cdot 10^{-3}(\mathrm{~b}) \\
\left(0.033 \cdot 10^{-9} \mathrm{~g} / \mathrm{L}\right)\end{array}$ & hs & IEC & [137] \\
\hline- & $\begin{array}{l}\text { TAG GGA ATT CGT CGA CGG ATG CGG GGT CTG GTG TTG TGC } \\
\text { TTT GTT CTG TCG GGT CGT CTG CAG GTC GAC GCA TGC GCC G }\end{array}$ & $\mathrm{SH}$ & - & $\begin{array}{l}11.4(\mathrm{~b}) \\
14.1(\mathrm{~m}) \\
15.3(\mathrm{rs})\end{array}$ & $\mathrm{m}, \mathrm{rs}$ & $\mathrm{AEC} / \mathrm{DPV}$ & [143] \\
\hline cap: $\mathrm{SH}-\left(\mathrm{CH}_{2}\right)_{6}$ & $\begin{array}{c}\text { apt: TAG GGA ATT CGT CGA CGG ATG CGG GGT CTG GTG TTG } \\
\text { TGC TTT GTT CTG TCG GGT CGT CTG CAG GTC GAC GCA TGC } \\
\text { GCC G } \\
\text { cap: GGT GTT GGT GTT } \\
\text { cDNA I: GAC AGA ACA AAG CAG AAC ACC A } \\
\text { cDNA II: TTC TGT CTC TCG }\end{array}$ & cDNA II: biotin & - & $10(b)$ & $\mathrm{m}$ & AEC/SWV & [41] \\
\hline- & $\begin{array}{l}\text { TAG GGA ATT CGT CGA CGG ATG CGG GGT CTG GTG TTG TGC } \\
\text { TTT GTT CTG TCG GGT CGT CTG CAG GTC GAC GCA TGC GCC G } \\
\end{array}$ & $\mathrm{SH}$ & - & $0.036(b)$ & $\mathrm{m}, \mathrm{h}$ & AEC/DPV & [138] \\
\hline $\mathrm{NH}_{2}$ & $\begin{array}{l}\text { TAG GGA ATT CGT CGA CGG ATG CGG GGT CTG GTG TTG TGC } \\
\text { TTT GTT CTG TCG GGT CGT CTG CAG GTC GAC GCA TGC GCC G }\end{array}$ & - & & $0.0078(b)$ & $\mathrm{m}$ & $\mathrm{AEC} / \mathrm{DPV}$ & [139] \\
\hline- & $\begin{array}{l}\text { TAG GGA ATT CGT CGA CGG ATG CGG GGT CTG GTG TTG TGC } \\
\text { TTT GTT CTG TCG GGT CGT CTG CAG GTC GAC GCA TGC GCC G }\end{array}$ & $\mathrm{SH}$ & - & $0.028(b)$ & $\mathrm{m}$ & $\mathrm{AEC} / \mathrm{DPV}$ & [140] \\
\hline
\end{tabular}

${ }^{1}$ When naming several references, the first always describes the realized sensor with associated LOD; aptamer sequence(s) and/or associated $\mathrm{K}_{\mathrm{D}}$ values are derived from the additional reference(s). 


\subsection{Anthracyclines}

Anthracyclines inhibit the replication of DNA by intercalation and inhibition of topoisomerases. They are used clinically for the treatment of tumors, but they can cause heart damage in the long-term medication [144]]. The basic structure, which all anthracyclines exhibit, is marked in red in Figure 4.<smiles>CC(=O)C1(O)Cc2c(O)c3c(c(O)c2C(OC2CC(N)C(O)C(C)O2)C1)C(=O)c1cccc(OO)c1C3=O</smiles>

Figure 4. Chemical structure of daunomycin. The basic structure of the anthracyclines is marked in red.

\section{Daunomycin}

Daunomycin (Figure 4), the first discovered anthracycline, produced naturally by Streptomyces peucetius, acts as an intercalator whereat the intercalation between DNA bases leads to a local structural change in the DNA and, thus, to an inhibition of DNA replication and transcription [145]. Therefore, daunomycin has a growth inhibitory effect on Gram-positive bacteria and fungi. Moreover, an antiviral effect by inhibiting viral DNA replication in the host cell was obtained. In 1963 an antileukemic activity was discovered [57]. Nowadays daunomycin is widely used for the treatment of breast tumors, lymphocytic and myeloid leukemia [146].

In 2008 Wochner et al. [147] selected ssDNA aptamers, specific for daunomycin and tetracycline, which were used in further studies for the fabrication of an aptasensor [148].

In the work of He et al. [146] a colorimetric aptasensor for daunomycin detection based on resonance scattering is described. A fluorescence spectrophotometer was used to record the resonance scattering intensity.

Chandra et al. [148] developed an electrochemical biosensor for daunomycin using the co-immobilization of the specific aptamers and phosphatidylserine on Au nanoparticle-deposited conducting polymer, which exhibited a higher sensitivity than the others (Table 8). 
Table 8. Aptamer sequence, dissociation constant $\left(\mathrm{K}_{\mathrm{D}}\right)$, limit of detection (LOD), real sample analysis (RSA), and realized sensor type and measuring method daunomycin in the corresponding references (Ref). AEC = amperometric electrochemical, $\mathrm{b}=$ buffer, $\mathrm{CO}=$ colorimetric, DPV $=$ differential pulse voltammetry, ELAA $=$ enzyme-linked aptamer assay, $\mathrm{FL}=$ fluorometric, hu = human urine, and SPR = surface plasmon resonance.

\begin{tabular}{|c|c|c|c|c|c|c|c|}
\hline $\begin{array}{l}5^{\prime} \text { Linker } \\
\text { and Spacer }\end{array}$ & Aptamer Sequence $5^{\prime} \rightarrow 3^{\prime}$ & $\begin{array}{l}3^{\prime} \text { Linker } \\
\text { and Spacer }\end{array}$ & $\begin{array}{c}\mathrm{K}_{\mathrm{D}} \\
(\mathrm{nM} \mathrm{M})\end{array}$ & $\begin{array}{l}\text { LOD } \\
(\mathrm{nM})\end{array}$ & RSA & $\begin{array}{l}\text { Sensor Type/ } \\
\text { Method }\end{array}$ & $\operatorname{Ref}^{1}$ \\
\hline- & $\begin{array}{l}\text { GGG AAT TCG AGC TCG GTA CCA TCT GTG } \\
\text { TAA GGG GTA AGG GGT GGG GGT GGG TAC } \\
\text { GTC TAG CTG CAG GCA TGC AAG CTT GG }\end{array}$ & - & 20 & $\begin{array}{c}15(\mathrm{~b}) \\
\left(8.4 \times 10^{-6} \mathrm{~g} / \mathrm{L}\right)\end{array}$ & - & $\begin{array}{l}\text { FL } \\
\text { ELAA } \\
\text { SPR }\end{array}$ & [147] \\
\hline - & $\begin{array}{l}\text { GGG AAT TCG AGC TCG GTA CCA TCT GTG } \\
\text { TAA GGG GTA AGG GGT GGG GGT GGG TAC } \\
\text { GTC TAG CTG CAG GCA TGC AAG CTT GG }\end{array}$ & - & 20 & $17.6(b)$ & - & $\mathrm{CO}, \mathrm{FL}$ & {$[146,147]$} \\
\hline poly-TTBA- $\mathrm{NH}_{2}$ & $\begin{array}{l}\text { GGG AAT TCG AGC TCG GTA CCA TCT GTG } \\
\text { TAA GGG GTA AGG GGT GGG GGT GGG TAC } \\
\text { GTC TAG CTG CAG GCA TGC AAG CTT GG }\end{array}$ & - & 20 & $0.052 \pm 0.002(\mathrm{~b})$ & hu & $\mathrm{AEC} / \mathrm{DPV}$ & {$[147,148]$} \\
\hline
\end{tabular}

${ }^{1}$ When naming several references, the first always describes the realized sensor with associated LOD; aptamer sequence(s) and/or associated $\mathrm{K}_{\mathrm{D}}$ values are derived from the additional reference(s). 


\subsection{Chloramphenicol}

Chloramphenicol is an antibiotic class of its own [56]. The chemical structure is shown in Figure 5 [57]. It blocks the peptidyl transferase by binding to the 50S subunits of the 70S ribosomes [56]. It was isolated in 1950 from Streptomyces venezuelae, but nowadays it is exclusively produced synthetically [56]. It acts against Gram-positive and Gram-negative pathogens, as well as against Actinomycetes, Rickettsiae, and some large viruses [57]. Due to its serious side effects, such as leukemia, aplastic anemia, and grey baby syndrome, it is only a reserve antibiotic used to treat typhoid, shigellosis, and rickettsial infections [57,149].<smiles>O=C(NC(CO)C(O)c1ccc([N+](=O)[O-])cc1)C(Cl)Cl</smiles>

Figure 5. Chemical structure of chloramphenicol.

In 2011 chloramphenicol-specific aptamers were selected and characterized by Mehta et al. [150] using the SELEX procedure, which was used in further studies for chloramphenicol detection [151,152].

Miao and colleges developed seven different aptasensing strategies for chloramphenicol detection [42,43,152-156]. Two aptasensors based on a colorimetric [152,153], one of them using electrochemiluminescence [154] and four aptasensors based on fluorometric principles [42,43,155,156].

In order to amplify the signals of colorimetric aptasensors, Miao's team utilized the enzyme-linked polymer nanotracers labeled by a double-stranded DNA (ds-DNA) antibody. The aptamer was immobilized on $\mathrm{Fe}_{3} \mathrm{O}_{4} / \mathrm{Au}$ magnetic nanoparticles as a capture probe, and an enzyme-linked polymer nanotracer was fabricated by co-immobilization of HRP-labelled AuNPs and double stranded DNA (dsDNA) antibodies as signal tags on EnVision reagent, a kit containing about 100 HRPs and some anti-IgG [152]. The proposed aptasensor showed to sensitively respond down to $0.015 \mathrm{ng} \mathrm{mL}^{-1}$ towards chloramphenicol.

Based on magnetic aptamer-enzyme co-immobilization platinum nanoprobes and exonucleaseassisted target recycling, Miao's team [153] designed a triple amplification colorimetric aptasensor with a detection limit of $0.3 \mathrm{pg} \mathrm{mL} \mathrm{mL}^{-1}$ towards chloramphenicol.

There are several reports in fluorometric aptasensors for chloramphenicol detection based on the immobilization of aptamers on different composites and using various prepared capture and signal probes [42,43,155-160]. Their analytical features are summarized in Table 9. As seen, the proposed "off-on" fluorometric aptasensor by Miao et al. [42] using vesicle QD-Au colloid composite probes, showed higher sensitivity towards chloramphenicol. They used the vesicle nanotracer as a signal probe, consisting of liposome-CdSe/ZnS QD complex labelled with SSB. Aptamer-functionalized AuNPs acted as the capture probe. The composite probe does not emit fluorescence signals, which represented the "off" state. Upon addition of chloramphenicol, the aptamer bound to it and the aptamer-target complex detached from the composite probe. The result is a fluorescence signal, which represents the "on" state.

Based on the sensor principle to develop a electrochemiluminescent aptasensor for the detection of chloramphenicol [149,161,162], a triple-amplification assay using polymer enzyme-linked nanotracers/Exonuclease-assisted target recycling method [154] and $\mathrm{TiO}_{2}$-based nanorod assay sensitized with Eu(III)-doped CdS QDs as the photoactive material [163] were designed with a detection limit of 0.034 and $0.36 \mathrm{pM}$ towards chloramphenicol, respectively. 
Like the other antibiotics, there are more reports of constructed electrochemical aptasensors for the detection of chloramphenicol [41,49,112,164-175] As shown in Table 9, the lowest LOD could be obtained using the proposed electrochemical aptasensor based on Y-shaped DNA probes [174]. These probe-based metal ions encoded the nanoscale metal-organic frameworks (NMOF) as a substrate, and a circular strand-replacement DNA polymerization (CSRP) target triggered the amplification strategy. The proposed strategy exhibited a high sensitivity to chloramphenicol with a detection limit of $33 \mathrm{fM}$.

\section{5. (Fluoro)Quinolones}

(Fluoro)Quinolones have a very broad spectrum of action, thus, they act against Gram-positives, Gram-negatives, Mycobacteria, Chlamydia, and anaerobes, and are just slightly toxic to humans. Their mechanism of action based on the inhibition of DNA-gyrase, which belongs to the group of topoisomerases II. Inter alia, DNA-gyrase is responsible for the derivatization of the DNA. Structurally, quinolones are derived from quinolone (marked in red in Figure 6) [56]. The efficacy of the quinolones was further enhanced by the introduction of an additional fluorine atom, resulting in a whole series of fluoroquinolones.<smiles>O=C(O)c1cn(C2CC2)c2cc(N3CCNCC3)c(F)cc2c1=O</smiles>

(a)<smiles>CCN1CCN(c2cc3c(cc2F)c(=O)c(C(=O)O)cn3C2CC2)CC1</smiles>

(c)<smiles>CN1CC2CC1CN2c1cc2c(cc1F)c(=O)c(C(=O)O)cn2C1CC1</smiles>

(b)<smiles>CC1COc2c(N3CCN(C)CC3)c(F)cc3c(=O)c(C(=O)O)cn1c23</smiles>

(d)

Figure 6. Chemical structure of: (a) ciprofloxacin; (b) danofloxacin; (c) enrofloxacin; and (d) ofloxacin. The structure of quinolone is marked in red. 
Table 9. Aptamer sequence, dissociation constant $\left(\mathrm{K}_{\mathrm{D}}\right)$, limit of detection (LOD), real sample analysis (RSA), and realized sensor type and measuring method for chloramphenicol, mentioned in the corresponding references (Ref). AEC $=$ amperometric electrochemical, apt $=a p t a m e r, b=b u f f e r, c a p=c a p t u r e ~ p r o b e, c D N A$ $=$ complementary DNA, $\mathrm{CO}=$ colorimetric, $\mathrm{d}=$ drugs, $\mathrm{DPV}=$ differential pulse voltammetry, $\mathrm{ECL}=$ electrochemiluminescent, EIS = electrochemical impedance spectrometry, $\mathrm{f}=$ fish, $\mathrm{FL}=$ fluorometric, $\mathrm{h}=$ honey, $\mathrm{hs}=$ human serum, $\mathrm{IEC}=$ impedimetric electrochemical, $\mathrm{LSV}=$ linear sweep voltammetry, $\mathrm{m}=\mathrm{milk}, \mathrm{PEC}=$ photoelectrochemical, $\mathrm{p}=$ pork, $\mathrm{rs}=$ rat serum, $\mathrm{SPR}=$ surface plasmon resonance, $\mathrm{u}=$ urine, and $\mathrm{w}=$ water.

\begin{tabular}{|c|c|c|c|c|c|c|c|}
\hline $\begin{array}{l}5^{\prime} \text { Linker } \\
\text { and Spacer }\end{array}$ & Aptamer Sequence $5^{\prime} \rightarrow 3^{\prime}$ & $\begin{array}{c}3^{\prime} \text { Linker } \\
\text { and Spacer }\end{array}$ & $\begin{array}{c}\mathrm{K}_{\mathrm{D}} \\
(\mathrm{nM})\end{array}$ & $\begin{array}{l}\text { LOD } \\
\text { (nM) }\end{array}$ & RSA & $\begin{array}{c}\text { Sensor Type/ } \\
\text { Method }\end{array}$ & $\operatorname{Ref}^{1}$ \\
\hline- & $\begin{array}{c}\text { I: ACT TCA GTG AGT TGT CCC ACG GTC GGC GAG } \\
\text { TCG GTG GTA G } \\
\text { II: ACT GAG GGC ACG GAC AGG AGG GGG AGA } \\
\text { GAT GGC GTG AGG T }\end{array}$ & - & $\begin{array}{l}\text { I: } 766 \\
\text { II: } 1160\end{array}$ & - & - & FL & [150] \\
\hline $\begin{array}{l}\text { apt: } \mathrm{SH}-\left(\mathrm{CH}_{2}\right)_{6} \\
\text { cDNA: } \mathrm{SH}-\left(\mathrm{CH}_{2}\right)_{6}\end{array}$ & $\begin{array}{c}\text { apt: ACT TCA GTG AGT TGT CCC ACG GTC GGC } \\
\text { GAG TCG GTG GTA G } \\
\text { cDNA: TTT TCT ACC ACC GAC TCG C }\end{array}$ & - & 766 & $\begin{array}{c}0.062(\mathrm{~b}) \\
\left(0.02 \times 10^{-6} \mathrm{~g} / \mathrm{L}\right)\end{array}$ & $f, p$ & CO/UV-VIS & {$[150,151]$} \\
\hline $\begin{array}{c}\text { apt: }\left(\mathrm{CH}_{2}\right)_{6} \\
\text { cDNA: SH- }\left(\mathrm{CH}_{2}\right)_{6}\end{array}$ & $\begin{array}{c}\text { apt: ACT TCA GTG AGT TGT CCC ACG GTC GGC } \\
\text { GAG TCG GTG GTA G } \\
\text { cDNA: CTA CCA CCG ACT CGC CGA CCG TGG GAC } \\
\text { AAC TCA CTG AAG T }\end{array}$ & - & - & $\begin{array}{c}0.046(\mathrm{~b}) \\
\left(0.015 \times 10^{-6} \mathrm{~g} / \mathrm{L}\right)\end{array}$ & $\mathrm{m}$ & CO/UV-VIS & {$[150,152]$} \\
\hline $\begin{array}{c}\text { apt: }\left(\mathrm{CH}_{2}\right)_{6} \\
\text { cDNA: } \mathrm{SH}-\left(\mathrm{CH}_{2}\right)_{6}\end{array}$ & $\begin{array}{c}\text { apt: ACT TCA GTG AGT TGT CCC ACG GTC GGC } \\
\text { GAG TCG GTG GTA G } \\
\text { cDNA: CTA CCA CCG ACT CGCG CGA CCG TGG GAC } \\
\text { AAC TCA CTG AAG T }\end{array}$ & - & - & $\begin{array}{c}0.00093(\mathrm{~b}) \\
\left(0.3 \times 10^{-9} \mathrm{~g} / \mathrm{L}\right)\end{array}$ & $\mathrm{m}$ & CO/UV-VIS & [153] \\
\hline- & $\begin{array}{l}\text { ACT TCA GTG AGT TGT CCC ACG GTC GGC GAG } \\
\text { TCG GTG GTA G }\end{array}$ & biotin & - & $\begin{array}{l}0.451(\mathrm{~b}) \\
0.697(\mathrm{~m}) \\
0.601(\mathrm{rs})\end{array}$ & $\mathrm{m}, \mathrm{rs}$ & CO/UV-VIS & [176] \\
\hline $\mathrm{NH}_{2}-\mathrm{C}_{6}$ & $\begin{array}{l}\text { AGC AGC ACA GAG GTC AGA TGC ACT CGG ACC } \\
\text { CCA TTC TCC TTC CAT CCC TCA TCC GTC CAC CCT } \\
\text { ATG CGT GCT ACC GTG AA }\end{array}$ & - & - & $\begin{array}{r}0.098(\mathrm{~b}) \\
0.761(\mathrm{~m})\end{array}$ & $\mathrm{m}$ & FL & [160] \\
\hline $\begin{array}{l}\text { apt: biotin } \\
\text { cDNA: } \mathrm{NH}_{2}\end{array}$ & $\begin{array}{l}\text { apt: AGC AGC ACA GAG GTC AGA TGA CTT CAG } \\
\text { TGA GTT GTC CCA CGG TCG GCG AGT CGG TGG } \\
\text { TAG CCT ATG CGT GCT ACC GTG AA } \\
\text { cDNA: CGA CCG TGG GAC AAC TCA }\end{array}$ & - & - & $\begin{array}{c}0.031(\mathrm{~b}) \\
\left(0.01 \times 10^{-6} \mathrm{~g} / \mathrm{L}\right)\end{array}$ & $\mathrm{m}$ & FL & [157] \\
\hline $\begin{array}{c}\text { apt: }\left(\mathrm{CH}_{2}\right)_{6} \\
\text { cDNA: } \mathrm{SH}-\left(\mathrm{CH}_{2}\right)_{6}\end{array}$ & $\begin{array}{c}\text { apt: ACT TCA GTG AGT TGT CCC ACG GTC GGC } \\
\text { GAG TCG GTG GTA G } \\
\text { cDNA: CTA CCA CCG ACT CGC CGA CCG TGG GAC } \\
\text { AAC TCA CTG AAG T }\end{array}$ & - & - & $\begin{array}{l}0.0006(b) \\
\left(0.0002 \times 10^{-6}\right. \\
\mathrm{g} / \mathrm{L})\end{array}$ & $\mathrm{f}$ & FL & {$[42,150]$} \\
\hline
\end{tabular}


Table 9. Cont

\begin{tabular}{|c|c|c|c|c|c|c|c|}
\hline $\begin{array}{l}5^{\prime} \text { Linker } \\
\text { and Spacer }\end{array}$ & Aptamer Sequence $5^{\prime} \rightarrow 3^{\prime}$ & $\begin{array}{l}3^{\prime} \text { Linker } \\
\text { and Spacer }\end{array}$ & $\begin{array}{c}\mathrm{K}_{\mathrm{D}} \\
(\mathrm{nM})\end{array}$ & $\begin{array}{l}\text { LOD } \\
(\mathrm{nM})\end{array}$ & RSA & $\begin{array}{l}\text { Sensor Type/ } \\
\text { Method }\end{array}$ & $\operatorname{Ref}^{1}$ \\
\hline $\begin{array}{l}\text { apt: }\left(\mathrm{CH}_{2}\right)_{6} \\
\text { cDNA: } \mathrm{SH}-\left(\mathrm{CH}_{2}\right)_{6} \\
\text { G-quadruplex: } \\
\text { SH- }\left(\mathrm{CH}_{2}\right)_{6}\end{array}$ & $\begin{array}{c}\text { apt: ACT TCA GTG AGT TGT CCC ACG GTC GGC } \\
\text { GAG TCG GTG GTA G } \\
\text { cDNA: CTA CCA CCG ACT CGC CGA CCG TGG GAC } \\
\text { AAC TCA CTG AAG T } \\
\text { G-quadruplex: GGG TAG GGC GGG AA }\end{array}$ & - & - & $\begin{array}{l}0.0015(\mathrm{~b}) \\
\left(0.0005 \times 10^{-6}\right. \\
\mathrm{g} / \mathrm{L})\end{array}$ & $\mathrm{m}$ & $\mathrm{FL}$ & {$[150,156]$} \\
\hline$\left(\mathrm{CH}_{2}\right)_{6}$ & $\begin{array}{l}\text { ACT TCA GTG AGT TGT CCC ACG GTC GGC GAG } \\
\text { TCG GTG GTA G }\end{array}$ & - & - & $0.001(b)$ & $\mathrm{f}$ & $\mathrm{FL}$ & {$[150,155]$} \\
\hline apt: $\mathrm{SH}-\left(\mathrm{CH}_{2}\right)_{6}$ & $\begin{array}{c}\text { apt: ACT TCA GTG AGT TGT CCC ACG GTC GGC } \\
\text { GAG TCG GTG GTA G } \\
\text { cDNA: CTA CCA CCG ACT CGC }\end{array}$ & - & - & $0.0003(b)$ & $\mathrm{m}$ & FL & {$[43,150]$} \\
\hline- & $\begin{array}{c}\text { apt: CAA TAA GCG ATG CGC CCT CGC CTG GGG } \\
\text { GCC TAG TCC TCT CCT ATG CGT GCT ACC GTG AA } \\
\text { cDNAI: TCG CTT ATT GAA AAA AAA AA } \\
\text { cDNAII: CAT CGC TTA TTG AAA AAA AAA A } \\
\text { cDNAIII: CGC ATC GCT TAT TGA AAA AAA AAA }\end{array}$ & $\begin{array}{l}\text { cDNAI: biotin } \\
\text { cDNAII: biotin } \\
\text { cDNAIII: biotin }\end{array}$ & 32.24 & 0.31 (b) & $\mathrm{m}$ & FL & [158] \\
\hline $\mathrm{SH}-\left(\mathrm{CH}_{2}\right)_{6}$ & $\begin{array}{l}\text { ACT TCA GTG AGT TGT CCC ACG GTC GGC GAG } \\
\text { TCG GTG GTA G }\end{array}$ & - & 766 & $\begin{array}{c}0.093(\mathrm{~b}) \\
\left(0.003 \times 10^{-6} \mathrm{~g} / \mathrm{L}\right)\end{array}$ & $\mathrm{m}$ & FL & {$[150,159]$} \\
\hline cDNA: $\mathrm{SH}-\left(\mathrm{CH}_{2}\right)_{6}$ & $\begin{array}{c}\text { apt: ACT TCA GTG AGT TGT CCC ACG GTC GGC } \\
\text { GAG TCG GTG GTA G } \\
\text { cDNA: TTT TTC TAC CAC CGA CTC }\end{array}$ & apt: $\mathrm{COOH}$ & - & $0.07(b)$ & - & ECL & {$[161,167]$} \\
\hline $\begin{array}{c}\text { apt: biotin } \\
\text { cDNA: } \mathrm{SH}-\left(\mathrm{CH}_{2}\right)_{6}\end{array}$ & $\begin{array}{c}\text { apt: TTT TTA GCA GCA CAG AGG TCA GAT GAC TTC } \\
\text { AGT GAG TTG TCC CAC GGT CGG CGA GTC GGT } \\
\text { AGC CTA TGC GTG CTA CCG TGA A } \\
\text { cDNA: CAC GCA TAG GCT ACC A }\end{array}$ & - & - & $\begin{array}{c}0.031(\mathrm{~b}) \\
\left(0.01 \times 10^{-6} \mathrm{~g} / \mathrm{L}\right) \\
3.094(\mathrm{~m}) \\
\left(1.0 \times 10^{-6} \mathrm{~g} / \mathrm{L}\right)\end{array}$ & $\mathrm{m}$ & ECL & {$[149,150]$} \\
\hline cDNA: $\mathrm{SH}-\left(\mathrm{CH}_{2}\right)_{6}$ & $\begin{array}{l}\text { apt: ACT TCA GTG AGT TGT CCC ACG GTC GGC } \\
\text { GAG TCG GTG GTA G } \\
\text { cDNA: CTA CCA CCG ACT C }\end{array}$ & apt: $\left(\mathrm{CH}_{2}\right)_{6}-\mathrm{NH}_{2}$ & - & $0.03(b)$ & $\mathrm{f}$ & ECL & {$[162,167]$} \\
\hline apt: $\left(\mathrm{CH}_{2}\right)_{6}$ & $\begin{array}{c}\text { apt: ACT TCA GTG AGT TGT CCC ACG GTC GGC } \\
\text { GAG TCG GTG GTA G } \\
\text { cDNA: CTC GCC GAC CGT GGG ACA ACT CAC } \\
\text { TGA AGT }\end{array}$ & - & - & 0.000034 (b) & $\mathrm{f}$ & ECL/SPR & {$[150,154]$} \\
\hline- & $\begin{array}{l}\text { ACT TCA GTG AGT TGT CCC ACG GTC GGC GAG } \\
\text { TCG GTG GTA G }\end{array}$ & - & - & $3.1(b)$ & d & PEC & [177] \\
\hline
\end{tabular}


Table 9. Cont

\begin{tabular}{|c|c|c|c|c|c|c|c|}
\hline $\begin{array}{l}5^{\prime} \text { Linker } \\
\text { and Spacer }\end{array}$ & Aptamer Sequence $5^{\prime} \rightarrow 3^{\prime}$ & $\begin{array}{c}3^{\prime} \text { Linker } \\
\text { and Spacer }\end{array}$ & $\begin{array}{c}\mathrm{K}_{\mathrm{D}} \\
(\mathrm{nM})\end{array}$ & $\begin{array}{l}\text { LOD } \\
\text { (nM) }\end{array}$ & RSA & $\begin{array}{l}\text { Sensor Type/ } \\
\text { Method }\end{array}$ & $\operatorname{Ref}^{1}$ \\
\hline $\mathrm{NH}_{2}$ & $\begin{array}{l}\text { ACT TCA GTG AGT TGT CCC ACG GTC GGC GAG } \\
\text { TCG GTG GTA G }\end{array}$ & - & - & $0.00036(b)$ & $\mathrm{m}$ & PEC & [163] \\
\hline $\mathrm{SH}-\left(\mathrm{CH}_{2}\right)_{6}$ & $\begin{array}{c}\text { AGC AGC ACA GAG GTC AGA TGA CTG AGG GCA } \\
\text { CGG ACA GGA GGG GGA GAG ATG GCG TGA GGT } \\
\text { CCT ATG CGT GCT ACC GTG AA }\end{array}$ & - & - & $1.76(b)$ & - & IEC/EIS & {$[150,178]$} \\
\hline $\mathrm{SH}-\left(\mathrm{CH}_{2}\right)_{6}$ & $\begin{array}{l}\text { AGC AGC ACA GAG GTC AGA TGA CTG AGG GCA } \\
\text { CGG ACA GGA GGG GGA GAG ATG GCG TGA GGT } \\
\text { CCT ATG CGT GCT ACC GTG AA }\end{array}$ & - & - & $1000(b)$ & - & $\mathrm{AEC} / \mathrm{SWV}$ & {$[150,164]$} \\
\hline $\mathrm{SH}-\left(\mathrm{CH}_{2}\right)_{6}$ & $\begin{array}{l}\text { AGC AGC ACA GAG GTC AGA TGA CTG AGG GCA } \\
\text { CGG ACA GGA GGG GGA GAG ATG GCG TGA GGT } \\
\text { CCT ATG CGT GCT ACC GTG AA }\end{array}$ & - & 766 & $\begin{array}{l}1.6(\mathrm{~b}) \\
1.6(\mathrm{~m})\end{array}$ & $\mathrm{w}, \mathrm{m}$ & $\mathrm{AEC} / \mathrm{SWV}$ & {$[150,165]$} \\
\hline $\begin{array}{l}\text { apt: } \mathrm{SH}-\left(\mathrm{CH}_{2}\right)_{6} \\
\text { cDNA: biotin }\end{array}$ & $\begin{array}{c}\text { apt: TTT TTA GCA GCA CAG AGG TCA GAT GAC TTC } \\
\text { AGT GAG TTG TCC CAC GGT CGG CGA GTC GGT } \\
\text { GGT AGC CTA TGC GTG CTA CCG TGA A } \\
\text { cDNA: TTT TCT ACC ACC GAC TCG C }\end{array}$ & - & - & $0.29(b)$ & $\mathrm{h}$ & AEC/DPV & {$[150,166]$} \\
\hline $\mathrm{NH}_{2}$ & $\begin{array}{l}\text { ACT TCA GTG AGT TGT CCC ACG GTC GGC GAG } \\
\text { TCG GTG GTA G }\end{array}$ & - & - & $0.02(b)$ & $\mathrm{u}, \mathrm{d}$ & $\mathrm{AEC} / \mathrm{SWV}$ & {$[150,167]$} \\
\hline $\mathrm{SH}-\left(\mathrm{CH}_{2}\right)_{6}$ & $\begin{array}{l}\text { AGC AGC ACA GAG GTC AGA TGA CTT CAG TGA } \\
\text { GTT GTC CCA CGG TCG GCG AGT CGG TGG TAG } \\
\text { CCT ATG CGT GCT ACC GTG AA }\end{array}$ & - & - & $4.0(b)$ & hs & $\mathrm{AEC} / \mathrm{SWV}$ & [168] \\
\hline $\mathrm{SH}-\left(\mathrm{CH}_{2}\right)_{6}$ & $\begin{array}{l}\text { AGC AGC ACA GAG GTC AGA TGA CTG AGG GCA } \\
\text { CGG ACA GGA GGG CAT GGA GAG ATG GCG }\end{array}$ & - & 766 & $0.183(b)$ & $\mathrm{m}$ & AEC/DPV & {$[150,169]$} \\
\hline $\mathrm{NH}_{2}$ & $\begin{array}{l}\text { ACT TCA GTG AGT TGT CCC ACG GTC GGC GAG } \\
\text { TCG GTG GTA G }\end{array}$ & - & - & $\begin{array}{l}0.000011(b) \\
0.000014(\mathrm{u})\end{array}$ & d & $\mathrm{AEC} / \mathrm{SWV}$ & {$[167,170]$} \\
\hline $\begin{array}{l}\text { apt: } \mathrm{SH}-\left(\mathrm{CH}_{2}\right)_{6} \\
\text { cDNA: } \mathrm{NH}_{2}-\left(\mathrm{CH}_{2}\right)_{6}\end{array}$ & $\begin{array}{c}\text { apt: ACT TCA GTG AGT TGT CCC ACG GTC GGC } \\
\text { GAG TCG GTG GTA G } \\
\text { cDNA: ACC ACC GAC TCG CCG }\end{array}$ & - & & $\begin{array}{c}0.0009(\mathrm{~b}) \\
\left(0.3 \times 10^{-9} \mathrm{~g} / \mathrm{L}\right)\end{array}$ & $\mathrm{f}$ & $\mathrm{AEC} / \mathrm{SWV}$ & [171] \\
\hline $\mathrm{SH}-\left(\mathrm{CH}_{2}\right)_{6}$ & $\begin{array}{c}\text { AGC AGC ACA GAG GTC AGA TGA CTT CAG TGA } \\
\text { GTT GTC CCA CGG TCG GCG AGT CGG TGG TAG } \\
\text { CCT ATG CGT GCT ACC GTG AA }\end{array}$ & - & - & $4.0(\mathrm{~b})$ & hs & AEC/DPV & [172] \\
\hline
\end{tabular}


Table 9. Cont.

\begin{tabular}{|c|c|c|c|c|c|c|c|}
\hline $\begin{array}{l}5^{\prime} \text { Linker } \\
\text { and Spacer }\end{array}$ & Aptamer Sequence $5^{\prime} \rightarrow 3^{\prime}$ & $\begin{array}{l}3^{\prime} \text { Linker } \\
\text { and Spacer }\end{array}$ & $\begin{array}{c}\mathrm{K}_{\mathrm{D}} \\
(\mathrm{nM})\end{array}$ & $\begin{array}{l}\text { LOD } \\
\text { (nM) }\end{array}$ & RSA & $\begin{array}{l}\text { Sensor Type/ } \\
\text { Method }\end{array}$ & $\operatorname{Ref}^{1}$ \\
\hline $\begin{array}{l}\text { cDNA I: } \mathrm{SH}-\left(\mathrm{CH}_{2}\right)_{6} \\
\text { cDNA II: } \mathrm{NH}_{2}-\left(\mathrm{CH}_{2}\right)_{6}\end{array}$ & $\begin{array}{c}\text { apt: ACT TCA GTG AGT TGT CCC ACG GTC GGC } \\
\text { GAG TCG GTG GTA } \\
\text { cDNA I: ACA CAA GGG GGC CAC CAC AA } \\
\text { cDNA II: TTG TGG TGG CCC CCT TGT GT }\end{array}$ & cDNA I: $\left(\mathrm{CH}_{2}\right)_{6}$ & - & $\begin{array}{c}0.46(\mathrm{~b}) \\
\left(0.15 \times 10^{-6} \mathrm{~g} / \mathrm{L}\right)\end{array}$ & $\mathrm{m}$ & $\mathrm{AEC} / \mathrm{SWV}$ & [173] \\
\hline cap: $\mathrm{SH}-\left(\mathrm{CH}_{2}\right)_{6}$ & $\begin{array}{c}\text { apt: AGC AGC ACA GAG GTC AGA TGA CTT CAG } \\
\text { TGA GTT GTC CCA CGG TCG GCG AGT CGG TGG } \\
\text { TAG CCT ATG CGT GCT ACC GTG AA } \\
\text { cap: GAG GAT TCA GTG A } \\
\text { cDNA I: CCG ACC GTG GGA CAA CTC AGT GAA } \\
\text { cDNA II: ACG GTC GGT TAC A }\end{array}$ & cDNA II: biotin & - & $5(b)$ & $\mathrm{m}$ & AEC/SWV & [41] \\
\hline $\begin{array}{l}\text { apt: } \mathrm{NH}_{2}-\left(\mathrm{CH}_{2}\right)_{6} \\
\text { cDNA: } \mathrm{NH}_{2}-\left(\mathrm{CH}_{2}\right)_{6}\end{array}$ & $\begin{array}{l}\text { apt: ACT TCA GTG AGT TGT CCC ACG GTC GGC } \\
\text { GAG TCG GTG GTA G } \\
\text { cDNA: ACC GAC TCG CCG ACC }\end{array}$ & - & - & $0.00019(b)$ & $\mathrm{m}$ & AEC/SWV & [49] \\
\hline $\begin{array}{l}\text { cDNA I: } \mathrm{NH}_{2}-\left(\mathrm{CH}_{2}\right)_{6} \\
\text { cDNA II: } \mathrm{SH}-\left(\mathrm{CH}_{2}\right)_{6}\end{array}$ & $\begin{array}{c}\text { apt: ACT TCA GTG AGT TGT CCCACG GTC GGC GAG } \\
\text { TCG GTG GTA GCC TAT GCA GTT T } \\
\text { cDNA I: TTT CGC TGT GAC } \\
\text { CTA CCA CCG ACT GC } \\
\text { cDNA II: TTT GTG CAT AGG GTC ACA G }\end{array}$ & - & - & $0.0000033(b)$ & $\mathrm{m}$ & $\mathrm{AEC} / \mathrm{SWV}$ & [174] \\
\hline $\mathrm{SH}-\left(\mathrm{CH}_{2}\right)_{6}$ & $\begin{array}{l}\text { ACT TCA GTG AGT TGT CCC ACG GTC GGC GAG } \\
\text { TCG GTG GTA G }\end{array}$ & - & - & $2.0(b)$ & $\mathrm{m}$ & AEC/LSV & [175] \\
\hline apt: SH & $\begin{array}{l}\text { apt: AGC AGC ACA GAG GTC AGA TGA CTG AGG } \\
\text { GCA CGG ACA GGA GGG CAT GGA GAG ATG GCG }\end{array}$ & & - & $0.000021(b)$ & $\mathrm{m}$ & $\mathrm{AEC} / \mathrm{SWV}$ & {$[112,150]$} \\
\hline
\end{tabular}

${ }^{1}$ When naming several references, the first always describes the realized sensor with associated LOD; aptamer sequence(s) and/or associated $K_{D}$ values are derived from the additional reference(s). 


\subsubsection{Ciprofloxacin}

Ciprofloxacin (Figure 6a), a second-generation fluoroquinolone, which acts against Bacillus anthracis, the causative agent of anthrax, and is one of the most used quinolones nowadays $[5,56]$.

There are just two reports of aptasensors for ciprofloxacin detection. In 2017 Lavee et al. [179] developed for the first time a colorimetric aptamer-based assay for the determination of ciprofloxacin using AuNPs. In another study an electrochemical aptasensor for ultrasensitive detection of fluoroquinolones, especially ciprofloxacin, based on a single-stranded DNA-binding protein, was presented [180].

The electrochemical aptasensor [180] possess 1.5-fold lower LOD than the colorimetric one [179] (Table 10).

\subsubsection{Danofloxacin}

Danofloxacin (Figure 6b) acts against Gram-positive and Gram-negative bacteria and is often used for the treatment of respiratory diseases of cattle and pigs [181]. It is exclusively used in animal husbandry, not least because of its toxicity to humans [181].

By the application of SELEX, Han et al. [181] selected specific and high-affinity RNA aptamers with 2'-fluoro-2'-deoxyribonucleotide-modified pyrimidine nucleotides bound to danofloxacin. As a consequence, they employed an optical aptasensor for the detection of danofloxacin in buffer. The most important data of the discussed aptasensor are given in Table 11.

There are no other reports about investigations for danofloxacin detection by an aptasensor mentioned in the literature.

\subsubsection{Enrofloxacin}

Enrofloxacin (Figure 6c) is a high-potency antibacterial agent which is widely employed for disease prevention and therapy in poultry and livestock breeding and aquaculture practice [182,183].

For the detection of enrofloxacin, Liu et al. [182] designed a fluorometric aptasensor based on the immobilization of aptamers on the surface of $\mathrm{Yb}$, Er ion-pair doped magnetic $\mathrm{Fe}_{3} \mathrm{O}_{4}$ UCNPs and amino-functionalized silica-modified $\left(\mathrm{NH}_{2}\right.$-Si) UCNPs.

Moreover, Liu's group [183] developed a fluorometric "double recognition" aptasensor for the detection of enrofloxacin by integrating two antibiotic recognition elements, including aptamers and fully-synthetic molecularly-imprinted polymers (MIPs) The LOD of the proposed aptasensor was about five times lower than the previously presented "simple" one [182] (Table 12), which is presumably related to the improved recognition ability of the sensor by the use of aptamers in combination with MIPs.

The two described are the only papers which deal with the aptamer-based detection of enrofloxacin, so there exists potential for further research.

\subsubsection{Ofloxacin}

Ofloxacin (Figure 6d) is a second-generation fluoroquinolone, used in bacterial infections of the respiratory tract and the gastrointestinal tract [184].

Reinemann et al. [185] searched for aptamer sequences specific for ofloxacin and, furthermore, determined the dissociation constant $\left(\mathrm{K}_{\mathrm{D}}\right.$ value) of the aptamer-target system.

In 2017 Pilehvar et al. [184] developed a rapid, stable, and sensitive label-free electrochemical aptasensor for ofloxacin detection based on the immobilization of the specific aptamer on AuNPs. The most important data of the two aptasensors are summarized in Table 13.

There are no more reports about aptasensors for ofloxacin detection. 
Table 10. Aptamer sequence, dissociation constant $\left(\mathrm{K}_{\mathrm{D}}\right)$, limit of detection (LOD), real sample analysis (RSA), and realized sensor type and measuring method for ciprofloxacin, mentioned in the corresponding references (Ref). AEC $=$ amperometric electrochemical, $b=$ buffer, $c D N A=$ complementary DNA, CO $=$ colorimetric, $\mathrm{DPV}=$ differential pulse voltammetry, hs = human serum, $\mathrm{m}=$ milk, and sw $=$ spiked water.

\begin{tabular}{|c|c|c|c|c|c|c|c|}
\hline $\begin{array}{c}5^{\prime} \text { Linker } \\
\text { and Spacer }\end{array}$ & Aptamer Sequence $5^{\prime} \rightarrow 3^{\prime}$ & $\begin{array}{c}3^{\prime} \text { Linker } \\
\text { and Spacer }\end{array}$ & $\begin{array}{l}\mathrm{K}_{\mathrm{D}} \\
(\mathrm{nM})\end{array}$ & $\begin{array}{l}\text { LOD } \\
\text { (nM) }\end{array}$ & RSA & $\begin{array}{c}\text { Sensor Type/ } \\
\text { Method }\end{array}$ & $\operatorname{Ref}^{1}$ \\
\hline cDNA II: SH & $\begin{array}{c}\text { apt: ATA CCA GCT TAT TCA ATT GCA GGG TAT CTG AGG CTT } \\
\text { GAT CTA CTA AAT GTC GTG GGG CAT TGC TAT TGG CGT TGA } \\
\text { TAC GTA CAA TCG TAA TCA GTT AG } \\
\text { CDNA I: TTG AAT AAG CTG GTA TAA ACC } \\
\text { cDNA II: AAA CCA CCT CCG AAT CCC AAG CCA CCG CCG CTA } \\
\text { ACT GAT TAC GAT TGT }\end{array}$ & cDNA I: SH & - & $\begin{array}{l}1.3(\mathrm{sw}) \\
2.6(\mathrm{~s}) \\
3.2(\mathrm{~m})\end{array}$ & $\begin{array}{l}\mathrm{sw}, \\
\mathrm{hs} \\
\mathrm{m}\end{array}$ & $\mathrm{CO}$ & {$[179,185]$} \\
\hline $\mathrm{SH}$ & $\begin{array}{c}\text { ATA CCA GCT TAT TCA ATT GCA GGG TAT CTG AGG CTT GAT } \\
\text { CTA CTA AAT GTC GTG GGG CAT TGC TAT TGG CGT TGA TAC } \\
\text { GTA CAA TCG TAA TCA GTT AG }\end{array}$ & - & - & $0.263(b)$ & $\begin{array}{l}\mathrm{m}, \\
\mathrm{hs}\end{array}$ & $\mathrm{AEC} / \mathrm{DPV}$ & [180] \\
\hline
\end{tabular}

${ }^{1}$ When naming several references, the first always describes the realized sensor with associated LOD; aptamer sequence(s) and/or associated $\mathrm{K}_{\mathrm{D}}$ values are derived from the additional reference(s).

Table 11. Aptamer sequence, dissociation constant $\left(\mathrm{K}_{\mathrm{D}}\right)$, limit of detection (LOD), real sample analysis (RSA), and realized sensor type and measuring method for danofloxacin, mentioned in the corresponding references (Ref). FAM = fluorescein amidite, FL = fluorometric, and SPR = surface plasmon resonance.

\begin{tabular}{|c|c|c|c|c|c|c|c|}
\hline $\begin{array}{c}5^{\prime} \text { Linker } \\
\text { and Spacer }\end{array}$ & Aptamer Sequence $5^{\prime} \rightarrow 3^{\prime}$ & $\begin{array}{l}3^{\prime} \text { Linker } \\
\text { and Spacer }\end{array}$ & $\begin{array}{c}K_{D} \\
(n M)\end{array}$ & $\begin{array}{l}\text { LOD } \\
(\mathrm{nM})\end{array}$ & RSA & $\begin{array}{c}\text { Sensor Type/ } \\
\text { Method }\end{array}$ & $\operatorname{Ref}^{1}$ \\
\hline FAM-oligo(dT) & UCA GGC UCC UGU GAA GCA ACC GAA UGG ACU GA & $\mathrm{A}_{16}$ & $1.81 \pm 0.18$ & - & - & FL, SPR & [181] \\
\hline
\end{tabular}

additional referer 
Table 12. Aptamer sequence, dissociation constant $\left(\mathrm{K}_{\mathrm{D}}\right)$, limit of detection (LOD), real sample analysis (RSA), and realized sensor type and measuring method for enrofloxacin, mentioned in the corresponding references (Ref). apt $=$ aptamer, $b=$ buffer, $c D N A=$ complementary DNA, and FL $=$ fluorometric.

\begin{tabular}{|c|c|c|c|c|c|c|c|}
\hline $\begin{array}{l}5^{\prime} \text { Linker } \\
\text { and Spacer }\end{array}$ & Aptamer Sequence $5^{\prime} \rightarrow 3^{\prime}$ & $\begin{array}{l}3^{\prime} \text { Linker } \\
\text { and Spacer }\end{array}$ & $\begin{array}{l}\mathrm{K}_{\mathrm{D}} \\
(\mathrm{nM})\end{array}$ & $\begin{array}{l}\text { LOD } \\
\text { (nM) }\end{array}$ & RSA & $\begin{array}{l}\text { Sensor Type/ } \\
\text { Method }\end{array}$ & $\operatorname{Ref}^{1}$ \\
\hline- & $\begin{array}{c}\text { apt: CCC ATC AGG GGG CTA GGC TAA CAC GGT TCG } \\
\text { GCT CTC TGA GCC CGG GTT ATT TCA GGG GGA } \\
\text { cDNA: GTG TTA GCC TAG CCC CCT GAT }\end{array}$ & $\begin{array}{l}\text { apt: biotin } \\
\text { cDNA: biotin }\end{array}$ & - & $\begin{array}{c}0.56(\mathrm{~b}) \\
\left(0.02 \times 10^{-6} \mathrm{~g} / \mathrm{L}\right)\end{array}$ & $\mathrm{f}$ & FL & [182] \\
\hline- & $\begin{array}{l}\text { CCC ATC AGG GGG CTA GGC TAA CAC GGT TCG } \\
\text { GCT CTC TGA GCC CGG GTT ATT TCA GGG GGA }\end{array}$ & biotin & - & $\begin{array}{c}0.11(\mathrm{~b}) \\
\left(0.04 \times 10^{-6} \mathrm{~g} / \mathrm{L}\right)\end{array}$ & $\mathrm{f}$ & FL & [183] \\
\hline
\end{tabular}

${ }^{1}$ When naming several references, the first always describes the realized sensor with associated LOD; aptamer sequence(s) and/or associated $\mathrm{K}_{\mathrm{D}}$ values are derived from the additional reference(s).

Table 13. Aptamer sequence, dissociation constant $\left(\mathrm{K}_{\mathrm{D}}\right)$, limit of detection (LOD), real sample analysis (RSA), and realized sensor type and measuring method for oflofloxacin, mentioned in the corresponding references (Ref). AEC $=$ amperometric electrochemical, $b=b u f f e r, C V=c y c l i c$ voltammetry, DPV $=$ differential pulse voltammetry, $\mathrm{FL}=$ fluorometric, $\mathrm{p}=$ pork, and $\mathrm{p}=$ tap water.

\begin{tabular}{|c|c|c|c|c|c|c|c|}
\hline $\begin{array}{l}5^{\prime} \text { Linker } \\
\text { and Spacer }\end{array}$ & Aptamer Sequence $5^{\prime} \rightarrow 3^{\prime}$ & $\begin{array}{l}3^{\prime} \text { Linker } \\
\text { and Spacer }\end{array}$ & $\begin{array}{c}\mathrm{K}_{\mathrm{D}} \\
(\mathrm{nM} \mathrm{M})\end{array}$ & $\begin{array}{l}\text { LOD } \\
(\mathrm{nM})\end{array}$ & RSA & $\begin{array}{l}\text { Sensor Type/ } \\
\text { Method }\end{array}$ & $\operatorname{Ref}^{1}$ \\
\hline $\mathrm{SH}-\left(\mathrm{CH}_{2}\right)_{6}$ & $\begin{array}{l}\text { ATA CCA GCT TAT TCA ATT AGT TGT GTA TTG AGG TTT } \\
\text { GAT CTA GGC ATA GTC AAC AGA GCA CGA TCG ATC } \\
\text { TGG CTT GTT CTA CAA TCG TAA TCA GTT AG }\end{array}$ & - & 0.2 & $1.0(\mathrm{~b})$ & $\mathrm{p}, \mathrm{tp}$ & $\mathrm{AEC} / \mathrm{CV}, \mathrm{DPV}$ & {$[184,185]$} \\
\hline- & $\begin{array}{l}\text { apt I: ATA CCA GCT TAT TCA ATT CGA TGG TAA GTG } \\
\text { AGG TTC GTC CCT TTA ATA AAC TCG ATT AGG ATC } \\
\text { TCG TGA GGT GTG CTC TAC AAT CGT AAT CAG TTA G } \\
\text { apt II: ATA CCA GCT TAT TCA ATT GCA GGG TAT CTG } \\
\text { AGG CTT GAT CTA CTA AAT GTC GTG GGG CAT TGC } \\
\text { TAT TGG CGT TGA TAC GTA CAA TCG TAA TCA GTT AG } \\
\text { apt III: ATA CCA GCT TAT TCA ATT AGT TGT GTA TTG } \\
\text { AGG TTT GAT CTA GGC ATA GTC AAC AGA GCA CGA } \\
\text { TCG ATC TGG CTT GTT CTA CAA TCG TAA TCA GTT AG }\end{array}$ & - & $\begin{array}{c}\text { I: } 56.9 \pm 11.3 \\
\text { II: } 0.11 \pm 0.06 \\
\text { III: } 0.20 \pm 0.09\end{array}$ & - & - & FL & [185] \\
\hline
\end{tabular}




\subsection{Lincosamide}

Lincosamides, called acylaminopyranosides due to their chemical structure, bind to the $50 \mathrm{~S}$ subunit of the bacterial ribosomes and block the enzyme peptidyltransferase, resulting in an interrupted chain elongation during protein biosynthesis [56]. Lincosamides are frequently used in the case of staphylococcal, streptococcal, and pneumococcal infections [57]. Three representatives exist: the natural lincomycin (Figure 7) and two semi-synthetic derivates, clindamycin and pirlimycin [5]. The structure, which is common to all anthracyclines, is marked in red in Figure 7. Anthracyclines are applied especially if a penicillin allergy exists [57].<smiles>CCCC1CC(C(=O)NC(C(C)O)C2OC(SC)C(O)C(O)C2O)N(C)C1</smiles>

Figure 7. Chemical structure of lincomycin. The basic structure of the anthracyclines is marked in red.

Lincomycin was the first discovered lincosamide, isolated from Streptomyces lincolnensis in a soil sample from Lincoln (Nebraska) [5,57]. It is preferable for the treatment of bone marrow inflammation and wound and respiratory infections [57].

To the best of our knowledge, there is just one report of sensor assay for lincomycin with a dual recognition system comprising a MIP and aptamers [186]. They used the AuNP-functionalized GO nanocomposite for signal amplification, and C-dots, which were modified onto the lincomycin-specific aptamers, serving as a signal indicator and exhibiting enhanced signal intensity in the absence of lincomycin. Electrogenerated chemiluminescence resonance energy transfer was observed between Au-GO and C-dots. After the C-dots accepted the energy, they acted as a signal indicator and exhibited enhanced signal intensity in the presence of the target lincomycin. The results confirmed that the combined characteristics of the specific molecular recognition properties of aptamers and MIPs enhance the recognition ability and cause a high specificity towards their target. The most important data of the discussed aptasensor are given below in Table 14.

Table 14. Aptamer sequence, dissociation constant $\left(\mathrm{K}_{\mathrm{D}}\right)$, limit of detection (LOD), real sample analysis (RSA) and realized sensor type and measuring method for lincomycin, mentioned in the corresponding references (Ref). $\mathrm{AC}=$ alternating current, $\mathrm{b}=$ buffer, $\mathrm{CV}=$ cyclic voltammetry, $\mathrm{ECL}=$ electrochemiluminescent, and me = meat.

\begin{tabular}{|c|c|c|c|c|c|c|c|}
\hline $\begin{array}{l}5^{\prime} \text { Linker } \\
\text { and Spacer }\end{array}$ & Aptamer Sequence $5^{\prime} \rightarrow 3^{\prime}$ & $\begin{array}{c}3^{\prime} \text { Linker } \\
\text { and Spacer }\end{array}$ & $\begin{array}{c}\mathrm{K}_{\mathrm{D}} \\
(\mathrm{nM})\end{array}$ & $\begin{array}{l}\text { LOD } \\
(\mathrm{nM})\end{array}$ & RSA & $\begin{array}{l}\text { Sensor Type/ } \\
\text { Method }\end{array}$ & $\operatorname{Ref}^{1}$ \\
\hline$C$ dot & $\begin{array}{c}\text { CGC GTG ATG TGG TCG } \\
\text { ATG CGA TAC GGT GAG } \\
\text { TCG CGC CAC GGC TAC } \\
\text { ACA CGT CTC AGC GA }\end{array}$ & - & - & $0.00016(b)$ & me & $\begin{array}{c}\mathrm{ECL} / \mathrm{CV}, \\
\mathrm{AC}\end{array}$ & [186] \\
\hline
\end{tabular}

${ }^{1}$ When naming several references, the first always describes the realized sensor with associated LOD; aptamer sequence(s) and/or associated $K_{D}$ values are derived from the additional reference(s).

\subsection{Tetracyclines}

Tetracyclines are the most widely used antibiotics besides penicillins which are of great economic importance due to their broad-spectrum activity (acting against Gram-positive, Gram-negative bacteria, Rickettsiae, Mycoplasmas, Leptospira, and some large viruses) and their low toxicity [56,57]. In some 
countries, they are widely used as nutritive antibiotics in poultry and pig fattening, which encourages resistance development. Tetracyclines inhibit protein biosynthesis by binding to the $50 \mathrm{~S}$ subunit of the ribosomes. They are formed exclusively by Streptomyces. Their name derives from their basic structure, which consists of four linearly arranged six-rings (marked in red in Figure 8).<smiles>CN(C)C1C(O)=C(C(N)=O)C(=O)C2(O)C(O)=C3C(=O)c4c(O)cccc4C(C)(O)C3C(O)C12</smiles>

(a)<smiles>CN(C)C1C(O)=C(C(N)=O)C(=O)C2(O)C(O)=C3C(=O)c4c(O)cccc4C(C)(O)C3CC12</smiles>

(b)

Figure 8. Chemical structure of: (a) oxytetracycline and (b) tetracycline. The basic structure of the tetracyclines is marked in red.

\subsubsection{Oxytetracycline}

Oxytetracycline (Figure 8a) is the primary product in the formation of tetracyclines by Streptomyces [57].

Niazi et al. [187] selected oxytetracycline-specific ssDNA aptamers by Flu-Mag SELEX, which was later used in a variety of studies which deal with oxytetracycline detection [188-192]. In the Flu-Mag SELEX method fluorescent labels for DNA quantification and magnetic beads for target immobilization are used for aptamer selection [193]. In further investigation they selected ssDNA aptamers specific for tetracycline, oxytetracycline, and doxycycline [194].

Kwon et al. [195] truncated 76-mer ssDNA aptamers with high affinity and specificity for oxytetracycline, selected by SELEX, to a unique shortened 8-mer ssDNA, by selection of the nucleotide bases which exhibit high homogeneity in accordance with their conserved regions. By utilization of the shortened aptamer, an ultrasensitive (Table 15) colorimetric oxytetracycline detection based on unmodified AuNPs was possible. The truncated aptamer was used in other studies [196].

An aptamer-based cantilever array sensor for the detection of oxytetracycline at nanomolar concentrations was introduced by Hou et al. [197]. The sensing cantilevers were functionalized with SAMs of the specific aptamers while the reference cantilevers were modified with 6-mercapto-1-hexanol $(\mathrm{MCH})$ SAMs to eliminate the influence of environmental disturbances, such as temperature and non-specific adsorption.

Meng et al. [196] designed an ultrasensitive surface enhanced Raman scattering (SERS) aptasensor for the detection of oxytetracycline on the basis of the Raman hot spot between gold nanoparticles (AuNPs) (13 nm and $80 \mathrm{~nm}$ diameter respectively) linked by a DNA sequence. Advantages of SERS, a molecular fingerprint spectrum, are, amongst others, ultrasensitive and non-invasive probing, compatibility with aqueous solutions, minimal sample preparation, and label-free monitoring of analytes in complex matrices. Thiolated stem-loop DNA, containing the oxytetracycline specific aptamer, was immobilized onto the surface of $80 \mathrm{~nm}$ AuNPs and, subsequently, the $13 \mathrm{~nm}$ AuNPs were functionalized with the Raman reporter molecule 4-mercaptobenzoic acid. Between the $80 \mathrm{~nm}$ AuNPs and the $13 \mathrm{~nm}$ AuNPs a SERS hot spot was formed, which is a highly-localized region of intense local field enhancement. In the presence of oxytetracycline, the aptamer preferentially bound to it, leading to a partial dehybridization of the DNA. In consequence, the $13 \mathrm{~nm}$ AuNPs approach the $80 \mathrm{~nm}$ AuNPs more closely and the Raman intensity increased significantly.

Two colorimetric aptasensors for the detection of oxytetracycline based on the immobilization of specific aptamers onto AuNP surfaces were reported [190,198]. 
Based on quenching ability of rGO [34], GO sheets [199], and GO hydrogel [200], several fluorometric assays for oxytetracycline detection are reported, which are described in Table 15.

Consequently, extensive studies have been carried out to improve the performance of aptasensors for detection of oxytetracycline based on luminescence [40,93,201], and photoelectrochemical [202,203] and electrochemical sensing systems [107,173,174,188,204-206], which are summarized in Table 15. As seen, the proposed aptasensor based on ultrasensitive surface enhanced Raman scattering reached the lowest LOD for oxytetracycline detection [196], followed by Chen et al. [174] with an amperometric one (Table 15). 
Table 15. Aptamer sequence, dissociation constant $\left(\mathrm{K}_{\mathrm{D}}\right)$, limit of detection (LOD), real sample analysis (RSA), and realized sensor type and measuring method for oxytetracycline, mentioned in the corresponding references (Ref). AEC $=$ amperometric electrochemical, apt $=$ aptamer, $b=b u f f e r, C A N=$ cantilever, cDNA = complementary DNA, $\mathrm{CO}=$ colorimetric, $\mathrm{CV}=$ cyclic voltammetry, $\mathrm{d}=$ drugs, $\mathrm{DPV}=$ differential pulse voltammetry, $\mathrm{ECL}=$ electrochemiluminescent, EIS = electrochemical impedance spectrometry, ELAA $=$ enzyme-linked aptamer assay, $\mathrm{f}=$ fish, FAM $=$ fluorescein amidite, FL $=$ fluorometric, $\mathrm{h}=\mathrm{honey}, \mathrm{LSPIA}$ $=$ light scattering particle immunoagglutination assay, $\mathrm{l} \mathrm{w}=$ lake water, $\mathrm{m}=$ milk, $\mathrm{mb}=$ mouse blood, $\mathrm{ms}=$ mouse serum, $\mathrm{mu}=\mathrm{mouse}$ urine, $\mathrm{p}=$ pork, $\mathrm{PEC}=$ photoelectrochemical, $\mathrm{rw}=$ river water, SERS = surface-enhanced Raman scattering, SWV = square wave voltammetry, and tw $=$ tap water.

\begin{tabular}{|c|c|c|c|c|c|c|c|}
\hline $5^{\prime}$ Linker and Spacer & Aptamer Sequence $5^{\prime} \rightarrow 3^{\prime}$ & $\begin{array}{l}3^{\prime} \text { Linker } \\
\text { and Spacer }\end{array}$ & $\begin{array}{c}\mathrm{K}_{\mathrm{D}} \\
(\mathrm{nM})\end{array}$ & $\begin{array}{l}\text { LOD } \\
(\mathrm{nM})\end{array}$ & RSA & $\begin{array}{l}\text { Sensor Type/ } \\
\text { Method }\end{array}$ & $\operatorname{Ref}^{1}$ \\
\hline- & $\begin{array}{c}\text { I: CGT ACG GAA TTC GCT AGC CGA CGC GCG TTG GTG } \\
\text { GTG GAT GGT GTG TTA CAC GTG TTG TGG ATC CGA GCT } \\
\text { CCA CGT G } \\
\text { II: CGT ACG GAA TTC GCT AGC ACG TTG ACG CTG GTG } \\
\text { CCC GGT TGT GGT GCG AGT GTT GTG T GG ATC CGA GCT } \\
\text { CCA CGT G } \\
\text { III: CGT ACG GAA TTC GCT AGC CGA GTT GAG CCG GGC } \\
\text { GCG GTA CGG GTA CTG GTA TGT GTG G GG ATC CGA GCT } \\
\text { CCA CGT G }\end{array}$ & - & $\begin{array}{l}\text { I: } 9.61 \\
\text { II: } 12.08 \\
\text { III: } 56.84\end{array}$ & - & - & FL & {$[187,194]$} \\
\hline- & AGG TGC AC & - & 1.104 & $0.1(b)$ & - & CO/UV-VIS & [195] \\
\hline- & $\begin{array}{l}\text { GGA ATT CGC TAG CAC GTT GAC GCT GGT GCC CGG TTG } \\
\text { TGG TGC GAG TGT TGT GTG GAT CCG AGC TCC ACG TG }\end{array}$ & $\left(\mathrm{CH}_{2}\right)_{6}-\mathrm{SH}$ & & $0.2(b)$ & - & CAN & {$[187,197]$} \\
\hline- & $\begin{array}{l}\text { CGA ACG CGC GTT GGT GGT GGA TGG TGT GTT ACA CGT } \\
\text { GTT GT }\end{array}$ & - & 9.61 & $100(b)$ & - & LSPIA & {$[187,189]$} \\
\hline- & $\begin{array}{c}\text { I: CGA CGC ACA GTC GCT GGT GCG TAC CTG GTT GCC } \\
\text { GTT GTG T } \\
\text { II: GGC GCG GCA TGG TGT GGA CTC CAG GCG GTA GGG } \\
\text { ATG TCG T } \\
\text { III: GGC GAA GGA GTC ATG TAG GTG TGG TCG AGA CCG } \\
\text { CTG TGC T } \\
\text { IV: GAA AGG GAC GTT CCA AGT TCG TAT AAG CAG TCC } \\
\text { TGT GCG T } \\
\end{array}$ & - & $\begin{array}{c}\text { I: } 4.7 \\
\text { II: } 8.0 \\
\text { III: } 9.5 \\
\text { IV: } 14.0\end{array}$ & $\begin{array}{c}\text { I: } 26.7(\mathrm{~b}) \\
\left(12.3 \times 10^{-6} \mathrm{~g} / \mathrm{L}\right) \\
\text { I: } 58.6(\mathrm{~m}) \\
\left(27 \times 10^{-6} \mathrm{~g} / \mathrm{L}\right)\end{array}$ & $\mathrm{m}$ & ELAA & [192] \\
\hline biotin & $\begin{array}{l}\text { ACC GCA CCA CCG TCA TGA GTG CGA ACT TAC GCA ATC } \\
\text { ATG ACG GTG GTG CGG TGG TG }\end{array}$ & $\mathrm{SH}$ & - & $\begin{array}{c}0.000000009(\mathrm{~b}) \\
\left(0.0435 \times 10^{-12} \mathrm{~g} / \mathrm{L}\right) \\
\end{array}$ & $\mathrm{f}$ & SERS & {$[195,196]$} \\
\hline- & $\begin{array}{c}\text { CGT ACG GAA TTC GCT AGC GGG CGG GGG TGC TGG } \\
\text { GGG AAT GGA GTG CTG CGT GCT GCG GGG ATC CGA GCT } \\
\text { CCA CGT G }\end{array}$ & - & 11.13 & 25 (b) & - & CO/UV-VIS & {$[187,190]$} \\
\hline
\end{tabular}


Table 15. Cont.

\begin{tabular}{|c|c|c|c|c|c|c|c|}
\hline $5^{\prime}$ Linker and Spacer & Aptamer Sequence $5^{\prime} \rightarrow 3^{\prime}$ & $\begin{array}{l}3^{\prime} \text { Linker } \\
\text { and Spacer }\end{array}$ & $\begin{array}{c}\mathrm{K}_{\mathrm{D}} \\
(\mathrm{nM})\end{array}$ & $\begin{array}{l}\text { LOD } \\
(\mathrm{nM})\end{array}$ & RSA & $\begin{array}{l}\text { Sensor Type/ } \\
\text { Method }\end{array}$ & $\operatorname{Ref}^{1}$ \\
\hline- & $\begin{array}{c}\text { CGT ACG GAA TTC GCT AGC GGG CGG GGG TGC TGG } \\
\text { GGG AAT GGA GTG CTG CGT GCT GCG GGG ATC CGA GCT } \\
\text { CCA CGT G }\end{array}$ & - & - & $\begin{array}{c}1(\mathrm{~b}) \\
1(\mathrm{tw})\end{array}$ & $\mathrm{tw}$ & $\mathrm{CO} / \mathrm{UV}-\mathrm{VIS}$ & {$[187,198]$} \\
\hline FAM & $\begin{array}{c}\text { CGT ACG GAA TTC GCT AGC GGG CGG GGG TGC GGG AAT } \\
\text { GGA GTG CTG CGT GCT GCG GGG ATC CGA GCT CCA } \\
\text { CGT G }\end{array}$ & - & & $10(\mathrm{~b})$ & lw & FL & {$[34,187]$} \\
\hline $\begin{array}{l}\text { apt: biotin } \\
\text { cDNA: FAM }\end{array}$ & $\begin{array}{c}\text { apt: GGA ATT CGC TAG CAC GTT GAC GCT GGT GCC CGG } \\
\text { TTG TGG TGC GAG TGT TGT GTG GAT CCG AGC TCC } \\
\text { ACG TG } \\
\text { cDNA: ACA CAA CAC TCG CAC CAC AAC CGG GCA CCA } \\
\text { GCG TCA ACG T }\end{array}$ & - & - & $\begin{array}{c}1.85(\mathrm{~b}) \\
\left(0.85 \times 10^{-6} \mathrm{~g} / \mathrm{L}\right)\end{array}$ & $\mathrm{m}, \mathrm{h}, \mathrm{p}$ & FL & {$[82,187]$} \\
\hline- & $\begin{array}{c}\text { apt: CGT ACG GAA TTC GCT AGC GGG CGG GGG TGC GGG } \\
\text { AAT GGA GTG CTG CGT GCT GCG GGG ATC CGA GCT CCA } \\
\text { CGT G } \\
\text { cDNA I: AAT TCC GTA CG } \\
\text { cDNA II: CGT ACG GAA TT }\end{array}$ & cDNA I: FAM & - & $10(b)$ & $\mathrm{m}, \mathrm{tw}$ & FL & [199] \\
\hline FAM & $\begin{array}{l}\text { CGT ACG GAA TTC GCT AGC GGG CGG GGG TGC TGG } \\
\text { GGG AAT GGA GTG CTG CGT GCT GCG GGG ATC CGA GCT } \\
\text { CCA CGT G }\end{array}$ & - & - & $\begin{array}{c}54.3(\mathrm{~b}) \\
\left(25 \times 10^{-6} \mathrm{~g} / \mathrm{L}\right)\end{array}$ & $\mathrm{tw}, \mathrm{rw}$ & FL & [200] \\
\hline $\begin{array}{l}\text { apt: } \\
\mathrm{NH}_{2} \\
\text { cDNA: } \mathrm{NH}_{2}\end{array}$ & $\begin{array}{l}\text { apt: GGA ATT CGC TAG CAC GTT GAC GCT GGT GCC CGG } \\
\text { TTG TGG TGC GAG TGT TGT GTG GAT CCG AGC TCC ACG } \\
\text { TG } \\
\text { cDNA: CGG ATC CAC ACA ACA }\end{array}$ & - & - & $\begin{array}{c}0.078(\mathrm{~b}) \\
\left(0.036 \times 10^{-6} \mathrm{~g} / \mathrm{L}\right)\end{array}$ & $\mathrm{m}$ & ECL & {$[40,187]$} \\
\hline $\begin{array}{l}\text { apt: } \\
\mathrm{NH}_{2} \\
\text { cDNA: } \\
\mathrm{NH}_{2} \\
\end{array}$ & $\begin{array}{c}\text { apt: GGA ATT CGC TAG CAC GTT GAC GCT GGT GCC CGG } \\
\text { TTG TGG TGC GAG TGT TGT GTG GAT CCG AGC TCC ACG } \\
\text { TG } \\
\text { cDNA: CAA CGT GCT AGC GAA }\end{array}$ & - & - & $\begin{array}{c}0.12(\mathrm{~b}) \\
\left(0.054 \times 10^{-6} \mathrm{~g} / \mathrm{L}\right)\end{array}$ & $\mathrm{m}$ & ECL & {$[187,201]$} \\
\hline $\begin{array}{l}\text { apt: } \\
\text { biotin } \\
\text { cDNA: } \\
\text { SH-( }\left(\mathrm{CH}_{2}\right)_{6}\end{array}$ & $\begin{array}{c}\text { apt: GGA ATT CGC TAG CAC GTT GAC GCT GGT GCC CGG } \\
\text { TTG TGG TGC GAG TGT GTG GAT CCG AGC TCC ACG TG } \\
\text { cDNA: AAA ATC CAC ACA ACA }\end{array}$ & - & - & $\begin{array}{c}0.043(\mathrm{~b}) \\
\left(0.02 \times 10^{-6} \mathrm{~g} / \mathrm{L}\right)\end{array}$ & $\mathrm{m}$ & ECL & [93] \\
\hline $\mathrm{NH}_{2}-\left(\mathrm{CH}_{2}\right)_{6}$ & $\begin{array}{l}\text { GGA ATT CGC TAG CAC GTT GAC GCT GGT GCC CGG TTG } \\
\text { TGG TGC GAG TGT TGT GTG GAT CCG AGC TCC ACG TG }\end{array}$ & - & - & $0.9(b)$ & d & PEC/EIS & {$[187,202]$} \\
\hline
\end{tabular}


Table 15. Cont.

\begin{tabular}{|c|c|c|c|c|c|c|c|}
\hline $5^{\prime}$ Linker and Spacer & Aptamer Sequence $5^{\prime} \rightarrow 3^{\prime}$ & $\begin{array}{l}3^{\prime} \text { Linker } \\
\text { and Spacer }\end{array}$ & $\begin{array}{c}\mathrm{K}_{\mathrm{D}} \\
(\mathrm{nM})\end{array}$ & $\begin{array}{l}\text { LOD } \\
(\mathrm{nM})\end{array}$ & RSA & $\begin{array}{l}\text { Sensor Type/ } \\
\text { Method }\end{array}$ & $\operatorname{Ref}^{1}$ \\
\hline $\begin{array}{l}\text { cDNA I: SH } \\
\text { cDNA II: SH } \\
\text { cDNA III: SH }\end{array}$ & $\begin{array}{c}\text { apt: GGA ATT CGC TAG CAC GTT GAC GCT GGT GCC CGG } \\
\text { TTG TGG TGC GAG TGT TGT GTG GAT CCG AGC TCC ACG } \\
\text { TG } \\
\text { cDNA I: CAC GTG GAG CTC GGA TCC ACA CAA CAC TCG } \\
\text { CAC CAC AAC CGG GCA CCA GCG TCA ACG TGC TAG } \\
\text { CGA ATT CC } \\
\text { cDNA II: CAC GTG GAG CTC GGA TCC AC } \\
\text { cDNA III: CAC GTG GAG CTC GGA TCC ACA CAA CAC TCG } \\
\text { CAC CA }\end{array}$ & $\begin{array}{c}\text { cDNA I: (TTT) })_{20^{-}} \\
\text {ACG TG-NH } 2 \\
\text { cDNA II: (TTT) })_{5-}^{-} \\
\text {ACG TG-NH }{ }_{2} \\
\text { cDNA III: } \\
(\text { TTT })_{10}-\text { ACG } \\
\text { TG-NH }{ }_{2}\end{array}$ & - & $0.19(b)$ & $\mathrm{m}, \mathrm{w}, \mathrm{c}$ & PEC & [203] \\
\hline- & $\begin{array}{l}\text { GGA ATT CGC TAG CAC GTT GAC GCT GGT GCC CGG TTG } \\
\text { TGG TGC GAG TGT TGT GTG GAT CCG AGC TCC ACG TG }\end{array}$ & $\mathrm{C}_{3}-\mathrm{SH}$ & 11.13 & $1(b)$ & - & $\mathrm{AEC} / \mathrm{SWV}$ & {$[187,188]$} \\
\hline cDNA: $\mathrm{SH}-\left(\mathrm{CH}_{2}\right)_{6}$ & $\begin{array}{c}\text { apt: CGT ACG GAA TTC GCT AGC GGG CGG GGG TGC GGG } \\
\text { AAT GGA GTG CTG CGT GCT GCG GGG ATC CGA GCT CCA } \\
\text { CGT G } \\
\text { cDNA: GCA TGC CTT AAG CGA TCG CCA TAT TAT AAG } \\
\text { GCA TGC }\end{array}$ & cDNA: ferrocene & - & $\begin{array}{c}21.3(\mathrm{~b}) \\
\left(9.8 \times 10^{-6} \mathrm{~g} / \mathrm{L}\right)\end{array}$ & $\begin{array}{l}\mathrm{mb}, \mathrm{ms} \\
\mathrm{mu}\end{array}$ & $\mathrm{AEC} / \mathrm{SWV}$ & [204] \\
\hline biotin $C_{3}$ & $\begin{array}{l}\text { GGA ATT CGC TAG CAC GTT GAC GCT GGT GCC CGG TTG } \\
\text { TGG TGC GAG TGT TGT }\end{array}$ & - & - & $\begin{array}{c}0.005(\mathrm{~b}) \\
\left(2.3 \times 10^{-9} \mathrm{~g} / \mathrm{L}\right)\end{array}$ & $\mathrm{h}$ & $\mathrm{AEC} / \mathrm{CV}$ & [205] \\
\hline- & $\begin{array}{c}\text { TCA CGT TGA CGC TGG TGC CCG GTT GTG GTG GGA GTG } \\
\text { TTG TGT }\end{array}$ & $\left(\mathrm{CH}_{2}\right)_{6}-\mathrm{NH}_{2}$ & 4.7 & $0.00018(b)$ & $\mathrm{m}$ & $\mathrm{AEC} / \mathrm{SWV}$ & {$[107,187]$} \\
\hline $\begin{array}{l}\text { cDNA I: } \mathrm{SH}-\left(\mathrm{CH}_{2}\right)_{6} \\
\text { cDNA II: } \\
\mathrm{NH}_{2}-\left(\mathrm{CH}_{2}\right)_{6}\end{array}$ & $\begin{array}{c}\text { apt: ACG TTG ACG CTG GTG CCC GGT TGT GGT GGG AGT } \\
\text { GTT GTG T } \\
\text { cDNA I: CTA CCA TTT TTT CGC CGA CC } \\
\text { cDNA II: GGT CGG CGA AAA AAT GGT AG }\end{array}$ & cDNA I: $\left(\mathrm{CH}_{2}\right)_{6}-\mathrm{PHO}$ & - & $\begin{array}{c}0.22(\mathrm{~b}) \\
\left(0.1 \times 10^{-6} \mathrm{~g} / \mathrm{L}\right)\end{array}$ & $\mathrm{m}$ & AEC/SWV & [173] \\
\hline $\begin{array}{l}\text { cDNA I: } \mathrm{NH}_{2}-\left(\mathrm{CH}_{2}\right)_{6} \\
\text { cDNA II: } \mathrm{SH}-\left(\mathrm{CH}_{2}\right)_{6}\end{array}$ & $\begin{array}{c}\text { apt: ACG TTG ACG CTG GTG CCC GGT TGT GGT GCG AGT } \\
\text { GTT GTG TCC TAT GCA GTT T } \\
\text { cDNA I: TTT CGC TGT GAC } \\
\text { ACA CAA CAC TCG GT } \\
\text { cDNA II: TTT GTG CAT AGG GTC ACAG }\end{array}$ & - & - & $0.0000048(b)$ & $\mathrm{m}$ & $\mathrm{AEC} / \mathrm{SWV}$ & [174] \\
\hline $\mathrm{SH}$ & $\begin{array}{l}\text { CGA CGC ACA GTC GCT GGT GCG TAC CTG GTT GCC GTT } \\
\text { GTG T }\end{array}$ & - & - & $0.498(b)$ & $\mathrm{h}$ & $\mathrm{AEC} / \mathrm{DPV}$ & [206] \\
\hline
\end{tabular}

${ }^{1}$ When naming several references, the first always describes the realized sensor with associated LOD; aptamer sequence(s) and/or associated $\mathrm{K}_{\mathrm{D}}$ values are derived from the additional reference(s). 


\subsubsection{Tetracycline}

Tetracycline (Figure $8 \mathbf{b}$ ) is used in veterinary medicine and treatment, as well as the prevention of microbial infections, such as respiratory tract infections, arthritis, and severe acne [207]. In particular, it has been used as a feed additive to promote the growth of livestock in the agriculture sector [208].

In 2008 Niazi et al. [194] identified tetracycline group-specific ssDNA aptamers by modified SELEX (Toggle-SELEX combined with Flu-Mag SELEX) and Müller et al. [209] characterized tetracycline-specific RNA aptamers and their ligand binding properties.

Kwon et al. [195] truncated 76-mer ssDNA aptamers with high affinity and specificity for oxytetracycline to a unique shortened 8-mer ssDNA with selectivity to oxytetracycline, tetracycline, doxycycline, and chlortetracycline.

Aslipashaki et al. [207] developed an aptamer-based solid-phase extraction followed by electrospray ionization-ion mobility spectrometry (ESI-IMS) for tetracycline separation and detection in biological fluids via covalent binding of aptamers onto CNBr-activated sepharose.

Jeong and Rhee Paeng [210] introduced a competitive enzyme-linked aptamer assay (ELAA) for the determination of tetracycline residue in bovine milk using two different aptamers individually, one 76mer DNA and a 57mer RNA aptamer. The RNA aptamer featured a higher affinity to tetracycline than the DNA aptamer, and also the LODs obtained for the RNA aptamer were lower than the one for the DNA aptamer, as well as in buffer and in milk (Table 16).

Since tetracycline detection is very important in food safety, plenty of research has been devoted to the development of sensitive, selective, and specific aptasensors on the basis of different sensing methods, like colorimetric [195,211-215], surface-enhanced Raman spectroscopic [216,217], FAM-labelled and label-free [218-221] fluorometric, photoelectrochemical [208,222,223], electrochemiluminescent [93], impedimetric and amperometric electrochemical [41,224-239] methods. Among them, the proposed electrochemical aptasensors by Jahanbani's team [236] showed ultrahigh sensitivity towards tetracycline. They fabricated two similar electrochemical aptasensors based on the immobilization of aptamers on the surface of a modified carbon paste electrode with oleic acid (aptasensor I), and a magnetic bar carbon paste electrode with $\mathrm{Fe}_{3} \mathrm{O}_{4}$ magnetic nanoparticles and oleic acid (aptasensor II). The aptasensors II showed a wider dynamic range and lower LODs ( $3.8 \mathrm{fM}$ and $0.31 \mathrm{nM}$ with electrochemical impedance spectroscopy (EIS) and differential pulse voltammetry (DPV) methods, respectively) than aptasensor $\mathrm{I}$.

Summarized, around half of all developed aptamer-based biosensors for the detection of tetracycline are based on electrochemical sensor principles (either impedimetric or amperometric). Colorimetric aptasensors are frequently used, mainly due to their simple handling and evaluation. In almost all of the mentioned studies, the same tetracycline-specific ssDNA aptamer was used, which was selected and investigated by Niazi et al. [194]. The summarized data in Table 16 shows, in comparison between the RNA aptamer [210] and the ssDNA aptamers applied for tetracycline detection, that the RNA aptamer featured a lower $\mathrm{K}_{\mathrm{D}}$ and, thus, a much higher affinity to tetracycline than the DNA aptamers [210]. By shortening the ssDNA sequence to the possible minimum with sufficient affinity, Kwon et al. [195] managed to achieve a similar high affinity of the ssDNA aptamer to the target as Jeong et al. [210] reached with the RNA aptamer. 
Table 16. Aptamer sequence, dissociation constant $\left(\mathrm{K}_{\mathrm{D}}\right)$, limit of detection (LOD), real sample analysis (RSA), and realized sensor type and measuring method for tetracycline, mentioned in the corresponding references (Ref). AEC $=$ amperometric electrochemical, apt $=\mathrm{aptamer}, \mathrm{b}=\mathrm{buffer}, \mathrm{cap}=\mathrm{capture}$ probe, $\mathrm{cDNA}=$ complementary DNA, CO = colorimetric, DPV = differential pulse voltammetry, EIS = electrochemical impedance spectrometry, ELAA = enzyme-linked aptamer assay, ESI-MS = electrospray ionization-ion mobility spectrometry, FAM = fluorescein amidite, FIS = Faradaic impedance spectroscopy, FL = fluorometric, $\mathrm{h}=$ honey, $\mathrm{hp}=$ human plasma, hs = human serum, hu = human urine, IEC = impedimetric electrochemical, $\mathrm{m}=$ milk, $\mathrm{p}=$ pork, PEC = photoelectrochemical, $\mathrm{rs}=$ rat serum, $\mathrm{SERS}=$ surface enhanced Raman scattering, $\mathrm{SWV}=$ square wave voltammetry, $\mathrm{tw}=$ tap water, $\mathrm{u}=\mathrm{urine}$, and $\mathrm{uw}=\mathrm{ultrapure}$ water.

\begin{tabular}{|c|c|c|c|c|c|c|c|}
\hline $\begin{array}{l}5^{\prime} \text { Linker } \\
\text { and Spacer }\end{array}$ & Aptamer Sequence $5^{\prime} \rightarrow 3$ & $\begin{array}{l}3^{\prime} \text { Linker } \\
\text { and Spacer }\end{array}$ & $\begin{array}{c}\mathrm{K}_{\mathrm{D}} \\
(\mathrm{nM})\end{array}$ & $\begin{array}{l}\text { LOD } \\
(\mathrm{nM})\end{array}$ & RSA & $\begin{array}{l}\text { Sensor Type/ } \\
\text { Method }\end{array}$ & $\operatorname{Ref}^{1}$ \\
\hline- & $\begin{array}{l}\text { I: CGT ACG GAA TTC GCT AGC CCC CCG GCA GGC CAC GGC TTG } \\
\text { GGT TGG TCC CAC TGC GCG TGG ATC CGA GCT CCA CGT G } \\
\text { II: CGT ACG GAA TTC GCT AGC GGG GGC ACA CAT GTA GGT GCT } \\
\text { GTC CAG GTG TGG TTG TGG TGG ATC CGA GCT CCA CGT G } \\
\text { III: CGT ACG GAA TTC GCT AGC GGG CGG GGG TGC TGG GGG AAT } \\
\text { GGA GTG CTG CGT GCT GCG G GG ATC CGA GCT CCA CGT G }\end{array}$ & - & $\begin{array}{l}\text { I } 63 \\
\text { II } 70 \\
\text { III } 100\end{array}$ & - & - & - & [194] \\
\hline $\mathrm{NH}_{2}$ & $\begin{array}{l}\text { CGT ACG GAA TTC GCT AGC CCC CCG GCA GGC CAC GGC TTG } \\
\text { GGT TGG TCC CAC TGC GCG TGG ATC CGA GCT CCA CGT G }\end{array}$ & $\mathrm{C}_{6}$ & 63.6 & $\begin{array}{c}42.8(\mathrm{hu}) \\
\left(0.019 \times 10^{-3} \mathrm{~g} / \mathrm{L}\right) \\
83.3(\mathrm{p}) \\
\left(0.037 \times 10^{-3} \mathrm{~g} / \mathrm{L}\right)\end{array}$ & hu, hp & ESI-IMS & {$[207,228]$} \\
\hline II biotin & $\begin{array}{c}\text { I CGT ACG GAA TTC GCT AGC CCC CCG GCA GGC CAC GGC TTG } \\
\text { GGT TGG TCC CAC TGC GCG TGG ATC CGA GCT CCA CGT G } \\
\text { II GAG CCU AAA ACA UAC CAG AGA AAU CUG GAG AGG UGA } \\
\text { AGA AUA CGA CCA CCU AGG CUC }\end{array}$ & I biotin & $\begin{array}{l}\text { I: } 63 \\
\text { II: } 0.77\end{array}$ & $\begin{array}{l}\text { I: } 32.7(\mathrm{~b}) \\
\text { I: } 95.2(\mathrm{~m}) \\
\text { II: } 21.0(\mathrm{~b}) \\
\text { II: } 35.1(\mathrm{~m})\end{array}$ & $\mathrm{m}$ & ELAA & {$[194,209,210]$} \\
\hline- & $\begin{array}{l}\text { CGT ACG GAA TTC GCT AGC CCC CCG GCA GGC CAC GGC TTG } \\
\text { GGT TGG TCC CAC TGC GCG TGG ATC CGA GCT CCA CGT G }\end{array}$ & biotin & 63.6 & $\begin{array}{c}0.018(\mathrm{~b}) \\
\left(7.8 \times 10^{-9} \mathrm{~g} / \mathrm{L}\right) \\
0.022(\mathrm{~h}) \\
\left(9.6 \times 10^{-9} \mathrm{~g} / \mathrm{L}\right)\end{array}$ & $\mathrm{h}$ & ELAA & {$[194,240]$} \\
\hline- & $\begin{array}{l}\text { CGT ACG GAA TTC GCT AGC CCC CCG GCA GGC CAC GGC TTG } \\
\text { GGT TGG TCC CAC TGC GCG TGG ATC CGA GCT CCA CGT G }\end{array}$ & biotin & - & $\begin{array}{c}0.15(\mathrm{~b}) \\
\left(0.0659 \times 10^{-6} \mathrm{~g} / \mathrm{L}\right) \\
0.22(\mathrm{~h}) \\
\left(0.0978 \times 10^{-6} \mathrm{~g} / \mathrm{L}\right)\end{array}$ & $\mathrm{h}$ & ELAA & {$[194,241]$} \\
\hline- & $\begin{array}{l}\text { CGT ACG GAA TTC GCT AGC CCC CCG GCA GGC CAC GGC TTG } \\
\text { GGT TGG TCC CAC TGC GCG TGG ATC CGA GCT CCA CGT G }\end{array}$ & - & - & $11.6(b)$ & $\mathrm{m}$ & SERS & {$[194,216]$} \\
\hline $\begin{array}{l}\text { apt: } \mathrm{NH}_{2} \\
\text { cDNA: } \mathrm{NH}_{2}\end{array}$ & $\begin{array}{c}\text { apt: CGT ACG GAA TTC GCT AGC CCC CCG GCA GGC CAC GGC } \\
\text { TTG GGT TGG TCC CAC TGC GCG TGG ATC CGA GCT CCA CGT G } \\
\text { cDNA: CAA CGT GCT AGC GAA }\end{array}$ & apt: $\mathrm{NH}_{2}$ & - & $\begin{array}{c}0.0023(\mathrm{~b}) \\
\left(0.001 \times 10^{-6} \mathrm{~g} / \mathrm{L}\right)\end{array}$ & $\mathrm{m}$ & SERS & [217] \\
\hline- & AGG TGC AC & - & 1.067 & $0.1(\mathrm{~b})$ & - & CO/UV-VIS & [195] \\
\hline- & $\begin{array}{l}\text { CGT ACG GAA TTC GCT AGC CCC CCG GCA GGC CAC GGC TTG } \\
\text { GGT TGG TCC CAC TGC GCG TGG ATC CGA GCT CCA CGT G }\end{array}$ & - & - & $122(b)$ & $\mathrm{m}$ & $\mathrm{CO} / \mathrm{UV}-\mathrm{VIS}$ & {$[194,211]$} \\
\hline
\end{tabular}


Table 16. Cont.

\begin{tabular}{|c|c|c|c|c|c|c|c|}
\hline $\begin{array}{l}5^{\prime} \text { Linker } \\
\text { and Spacer }\end{array}$ & Aptamer Sequence $5^{\prime} \rightarrow 3$ & $\begin{array}{l}3^{\prime} \text { Linker } \\
\text { and Spacer }\end{array}$ & $\begin{array}{c}\mathrm{K}_{\mathrm{D}} \\
(\mathrm{nM})\end{array}$ & $\begin{array}{l}\text { LOD } \\
(\mathrm{nM})\end{array}$ & RSA & $\begin{array}{l}\text { Sensor Type/ } \\
\text { Method }\end{array}$ & $\operatorname{Ref}^{1}$ \\
\hline- & $\begin{array}{l}\text { CGT ACG GAA TTC GCT AGC CCC CCG GCA GGC CAC GGC TTG } \\
\text { GGT TGG TCC CAC TGC GCG TGG ATC CGA GCT CCA CGT G }\end{array}$ & - & - & $45.8(\mathrm{uw})$ & $\mathrm{m}$ & CO/UV-VIS & {$[194,212]$} \\
\hline- & $\begin{array}{l}\text { CGT ACG GAA TTC GCT AGC CCC CCG GCA GGC CAC GGC TTG } \\
\text { GGT TGG TCC CAC TGC GCG TGG ATC CGA GCT CCA CGT G }\end{array}$ & - & 63.6 & $\begin{array}{c}87.8(\mathrm{~b}) \\
\left(0.039 \times 10^{-3} \mathrm{~g} / \mathrm{L}\right)\end{array}$ & $\mathrm{m}$ & CO/UV-VIS & {$[194,242]$} \\
\hline- & СTC TCT CGG TGG TGT CTC TC & - & - & $\begin{array}{l}0.266(\mathrm{~b}) \\
0.347(\mathrm{~m}) \\
0.393(\mathrm{rs})\end{array}$ & $\mathrm{m}, \mathrm{rs}$ & CO/UV-VIS & {$[195,213]$} \\
\hline- & $\begin{array}{l}\text { CGT ACG GAA TTC GCT AGC CCC CCG GCA GGC CAC GGC TTG } \\
\text { GGT TGG TCC CAC TGC GCG TGG ATC CGA GCT CCA CGT G }\end{array}$ & - & 3.4 & - & - & CO/UV-VIS & {$[194,195,214]$} \\
\hline- & $\begin{array}{l}\text { CGT ACG GAA TTC GCT AGC CCC CCG GCA GGC CAC GGC TTG } \\
\text { GGT TGG TCC CAC TGC GCG TGG ATC CGA GCT CCA CGT G }\end{array}$ & - & - & $\begin{array}{c}0.0023(\mathrm{~b}) \\
\left(0.001 \times 10^{-6} \mathrm{~g} / \mathrm{L}\right)\end{array}$ & $\mathrm{h}$ & CO/UV-VIS & [215] \\
\hline $\begin{array}{l}\text { I: }(\mathrm{CT})_{4} \\
\text { II: }(\mathrm{CT})_{4} \mathrm{C} \\
\text { II: }(\mathrm{CT})_{5} \\
\text { CDNA: FAM }\end{array}$ & $\begin{array}{c}\text { I, II, III: GGG GGC ACA CAT GTA GGT GCT GTC CAG GTG TGG TTG } \\
\text { TGG T } \\
\text { cDNA: GAG GAG AGA GAG AGA TCC TC }\end{array}$ & $\begin{array}{l}\text { I: }(\mathrm{TC})_{3} \\
\text { II: }(\mathrm{CT})_{3} \mathrm{C} \\
\text { III: (TC) })_{4} \\
\text { cDNA: black } \\
\text { hole quencher }\end{array}$ & & $\begin{array}{l}\text { I: } 2.09(\mathrm{~b}) \\
\text { I: } 7.30(\mathrm{tw}) \\
\text { I: } 8.48(\mathrm{rs})\end{array}$ & $\mathrm{tw}, \mathrm{rs}$ & FL & [218] \\
\hline- & $\begin{array}{c}\text { apt: TCC CTT CCG GTG GTG CTT CCC T } \\
\text { G-quadruplex: ATG GGA AGG GAG GGA TGG GT }\end{array}$ & - & - & $0.97(b)$ & hs & FL & {$[195,219]$} \\
\hline- & $\begin{array}{c}\text { apt: CGT ACG GAA TTC GCT AGC CCC CCG GCA GGC CAC GGC } \\
\text { TTG GGT TGG TCC CAC TGC GCG TGG ATC CGA GCT CCA CGT G } \\
\text { cDNA: CAA CGT GCT AGC GAA }\end{array}$ & - & - & $\begin{array}{c}0.014(b) \\
\left(6.2 \times 10^{-9} \mathrm{~g} / \mathrm{L}\right)\end{array}$ & $\mathrm{m}, \mathrm{p}$ & FL & {$[194,220]$} \\
\hline- & $\begin{array}{l}\text { CGT ACG GAA TTC GCT AGC CCC CCG GCA GGC CAC GGC TTG } \\
\text { GGT TGG TCC CAC TGC GCG TGG ATC CGA GCT CCA CGT G }\end{array}$ & - & - & $\begin{array}{c}0.65(\mathrm{uw}) \\
\left(0.29 \times 10^{-6} \mathrm{~g} / \mathrm{L}\right)\end{array}$ & $\mathrm{m}$ & FL & {$[194,221]$} \\
\hline $\begin{array}{l}\text { apt: } \\
\text { biotin } \\
\text { cDNA: } \mathrm{SH}-\left(\mathrm{CH}_{2}\right)_{6}\end{array}$ & $\begin{array}{c}\text { apt: CGT ACG GAA TTC GCT AGC CCC CCG GCA GGC CAC GGC } \\
\text { TTG GGT TGG TCC CAC } \\
\text { TGC GCG TGG ATC CGA GCT CCA CGT G } \\
\text { cDNA: GGA CCA ACC CAA }\end{array}$ & - & - & $\begin{array}{c}0.045(\mathrm{~b}) \\
\left(0.02 \times 10^{-6} \mathrm{~g} / \mathrm{L}\right)\end{array}$ & $\mathrm{m}$ & ECL & [93] \\
\hline- & $\begin{array}{l}\text { CGT ACG GAA TTC GCT AGC CCC CCG GCA GGC CAC GGC TTG } \\
\text { GGT TGG TCC CAC TGC GCG TGG ATC CGA GCT CCA CGT G }\end{array}$ & - & - & $5.3(b)$ & $\operatorname{lw}$ & PEC & {$[208,242]$} \\
\hline $\mathrm{SH}-\left(\mathrm{CH}_{2}\right)_{6}$ & $\begin{array}{l}\text { CGT ACG GAA TTC GCT AGC CCC CCG GCA GGC CAC GGC TTG } \\
\text { GGT TGG TCC CAC TGC GCG TGG ATC CGA GCT CCA CGT G }\end{array}$ & - & - & $0.1(b)$ & $\mathrm{m}$ & PEC & {$[222,241]$} \\
\hline- & $\begin{array}{l}\text { CGT ACG GAA TTC GCT AGC CCC CCG GCA GGC CAC GGC TTG } \\
\text { GGT TGG TCC CAC TGC GCG TGG ATC CGA GCT CCA CGT G }\end{array}$ & & - & $4.5(b)$ & $\mathrm{w}$ & PEC & {$[223,242]$} \\
\hline - & $\begin{array}{l}\text { ACT CTT ATA CGG GAG CCA ACA CCA AAG CTT CTG CGC CAC } \\
\text { ACC ATA TGA GAG CAG GTG GTA CGG ATA AGC T }\end{array}$ & - & $52.5 \pm 3.6$ & $\begin{array}{c}22.5(\mathrm{~b}) \\
\left(1 \times 10^{-5} \mathrm{~g} / \mathrm{L}\right)\end{array}$ & $\mathrm{m}$ & IEC/EIS & [224] \\
\hline
\end{tabular}


Table 16. Cont.

\begin{tabular}{|c|c|c|c|c|c|c|c|}
\hline $\begin{array}{c}5^{\prime} \text { Linker } \\
\text { and Spacer }\end{array}$ & Aptamer Sequence $5^{\prime} \rightarrow 3$ & $\begin{array}{l}3^{\prime} \text { Linker } \\
\text { and Spacer }\end{array}$ & $\begin{array}{c}\mathrm{K}_{\mathrm{D}} \\
(\mathrm{nM})\end{array}$ & $\begin{array}{l}\text { LOD } \\
(\mathrm{nM})\end{array}$ & RSA & $\begin{array}{l}\text { Sensor Type/ } \\
\text { Method }\end{array}$ & $\operatorname{Ref}^{1}$ \\
\hline $\mathrm{SH}-\left(\mathrm{CH}_{2}\right)_{6}$ & $\begin{array}{l}\text { GTC TCT GTG TGC GCC AGA GAA CAC TGG GGC AGA TAT GGG } \\
\text { CCA GCA CAG AAT GAG GCC C }\end{array}$ & - & - & $\begin{array}{c}6.75(\mathrm{~b}) \\
\left(3.0 \times 10^{-6} \mathrm{~g} / \mathrm{L}\right)\end{array}$ & $\mathrm{m}$ & IEC/EIS & {$[147,225]$} \\
\hline $\mathrm{SH}-\left(\mathrm{CH}_{2}\right)_{6}$ & $\begin{array}{l}\text { GTC TCT GTG TGC GCC AGA GAA CAC TGG GGC AGA TAT GGG } \\
\text { CCA GCA CAG AAT GAG GCC C }\end{array}$ & - & - & $1.0(b)$ & $\mathrm{m}$ & IEC/EIS & {$[147,226]$} \\
\hline $\mathrm{NH}_{2}-\mathrm{CH}_{2}$ & $\begin{array}{l}\text { CGT ACG GAA TTC GCT AGC CCC CCG GCA GGC CAC GGC TTG } \\
\text { GGT TGG TCC CAC TGC GCG TGG ATC CGA GCT CCA CGT G }\end{array}$ & - & - & $1.0(b)$ & $\mathrm{m}$ & IEC/EIS & [227] \\
\hline biotin- $\mathrm{T}_{5}$ & $\begin{array}{l}\text { TTT TTG GTA CGG AAT TCG CTA GCC CCC CHG CAG GCC ACG GCT } \\
\text { TGG GTT GGT CCC ACT GCG CGT GGA TCC GAG CTC CAC GTG }\end{array}$ & - & 63.6 & $10(b)$ & - & $\mathrm{AEC} / \mathrm{SWV}$ & {$[194,228]$} \\
\hline- & - & - & - & $\begin{array}{c}2.25(\mathrm{~b}) \\
\left(1.0 \times 10^{-6} \mathrm{~g} / \mathrm{L}\right)\end{array}$ & $\mathrm{m}$ & $\mathrm{AEC} / \mathrm{CV}$ & [229] \\
\hline $\mathrm{NH}_{2}-\mathrm{CH}_{2}$ & $\begin{array}{l}\text { CGT ACG GAA TTC GCT AGC CCC CCG GCA GGC CAC GGC TTG } \\
\text { GGT TGG TCC CAC TGC GCG TGG ATC CGA GCT CCA CGT G }\end{array}$ & - & - & $5.0(b)$ & $\mathrm{m}$ & $\mathrm{AEC} / \mathrm{DPV}$ & {$[194,230]$} \\
\hline $\mathrm{NH}_{2}-\left(\mathrm{CH}_{2}\right)_{6}$ & - & - & 51800 & $\begin{array}{c}2.25(\mathrm{~b}) \\
\left(1.0 \times 10^{-6} \mathrm{~g} / \mathrm{L}\right)\end{array}$ & $\mathrm{m}$ & $\mathrm{AEC} / \mathrm{DPV}$ & [231] \\
\hline $\mathrm{NH}_{2}-\mathrm{CH}_{2}$ & $\begin{array}{l}\text { CGT ACG GAA TTC GCT AGC CCC CCG GCA GGC CAC GGC TTG } \\
\text { GGT TGG TCC CAC TGC GCG TGG ATC CGA GCT CCA CGT G }\end{array}$ & - & - & $0.32(b)$ & $\mathrm{m}$ & $\mathrm{AEC} / \mathrm{DPV}$ & {$[194,232]$} \\
\hline $\mathrm{NH}_{2}-\mathrm{CH}_{2}$ & $\begin{array}{l}\text { CGT ACG GAA TTC GCT AGC CCC CCG GCA GGC CAC GGC TTG } \\
\text { GGT TGG TCC CAC TGC GCG TGG ATC CGA GCT CCA CGT G }\end{array}$ & - & - & $0.0042(b)$ & $\mathrm{m}$ & $\begin{array}{l}\mathrm{AEC} / \mathrm{CV} \\
\mathrm{IEC} / \mathrm{EIS}\end{array}$ & {$[194,233]$} \\
\hline $\mathrm{NH}_{2}$ & $\begin{array}{l}\text { CGT ACG GAA TTC GCT AGC CCC CCG GCA GGC CAC GGC TTG } \\
\text { GGT TGG TCC CAC TGC GCG TGG ATC CGA GCT CCA CGT G }\end{array}$ & - & - & $0.000029(b)$ & d & $\mathrm{AEC} / \mathrm{DPV}$ & [234] \\
\hline $\mathrm{SH}-\left(\mathrm{CH}_{2}\right)_{6}$ & $\begin{array}{l}\text { GTC TCT GTG TGC GCC AGA GAA CAC TGG GGC AGA TAT GGG } \\
\text { CCA GCA CAG AAT GAG GCC C }\end{array}$ & - & & $10(b)$ & $\mathrm{m}$ & $\mathrm{AEC} / \mathrm{CV}$ & {$[147,235]$} \\
\hline $\mathrm{NH}_{2}$ & $\begin{array}{l}\text { CGT ACG GAA TTC GCT AGC CCC CCG GCA GGC CAC GGC TTG } \\
\text { GGT TGG TCC CAC TGC GCG TGG ATC CGA GCT CCA CGT G }\end{array}$ & - & & $\begin{array}{c}\text { aptasensor I: } \\
0.0003 \text { (b, EIS) } \\
0.029 \text { (b, DPV) } \\
\text { aptasensor II: } \\
0.0000038 \text { (b, EIS) } \\
0.00031 \text { (b, DPV) } \\
\end{array}$ & $\mathrm{m}, \mathrm{d}, \mathrm{h}, \mathrm{bs}$ & $\begin{array}{l}\text { AEC/DPV } \\
\text { IEC/EIS }\end{array}$ & [236] \\
\hline $\begin{array}{l}\text { cDNA I: SH } \\
\text { cDNA II: SH }\end{array}$ & $\begin{array}{c}\text { apt: CGT ACG GAA TTC GCT AGC CCC CCG GCA GGC CAC GGC } \\
\text { TTG GGT TGG TCC CAC TGC GCG TGG ATC CGA GCT CCA CGT G } \\
\text { cDNA I: CCA TCA GAC CTA CCA AAC ACG TGG AGC T } \\
\text { cDNA II: AGA CCT ACC AAA CGA ACC CA } \\
\text { cDNA III: AAT TCC GTA CGA AAC CAT CCA GAC TAC C }\end{array}$ & cDNA III: SH & 63 & $\begin{array}{c}0.45(\mathrm{~b}) \\
0.74(\mathrm{~m}) \\
0.71(\mathrm{~s})\end{array}$ & $\mathrm{m}, \mathrm{hs}$ & $\mathrm{AEC} / \mathrm{DPV}$ & {$[194,237]$} \\
\hline
\end{tabular}


Table 16. Cont.

\begin{tabular}{|c|c|c|c|c|c|c|c|}
\hline $\begin{array}{l}5^{\prime} \text { Linker } \\
\text { and Spacer }\end{array}$ & Aptamer Sequence $5^{\prime} \rightarrow 3$ & $\begin{array}{l}3^{\prime} \text { Linker } \\
\text { and Spacer }\end{array}$ & $\begin{array}{c}\mathrm{K}_{\mathrm{D}} \\
(\mathrm{nM})\end{array}$ & $\begin{array}{l}\text { LOD } \\
(\mathrm{nM})\end{array}$ & RSA & $\begin{array}{l}\text { Sensor Type/ } \\
\text { Method }\end{array}$ & $\operatorname{Ref}^{1}$ \\
\hline cap: $\mathrm{SH}-\left(\mathrm{CH}_{2}\right)_{6}$ & $\begin{array}{c}\text { apt: CGT ACG GAA TTC GCT AGC CCC CCG GCA GGC CAC GGC } \\
\text { TTG GGT TGG TCC CAC TGC GCG TGG ATC CGA GCT CCA CGT G } \\
\text { cap: ATG TAG CTA GGT G } \\
\text { cDNA I: CGT GTA GCA CAG CAT CAC CAC CTA GC } \\
\text { cDNA II: GCT ACA CGC GTT T }\end{array}$ & cS II: biotin & - & $20(b)$ & $\mathrm{m}$ & AEC/SWV & [41] \\
\hline- & $\begin{array}{l}\text { CGT ACG GAA TTC GCT AGC CCC CCG GCA GGC CAC GGC TTG } \\
\text { GGT TGG TCC CAC TGC GCG TGG ATC CGA GCT CCA CGT G }\end{array}$ & - & - & $0.6(b)$ & - & $\mathrm{AEC} / \mathrm{DPV}$ & [238] \\
\hline $\mathrm{SH}-\left(\mathrm{CH}_{2}\right)_{6}$ & $\begin{array}{l}\text { CGT ACG GAA TTC GCT AGC CCC CCG GCA GGC CAC GGC TTG } \\
\text { GGT TGG TCC CAC TGC GCG TGG ATC CGA GCT CCA CGT G }\end{array}$ & - & - & $\begin{array}{c}0.74(\mathrm{~b}) \\
\left(0.33 \times 10^{-6} \mathrm{~g} / \mathrm{L}\right)\end{array}$ & $\mathrm{m}$ & $\mathrm{AEC} / \mathrm{DPV}$ & {$[147,239]$} \\
\hline
\end{tabular}

${ }^{1}$ When naming several references, the first always describes the realized sensor with associated LOD; aptamer sequence(s) and/or associated $\mathrm{K}_{\mathrm{D}}$ values are derived from the additional reference(s). 


\subsection{Sulfonamides}

Sulfonamides were the first synthetic antibiotics [145]. As the name suggests they are characterized by their sulfonamide group (marked in red in Figure 9). As analogues of $p$-aminobenzoic acid they interfere with the synthesis of folic acid [5]. Sulfonamides act against enterobacteria, like Escherichia coli or Salmonella, and are mainly used to treat urinary tract infections and pneumonia.<smiles>COc1cc(NS(=O)(=O)c2ccc(N)cc2)nc(OC)n1</smiles>

Figure 9. Chemical structure of sulfadimethoxine. The sulfonamide group is marked in red.

\section{Sulfadimethoxine}

Sulfadimethoxine (Figure 9) is a cheap broad-spectrum antibiotic that is effective against bacterial and coccidial infections and used for treatment (and prevention) of poultry diseases [243,244].

Song et al. [243] selected aptamers specific for sulfadimethoxine by magnetic bead-based SELEX and identified the one with the highest affinity towards its target. The developed aptamer was utilized in various further work [244-249]. According to the data of Table 17, most of the developed aptasensors for sulfadimethoxine detection are colorimetric [75,244-247]. However, there are some reports on the aptasensors based on fluorometric [248] and photoelectrochemical sensing assays [249]. As seen, the proposed photoelectrochemical aptasensing platform based on graphene-doped $\mathrm{Bi}_{2} \mathrm{~S}_{3}$ nanorods, as photoactive materials, compared to other aptamer biosensing assays shows the higher sensitivity towards sulfadimethoxine with a detection limit of $0.55 \mathrm{nM}$ [249]. 
Table 17. Aptamer sequence, dissociation constant $\left(\mathrm{K}_{\mathrm{D}}\right)$, limit of detection (LOD), real sample analysis (RSA), and realized sensor type and measuring method for sulfadimethoxine, mentioned in the corresponding references (Ref). apt $=$ aptamer, $b=$ buffer, $c D N A=$ complementary $D N A, C O=$ colorimetric, $d=d r u g s, f=$ fish, $\mathrm{FAM}=$ fluorescein amidite, $\mathrm{FL}=$ fluorometric, $\mathrm{lw}=$ lake water, $\mathrm{m}=$ milk, and $\mathrm{PEC}=$ photoelectrochemical.

\begin{tabular}{|c|c|c|c|c|c|c|c|}
\hline $\begin{array}{l}5^{\prime} \text { Linker } \\
\text { and Spacer }\end{array}$ & Aptamer Sequence $5^{\prime} \rightarrow 3^{\prime}$ & $\begin{array}{l}3^{\prime} \text { Linker and } \\
\text { Spacer }\end{array}$ & $\begin{array}{c}\mathrm{K}_{\mathrm{D}} \\
(\mathrm{nM})\end{array}$ & $\begin{array}{l}\text { LOD } \\
(\mathrm{nM})\end{array}$ & RSA & $\begin{array}{c}\text { Sensor } \\
\text { Type/Method }\end{array}$ & $\operatorname{Ref}^{1}$ \\
\hline- & $\begin{array}{l}\text { I: GTT AGA TGG GAG GTC ATA TAG C } \\
\text { II: GAG GGC AAC GAG TGT TTA TAG A }\end{array}$ & - & $\begin{array}{l}\text { I: } 150 \\
\text { II: } 84\end{array}$ & $\begin{array}{c}\text { II: } 32.2(\mathrm{~b}) \\
\text { II: } 32.2(\mathrm{~m}) \\
\left(10 \times 10^{-6} \mathrm{~g} / \mathrm{L}\right)\end{array}$ & $\mathrm{m}$ & FL & [243] \\
\hline- & GAG GGC AAC GAG TGT TTA TAG A & FAM & - & - & - & FL, CO/UV-VIS & {$[243,246]$} \\
\hline- & GAG GGC AAC GAG TGT TTA TAG A & - & - & $\begin{array}{c}161.1(\mathrm{~b}) \\
\left(50 \times 10^{-6} \mathrm{~g} / \mathrm{L}\right)\end{array}$ & - & CO/UV-VIS & {$[243,244]$} \\
\hline- & GAG GGC AAC GAG TGT TTA TAG A & - & 84 & - & - & CO/UV-VIS & {$[75,243]$} \\
\hline- & GAG GGC AAC GAG TGT TTA TAG A & - & - & $\begin{array}{c}32.2(\mathrm{~b}) \\
\left(10 \times 10^{-6} \mathrm{~g} / \mathrm{L}\right)\end{array}$ & $\mathrm{m}$ & CO/UV-VIS & [246] \\
\hline- & GAG GGC AAC GAG TGT TTA TAG A & - & - & $22.56(b)$ & $\mathrm{lw}$ & $\mathrm{CO}$ & [247] \\
\hline- & $\begin{array}{c}\text { apt: GAG GGC AAC GAG TGT TTA TAG A } \\
\text { cDNA: CGT TGC CCT C }\end{array}$ & $\begin{array}{l}\text { apt: biotin } \\
\text { cDNA: biotin }\end{array}$ & - & $\begin{array}{c}0.35(\mathrm{~b}) \\
\left(0.11 \times 10^{-6} \mathrm{~g} / \mathrm{L}\right)\end{array}$ & $\mathrm{f}$ & FL & {$[243,248]$} \\
\hline $\mathrm{NH}_{2}$ & GAG GGC AAC GAG TGT TTA TAG A & FAM & - & $0.55(\mathrm{~b})$ & $\mathrm{m}, \mathrm{d}$ & PEC & [249] \\
\hline
\end{tabular}

${ }^{1}$ When naming several references, the first always describes the realized sensor with associated LOD; aptamer sequence(s) and/or associated $\mathrm{K}_{\mathrm{D}}$ values are derived from the additional reference(s). 


\section{Summary}

In recent years widespread and uncontrolled usage of antibiotics and, accordingly, their resistance has emerged as a serious problem. Therefore, simple, sensitive, robust, and rapid methods for evaluation of antibiotics and their residues are needed for an on-site screening analysis. The most used conventional methods for antibiotic detection are instrumental ones, such as capillary electrophoresis (CE), gas chromatography (GC), and liquid chromatography (LC), or coupled with mass spectrometry (LC-MS). Despite their wide range of applications, these methods usually have limitations, such as expensive laboratory instruments, require skilled technicians, and require time consuming separation/sample preparation methodologies. Biosensors are considered as ideal alternatives to detect antibiotics in view of their superiority, such as rapid detection, high selectivity, and in situ applications. Therefore, the development of various biosensors and the design of several new signal transduction schemes is a rapidly growing field in biological, clinical, and environmental sciences.

Among different biosensors, the aptamer-based biosensors (aptasensors) are promising tools. Electrochemical aptamer biosensors compared to other developed aptasensors are the most common ones used for antibiotic detection, because of their operational simplicity, high sensitivity, portability, and low cost. Since antibiotics are most often not electrochemically active by themselves, redox tags like methylene blue, ferrocene, or the commonly used $\mathrm{Fe}^{2+} / \mathrm{Fe}^{3+}$ system must be added. Target-induced strand displacement is one of the most widely used signal transduction strategies in aptamer-based biosensors for antibiotic detection. The challenge in replacement reactions is that the affinity of the aptamer towards the target must be stronger than to the complementary DNA (cDNA). The described indirect measuring methods, in which the target is immobilized, are usable for the proof of the function of the developed measurement method, but irrelevant for practical application.

Often a once-established aptamer sequence, specific for a target, is used for almost all further studies. In general, the $5^{\prime}$-end of the aptamer sequence is preferred for immobilization and the $3^{\prime}$-end for labeling (e.g., with FAM) of the aptamer. To evaluate the specificity of the used aptamer towards its target, structurally similar derivates and possible interfering substances are introduced into the sensing system and their influence onto the signal and the detection of the actual target are investigated. In most of the developed aptasensors DNA aptamers were used, and just a few of the mentioned papers dealt with RNA-aptamers. RNA aptamers featured lower $\mathrm{K}_{\mathrm{D}}$ values and, thus, a higher affinity to their target than DNA aptamers, but RNA is attacked and degraded faster. As shown in the tables, and also compared with the standard HPLC or ELISA methods, sensitivity and selectivity of many aptasensors are acceptable.

The most commonly investigated antibiotics detected by an aptasensor are kanamycin, chloramphenicol, tetracycline, and oxytetracycline. Therefore, a great potential for developing aptamers for other antibiotics with high affinity and specificity exists. Finally, regarding the advantages of aptamers over antibodies, aptamer-based sensors have the potential for clinical/commercial applications and point-of-care detection.

Author Contributions: Y.J. and A.M. contributed to the design and implementation of the research. A.M. wrote the manuscript and P.R. worked on the manuscript. All authors provided critical feedback and helped shape the research and manuscript.

Funding: This work was funded by the European Social Fund (ESF) in Germany.

Conflicts of Interest: The authors declare no conflict of interest. 


\section{Abbreviations}

\begin{tabular}{|c|c|}
\hline $\mathrm{AC}$ & alternating current \\
\hline AEC & amperometric electrochemical \\
\hline AuNPs & gold nanoparticles \\
\hline bsa & bovine serum albumin \\
\hline CA & chronoamperometry \\
\hline CAN & cantilever \\
\hline cDNA & complementary DNA \\
\hline CNT & carbon nanotube \\
\hline $\mathrm{CO}$ & colorimetric \\
\hline CRET & chemiluminescence resonance energy transfer \\
\hline CSRP & circular strand-replacement DNA polymerization \\
\hline $\mathrm{CV}$ & cyclic voltammetry \\
\hline Су3/Сy5 & cyanine 3 , cyanine 5 \\
\hline dsDNA & double stranded DNA \\
\hline DPV & differential pulse voltammetry \\
\hline EBFC & enzyme biofuel cell \\
\hline ECL & electrochemiluminescent \\
\hline EIS & electrochemical impedance spectroscopy \\
\hline ELAA & enzyme-linked aptamer assay \\
\hline ELISA & enzyme-linked immunosorbent assay \\
\hline ESI-IMS & electrospray ionization-ion mobility spectrometry \\
\hline FAM & fluorescein amidite \\
\hline FIS & faradaic impedance spectroscopy \\
\hline FL & fluorometric \\
\hline FRET & fluorescence resonance energy transfer \\
\hline GO & graphene oxide \\
\hline HRP & horseradish peroxidase \\
\hline IEC & impedimetric electrochemical \\
\hline$K_{\mathrm{D}}$ & dissociation constant \\
\hline LOD & limit of detection \\
\hline LCA & liquid crystal assay \\
\hline LSPIA & light scattering particle immunoagglutination assay \\
\hline LSV & linear sweep voltammetry \\
\hline MB & methylene blue \\
\hline $\mathrm{MCH}$ & 6-mercapto-1-hexanol \\
\hline MIP & molecularly imprinted polymer \\
\hline MOF & metal organic framework \\
\hline MWCNTs & multi-walled carbon nanotubes \\
\hline NPs & nanoparticles \\
\hline $\mathrm{OCV}$ & open circuit voltage \\
\hline PEC & photoelectrochemical \\
\hline QCM & quartz crystal microbalance \\
\hline QD & quantum dot \\
\hline$\widehat{\mathrm{rGO}}$ & reduced graphene oxide \\
\hline ROX & carboxy-x-rhodamine \\
\hline SAM & self-assembled monolayer \\
\hline SAW & surface acoustic wave \\
\hline SELEX & systematic evolution of ligands by exponential enrichment \\
\hline SERS & surface-enhanced Raman scattering \\
\hline SPCE & screen-printed carbon electrode \\
\hline SPE & screen-printed electrode \\
\hline SPR & surface plasmon resonance spectroscopy \\
\hline SSB & ssDNA binding protein \\
\hline ssDNA & single stranded DNA \\
\hline SWV & square wave voltammetry \\
\hline UCNPs & upconversion nanoparticles \\
\hline
\end{tabular}




\section{References}

1. Ventola, C.L. The antibiotic resistance crisis: Part 1: Causes and threats. Pharm. Ther. A Peer Rev. J. Formul. Manag. 2015, 40, 277-283.

2. Centers for Disease Control and Prevention, Office of Infectious. Antibiotic Resistance Threats in the United States. Available online: http:/ / www.cdc.gov/drugresistance/ (accessed on 17 May 2018).

3. Read, A.F.; Woods, R.J. Antibiotic resistance management. Evol. Med. Public Health 2014, 2014, 147. [CrossRef] [PubMed]

4. Ventola, C.L. The antibiotic resistance crisis: Part 2: Management strategies and new agents. Pharm. Ther. A Peer Rev. J. Formul. Manag. 2015, 40, 344-352.

5. Gualerzi, C.O.; Brandi, L.; Fabbretti, A.; Pon, C.L. (Eds.) Antibiotics: Targets, Mechanisms and Resistance; Wiley-VCH Verlag: Weinheim, Germany, 2014.

6. Briscoe, S.E.; McWhinney, B.C.; Lipman, J.; Roberts, J.A.; Ungerer, J.P.J. A method for determining the free (unbound) concentration of ten beta-lactam antibiotics in human plasma using high performance liquid chromatography with ultraviolet detection. J. Chromatogr. B 2012, 907, 178-184. [CrossRef] [PubMed]

7. Dai, X.-H.; Xue, Y.-G.; Liu, H.-J.; Dai, L.-L.; Yan, H.; Li, N. Development of Determination Method of Fluoroquinolone Antibiotics in Sludge Based on Solid Phase Extraction and HPLC-Fluorescence Detection Analysis. Huan Jing Ke Xue 2016, 37, 1553-1561. [PubMed]

8. Van den Meersche, T.; van Pamel, E.; van Poucke, C.; Herman, L.; Heyndrickx, M.; Rasschaert, G.; Daeseleire, E. Development, validation and application of an ultra high performance liquid chromatographic-tandem mass spectrometric method for the simultaneous detection and quantification of five different classes of veterinary antibiotics in swine manure. J. Chromatogr. A 2016, 1429, 248-257. [CrossRef] [PubMed]

9. Yu, Y.-J.; Wu, H.-L.; Fu, H.-Y.; Zhao, J.; Li, Y.-N.; Li, S.-F.; Kang, C.; Yu, R.-Q. Chromatographic background drift correction coupled with parallel factor analysis to resolve coelution problems in three-dimensional chromatographic data: Quantification of eleven antibiotics in tap water samples by high-performance liquid chromatography coupled with a diode array detector. J. Chromatogr. A 2013, 1302, 72-80. [CrossRef] [PubMed]

10. Yang, S.; Zhu, X.; Wang, J.; Jin, X.; Liu, Y.; Qian, F.; Zhang, S.; Chen, J. Combustion of hazardous biological waste derived from the fermentation of antibiotics using TG-FTIR and Py-GC/MS techniques. Bioresour. Technol. 2015, 193, 156-163. [CrossRef] [PubMed]

11. Berendsen, B.J.A.; Wegh, R.S.; Memelink, J.; Zuidema, T.; Stolker, L.A.M. The analysis of animal faeces as a tool to monitor antibiotic usage. Talanta 2015, 132, 258-268. [CrossRef] [PubMed]

12. Martinez-Carballo, E.; Gonzalez-Barreiro, C.; Scharf, S.; Gans, O. Environmental monitoring study of selected veterinary antibiotics in animal manure and soils in Austria. Environ. Pollut. 2007, 148, 570-579. [CrossRef] [PubMed]

13. Haller, M.Y.; Müller, S.R.; McArdell, C.S.; Alder, A.C.; Suter, M.J.-F. Quantification of veterinary antibiotics (sulfonamides and trimethoprim) in animal manure by liquid chromatography-mass spectrometry. J. Chromatogr. A 2002, 952, 111-120. [CrossRef]

14. Gbylik-Sikorska, M.; Posyniak, A.; Sniegocki, T.; Zmudzki, J. Liquid chromatography-tandem mass spectrometry multiclass method for the determination of antibiotics residues in water samples from water supply systems in food-producing animal farms. Chemosphere 2015, 119, 8-15. [CrossRef] [PubMed]

15. Koyun, A.; Ahlatcolu, E.; Koca, Y. Biosensors and Their Principles. In Medical Technology Management and Patient Safety; Sezdi, M., Ed.; InTech Open Access Publisher: London, UK, 2012.

16. Mungroo, N.A.; Neethirajan, S. Biosensors for the detection of antibiotics in poultry industry-A review. Biosensors 2014, 4, 472-493. [CrossRef] [PubMed]

17. Ellington, A.D.; Szostak, J.W. In vitro selection of RNA molecules that bind specific ligands. Nature 1990, 346, 818-822. [CrossRef] [PubMed]

18. Stoltenburg, R.; Reinemann, C.; Strehlitz, B. SELEX-A (r)evolutionary method to generate high-affinity nucleic acid ligands. Biomol. Eng. 2007, 24, 381-403. [CrossRef] [PubMed]

19. Wang, R.E.; Wu, H.; Niu, Y.; Cai, J. Improving the stability of aptamers by chemical modification. Curr. Med. Chem. 2011, 18, 4126-4138. [CrossRef] [PubMed] 
20. Jayasena, S.D. Aptamers: An emerging class of molecules that rival antibodies in diagnostics. Clin. Chem. 1999, 45, 1628-1650. [PubMed]

21. Tuerk, C.; Gold, L. Systematic evolution of ligands by exponential enrichment: RNA ligands to bacteriophage T4 DNA polymerase. Science 1990, 249, 505-510. [CrossRef] [PubMed]

22. Song, K.-M.; Lee, S.; Ban, C. Aptamers and their biological applications. Sensors 2012, 12, 612-631. [CrossRef] [PubMed]

23. Drolet, D.W.; Moon-McDermott, L.; Romig, T.S. An enzyme-linked oligonucleotide assay. Nat. Biotechnol. 1996, 14, 1021-1025. [CrossRef] [PubMed]

24. Davis, K.A.; Abrams, B.; Lin, Y.; Jayasena, S.D. Use of a high affinity DNA ligand in flow cytometry. Nucleic Acids Res. 1996, 24, 702-706. [CrossRef] [PubMed]

25. Song, S.; Wang, L.; Li, J.; Fan, C.; Zhao, J. Aptamer-based biosensors. Trends Anal. Chem. 2008, $27,108-117$. [CrossRef]

26. Gründler, P. Chemical sensors: An introduction for scientists and engineers; Springer: Berlin/Heidelberg, Germany, 2007.

27. Pfeiffer, F.; Mayer, G. Selection and Biosensor Application of Aptamers for Small Molecules. Front. Chem. 2016, 4, 25. [CrossRef] [PubMed]

28. Hall, E.A.; Hummel, G. Biosensoren; Mit 24 Tabellen; Springer: Berlin, Germany, 1995.

29. Anderson, M.L.; Morris, C.A.; Stroud, R.M.; Merzbacher, C.I.; Rolison, D.R. Colloidal Gold Aerogels: Preparation, Properties, and Characterization. Langmuir 1999, 15, 674-681. [CrossRef]

30. Mayer, K.M.; Hafner, J.H. Localized surface plasmon resonance sensors. Chem. Rev. 2011, 111, 3828-3857. [CrossRef] [PubMed]

31. Liu, S.; Leech, D.; Ju, H. Application of Colloidal Gold in Protein Immobilization, Electron Transfer, and Biosensing. Anal. Lett. 2003, 36, 1-19. [CrossRef]

32. Sharma, T.K.; Ramanathan, R.; Weerathunge, P.; Mohammadtaheri, M.; Daima, H.K.; Shukla, R.; Bansal, V. Aptamer-mediated 'turn-off/turn-on' nanozyme activity of gold nanoparticles for kanamycin detection. Chem. Commun. 2014, 50, 15856-15859. [CrossRef] [PubMed]

33. Wang, E.R.; Zhang, Y.; Cai, J.; Cai, W.; Gao, T. Aptamer-Based Fluorescent Biosensors. Curr. Med. Chem. 2011, 18, 4175-4184. [CrossRef] [PubMed]

34. Zhao, H.; Gao, S.; Liu, M.; Chang, Y.; Fan, X.; Quan, X. Fluorescent assay for oxytetracycline based on a long-chain aptamer assembled onto reduced graphene oxide. Microchim. Acta 2013, 180, 829-835. [CrossRef]

35. Swathi, R.S.; Sebastian, K.L. Resonance energy transfer from a dye molecule to graphene. J. Chem. Phys. 2008, 129, 54703. [CrossRef] [PubMed]

36. Swathi, R.S.; Sebastian, K.L. Long range resonance energy transfer from a dye molecule to graphene has (distance) $)^{-4}$ dependence. J. Chem. Phys. 2009, 130, 86101. [CrossRef] [PubMed]

37. Förster, T. Zwischenmolekulare Energiewanderung und Fluoreszenz. Ann. Phys. 1948, 437, 55-75. [CrossRef]

38. Zhou, B.; Shi, B.; Jin, D.; Liu, X. Controlling upconversion nanocrystals for emerging applications. Nat. Nanotechnol. 2015, 10, 924-936. [CrossRef] [PubMed]

39. Wang, F.; Liu, X. Recent advances in the chemistry of lanthanide-doped upconversion nanocrystals. Chem. Soc. Rev. 2009, 38, 976-989. [CrossRef] [PubMed]

40. Fang, C.; Wu, S.; Duan, N.; Dai, S.; Wang, Z. Highly sensitive aptasensor for oxytetracycline based on upconversion and magnetic nanoparticles. Anal. Methods 2015, 7, 2585-2593. [CrossRef]

41. Xue, J.; Liu, J.; Wang, C.; Tian, Y.; Zhou, N. Simultaneous electrochemical detection of multiple antibiotic residues in milk based on aptamers and quantum dots. Anal. Methods 2016, 8, 1981-1988. [CrossRef]

42. Miao, Y.; Gan, N.; Li, T.; Cao, Y.; Hu, F.; Chen, Y. An ultrasensitive fluorescence aptasensor for chloramphenicol based on FRET between quantum dots as donor and the magnetic $\mathrm{SiO}_{2} @ \mathrm{Au} \mathrm{NPs}$ probe as acceptor with exonuclease-assisted target recycling. Sens. Actuators B Chem. 2016, 222, 1066-1072. [CrossRef]

43. Miao, Y.-B.; Ren, H.-X.; Gan, N.; Zhou, Y.; Cao, Y.; Li, T.; Chen, Y. A homogeneous and "off-on" fluorescence aptamer-based assay for chloramphenicol using vesicle quantum dot-gold colloid composite probes. Anal. Chim. Acta 2016, 929, 49-55. [CrossRef] [PubMed]

44. Namdari, P.; Negahdari, B.; Eatemadi, A. Synthesis, properties and biomedical applications of carbon-based quantum dots: An updated review. Biomed. Pharmacother. 2017, 87, 209-222. [CrossRef] [PubMed]

45. Walling, M.A.; Novak, J.A.; Shepard, J.R.E. Quantum dots for live cell and in vivo imaging. Int. J. Mol. Sci. 2009, 10, 441-491. [CrossRef] [PubMed] 
46. Feng, C.; Dai, S.; Wang, L. Optical aptasensors for quantitative detection of small biomolecules: A review. Biosens. Bioelectron. 2014, 59, 64-74. [CrossRef] [PubMed]

47. Nguyen, H.H.; Park, J.; Kang, S.; Kim, M. Surface plasmon resonance: A versatile technique for biosensor applications. Sensors 2015, 15, 10481-10510. [CrossRef] [PubMed]

48. Schlücker, S. Surface-enhanced Raman spectroscopy: Concepts and chemical applications. Angew. Chem. Int. Ed. 2014, 53, 4756-4795. [CrossRef] [PubMed]

49. Chen, M.; Gan, N.; Zhou, Y.; Li, T.; Xu, Q.; Cao, Y.; Chen, Y. A novel aptamer- metal ions- nanoscale MOF based electrochemical biocodes for multiple antibiotics detection and signal amplification. Sens. Actuators B Chem. 2017, 242, 1201-1209. [CrossRef]

50. Hayat, A.; Marty, J.L. Aptamer based electrochemical sensors for emerging environmental pollutants. Front. Chem. 2014, 2, 41. [CrossRef] [PubMed]

51. Nelson, D.L.; Cox, M.M.; Lehninger, A.L. Lehninger Biochemie; Mit 131 Tabellen, 4, Vollst. überarb. u. erw. Aufl.; Springer: Berlin, Germany, 2009.

52. Schwedt, G. Analytische Chemie: Grundlagen, Methoden und Praxis, 1. Nachdr; Wiley-VCH: Weinheim, Germany, 2004.

53. Armbruster, D.A.; Pry, T. Limit of Blank, Limit of Detection and Limit of Quantitation. Clin. Biochem. Rev. 2008, 49-52.

54. European Union. Council Directive 96/23/EC of 29 April 1996 on Measures to Monitor Certain Substances and Residues Thereof in Live Animals and Animal Products and Repealing Directives 85/358/EEC and 86/469/EEC and Decisions 89/187/EEC and 91/664/EEC. CD 96/23/EC; Official Journal of the European Union; European Union: Brussels, Belgium, 1996; Volume 125, pp. 10-32.

55. Eggins, B.R. Chemical Sensors and Biosensors; Wiley: Chichester, UK, 2002.

56. Schmid, R.D.; Hammelehle, R. Taschenatlas der Biotechnologie und Gentechnik, 2nd ed.; Wiley-VCH: Weinheim, Germany, 2006.

57. Onken, D. Antibiotika: Chemie und Anwendung; Akademie-Verlag: Berlin, Germany, 1985.

58. Song, K.-M.; Jeong, E.; Jeon, W.; Cho, M.; Ban, C. Aptasensor for ampicillin using gold nanoparticle based dual fluorescence-colorimetric methods. Anal. Bioanal. Chem. 2012, 402, 2153-2161. [CrossRef] [PubMed]

59. Dapra, J.; Lauridsen, L.H.; Nielsen, A.T.; Rozlosnik, N. Comparative study on aptamers as recognition elements for antibiotics in a label-free all-polymer biosensor. Biosens. Bioelectron. 2013, 43, 315-320. [CrossRef] [PubMed]

60. Luo, Z.; Wang, Y.; Lu, X.; Chen, J.; Wei, F.; Huang, Z.; Zhou, C.; Duan, Y. Fluorescent aptasensor for antibiotic detection using magnetic bead composites coated with gold nanoparticles and a nicking enzyme. Anal. Chim. Acta 2017, 984, 177-184. [CrossRef] [PubMed]

61. Rosati, G.; Daprà, J.; Cherré, S.; Rozlosnik, N. Performance Improvement by Layout Designs of Conductive Polymer Microelectrode Based Impedimetric Biosensors. Electroanalysis 2014, 26, 1400-1408. [CrossRef]

62. Sun, Y.; Perch-Nielsen, I.; Dufva, M.; Sabourin, D.; Bang, D.D.; Hogberg, J.; Wolff, A. Direct immobilization of DNA probes on non-modified plastics by UV irradiation and integration in microfluidic devices for rapid bioassay. Anal. Bioanal. Chem. 2012, 402, 741-748. [CrossRef] [PubMed]

63. Wang, H.; Wang, Y.; Liu, S.; Yu, J.; Xu, W.; Guo, Y.; Huang, J. Target-aptamer binding triggered quadratic recycling amplification for highly specific and ultrasensitive detection of antibiotics at the attomole level. Chem. Commun. 2015, 51, 8377-8380. [CrossRef] [PubMed]

64. Wang, X.; Dong, S.; Gai, P.; Duan, R.; Li, F. Highly sensitive homogeneous electrochemical aptasensor for antibiotic residues detection based on dual recycling amplification strategy. Biosens. Bioelectron. 2016, 82, 49-54. [CrossRef] [PubMed]

65. Wang, J.; Ma, K.; Yin, H.; Zhou, Y.; Ai, S. Aptamer based voltammetric determination of ampicillin using a single-stranded DNA binding protein and DNA functionalized gold nanoparticles. Microchim. Acta 2018, 185, 589. [CrossRef] [PubMed]

66. Yu, Z.-G.; Lai, R.Y. A reagentless and reusable electrochemical aptamer-based sensor for rapid detection of ampicillin in complex samples. Talanta 2018, 176, 619-624. [CrossRef] [PubMed]

67. Yu, Z.-G.; Sutlief, A.L.; Lai, R.Y. Towards the development of a sensitive and selective electrochemical aptamer-based ampicillin sensor. Sens. Actuators B Chem. 2018, 258, 722-729. [CrossRef] 
68. Gai, P.; Gu, C.; Hou, T.; Li, F. Ultrasensitive Self-Powered Aptasensor Based on Enzyme Biofuel Cell and DNA Bioconjugate: A Facile and Powerful Tool for Antibiotic Residue Detection. Anal. Chem. 2017, 89, 2163-2169. [CrossRef] [PubMed]

69. Zhao, J.; Guo, W.; Pei, M.; Ding, F. GR-Fe $\mathrm{O}_{4}$ NPs and PEDOT-AuNPs composite based electrochemical aptasensor for the sensitive detection of penicillin. Anal. Methods 2016, 8, 4391-4397. [CrossRef]

70. Paniel, N.; Istamboulie, G.; Triki, A.; Lozano, C.; Barthelmebs, L.; Noguer, T. Selection of DNA aptamers against penicillin G using Capture-SELEX for the development of an impedimetric sensor. Talanta 2017, 162, 232-240. [CrossRef] [PubMed]

71. Lee, A.-Y.; Ha, N.-R.; Jung, I.-P.; Kim, S.-H.; Kim, A.-R.; Yoon, M.-Y. Development of a ssDNA aptamer for detection of residual benzylpenicillin. Anal. Biochem. 2017, 531, 1-7. [CrossRef] [PubMed]

72. Rowe, A.A.; Miller, E.A.; Plaxco, K.W. Reagentless measurement of aminoglycoside antibiotics in blood serum via an electrochemical, ribonucleic acid aptamer-based biosensor. Anal. Chem. 2010, 82, 7090-7095. [CrossRef] [PubMed]

73. Wang, Y.; Rando, R.R. Specific binding of aminoglycoside antibiotics to RNA. Chem. Biol. 1995, 2, $281-290$. [CrossRef]

74. Song, K.-M.; Cho, M.; Jo, H.; Min, K.; Jeon, S.H.; Kim, T.; Han, M.S.; Ku, J.K.; Ban, C. Gold nanoparticle-based colorimetric detection of kanamycin using a DNA aptamer. Anal. Biochem. 2011, 415, 175-181. [CrossRef] [PubMed]

75. Niu, S.; Lv, Z.; Liu, J.; Bai, W.; Yang, S.; Chen, A. Colorimetric aptasensor using unmodified gold nanoparticles for homogeneous multiplex detection. PLoS ONE 2014, 9, e109263. [CrossRef] [PubMed]

76. Zhou, N.; Luo, J.; Zhang, J.; You, Y.; Tian, Y. A label-free electrochemical aptasensor for the detection of kanamycin in milk. Anal. Methods 2015, 7, 1991-1996. [CrossRef]

77. Xu, Y.; Han, T.; Li, X.; Sun, L.; Zhang, Y.; Zhang, Y. Colorimetric detection of kanamycin based on analyte-protected silver nanoparticles and aptamer-selective sensing mechanism. Anal. Chim. Acta 2015, 891, 298-303. [CrossRef] [PubMed]

78. Ha, N.-R.; Jung, I.-P.; Kim, S.-H.; Kim, A.-R.; Yoon, M.-Y. Paper chip-based colorimetric sensing assay for ultra-sensitive detection of residual kanamycin. Process Biochem. 2017, 62, 161-168. [CrossRef]

79. Liu, J.; Zeng, J.; Tian, Y.; Zhou, N. An aptamer and functionalized nanoparticle-based strip biosensor for on-site detection of kanamycin in food samples. Analyst 2017, 143, 182-189. [CrossRef] [PubMed]

80. Wang, Y.; Wang, B.; Shen, J.; Xiong, X.; Deng, S. Aptamer based bare eye detection of kanamycin by using a liquid crystal film on a glass support. Microchim. Acta 2017, 184, 3765-3771. [CrossRef]

81. Khabbaz, L.S.; Hassanzadeh-Khayyat, M.; Zaree, P.; Ramezani, M.; Abnous, K.; Taghdisi, S.M. Detection of kanamycin by using an aptamer-based biosensor using silica nanoparticles. Anal. Methods 2015, 7, 8611-8616. [CrossRef]

82. Liu, C.; Lu, C.; Tang, Z.; Chen, X.; Wang, G.; Sun, F. Aptamer-functionalized magnetic nanoparticles for simultaneous fluorometric determination of oxytetracycline and kanamycin. Microchim. Acta 2015, 182, 2567-2575. [CrossRef]

83. Ramezani, M.; Danesh, N.M.; Lavaee, P.; Abnous, K.; Taghdisi, S.M. A selective and sensitive fluorescent aptasensor for detection of kanamycin based on catalytic recycling activity of exonuclease III and gold nanoparticles. Sens. Actuators B Chem. 2016, 222, 1-7. [CrossRef]

84. Li, H.; Sun, D.-E.; Liu, Y.; Liu, Z. An ultrasensitive homogeneous aptasensor for kanamycin based on upconversion fluorescence resonance energy transfer. Biosens. Bioelectron. 2014, 55, 149-156. [CrossRef] [PubMed]

85. Ha, N.-R.; Jung, I.-P.; La, I.-J.; Jung, H.-S.; Yoon, M.-Y. Ultra-sensitive detection of kanamycin for food safety using a reduced graphene oxide-based fluorescent aptasensor. Sci. Rep. 2017, 7, 40305. [CrossRef] [PubMed]

86. Liao, Q.G.; Wei, B.H.; Luo, L.G. Aptamer based fluorometric determination of kanamycin using double-stranded DNA and carbon nanotubes. Microchim. Acta 2017, 184, 627-632. [CrossRef]

87. Wang, Y.; Ma, T.; Ma, S.; Liu, Y.; Tian, Y.; Wang, R.; Jiang, Y.; Hou, D.; Wang, J. Fluorometric determination of the antibiotic kanamycin by aptamer-induced FRET quenching and recovery between $\mathrm{MoS}_{2}$ nanosheets and carbon dots. Microchim. Acta 2017, 184, 203-210. [CrossRef]

88. Robati, R.Y.; Arab, A.; Ramezani, M.; Langroodi, F.A.; Abnous, K.; Taghdisi, S.M. Aptasensors for quantitative detection of kanamycin. Biosens. Bioelectron. 2016, 82, 162-172. [CrossRef] [PubMed] 
89. Xing, Y.-P.; Liu, C.; Zhou, X.-H.; Shi, H.-C. Label-free detection of kanamycin based on a G-quadruplex DNA aptamer-based fluorescent intercalator displacement assay. Sci. Rep. 2015, 5, 8125. [CrossRef] [PubMed]

90. Tang, Y.; Gu, C.; Wang, C.; Song, B.; Zhou, X.; Lou, X.; He, M. Evanescent wave aptasensor for continuous and online aminoglycoside antibiotics detection based on target binding facilitated fluorescence quenching. Biosens. Bioelectron. 2018, 102, 646-651. [CrossRef] [PubMed]

91. Leung, K.-H.; He, H.-Z.; Chan, D.S.-H.; Fu, W.-C.; Leung, C.-H.; Ma, D.-L. An oligonucleotide-based switch-on luminescent probe for the detection of kanamycin in aqueous solution. Sens. Actuators B Chem. 2013, 177, 487-492. [CrossRef]

92. Zhao, M.; Zhuo, Y.; Chai, Y.-Q.; Yuan, R. Au nanoparticles decorated $\mathrm{C}_{60}$ nanoparticle-based label-free electrochemiluminesence aptasensor via a novel "on-off-on" switch system. Biomaterials 2015, 52, 476-483. [CrossRef] [PubMed]

93. Hao, L.; Gu, H.; Duan, N.; Wu, S.; Wang, Z. A chemiluminescent aptasensor for simultaneous detection of three antibiotics in milk. Anal. Methods 2016, 8, 7929-7936. [CrossRef]

94. Bai, X.; Hou, H.; Zhang, B.; Tang, J. Label-free detection of kanamycin using aptamer-based cantilever array sensor. Biosens. Bioelectron. 2014, 56, 112-116. [CrossRef] [PubMed]

95. Zhou, N.; Zhang, J.; Tian, Y. Aptamer-based spectrophotometric detection of kanamycin in milk. Anal. Methods 2014, 6, 1569. [CrossRef]

96. Li, R.; Liu, Y.; Cheng, L.; Yang, C.; Zhang, J. Photoelectrochemical aptasensing of kanamycin using visible light-activated carbon nitride and graphene oxide nanocomposites. Anal. Chem. 2014, 86, 9372-9375. [CrossRef] [PubMed]

97. Xin, Y.; Li, Z.; Zhang, Z. Photoelectrochemical aptasensor for the sensitive and selective detection of kanamycin based on Au nanoparticle functionalized self-doped $\mathrm{TiO}_{2}$ nanotube arrays. Chem. Commun. 2015, 51, 15498-15501. [CrossRef] [PubMed]

98. Lv, J.; Lei, Q.; Xiao, Q.; Li, X.; Huang, Y.; Li, H. Facile fabrication of an "off-on" photoelectrochemical aptasensor for kanamycin detection based on polypyrrole/ $\mathrm{CeO}_{2}$. Anal. Methods 2017, 9, 4754-4759. [CrossRef]

99. Sharma, A.; Istamboulie, G.; Hayat, A.; Catanante, G.; Bhand, S.; Marty, J.L. Disposable and portable aptamer functionalized impedimetric sensor for detection of kanamycin residue in milk sample. Sens. Actuators $B$ Chem. 2017, 245, 507-515. [CrossRef]

100. Zhu, Y.; Chandra, P.; Song, K.-M.; Ban, C.; Shim, Y.-B. Label-free detection of kanamycin based on the aptamer-functionalized conducting polymer/gold nanocomposite. Biosens. Bioelectron. 2012, 36, 29-34. [CrossRef] [PubMed]

101. Sun, X.; Li, F.; Shen, G.; Huang, J.; Wang, X. Aptasensor based on the synergistic contributions of chitosan-gold nanoparticles, graphene-gold nanoparticles and multi-walled carbon nanotubes-cobalt phthalocyanine nanocomposites for kanamycin detection. Analyst 2014, 139, 299-308. [CrossRef] [PubMed]

102. Li, F.; Guo, Y.; Sun, X.; Wang, X. Aptasensor based on thionine, graphene-polyaniline composite film, and gold nanoparticles for kanamycin detection. Eur. Food Res. Technol. 2014, 239, 227-236. [CrossRef]

103. Xu, W.; Wang, Y.; Liu, S.; Yu, J.; Wang, H.; Huang, J. A novel sandwich-type electrochemical aptasensor for sensitive detection of kanamycin based on GR-PANI and PAMAM-Au nanocomposites. New J. Chem. 2014, 38, 4931-4937. [CrossRef]

104. Guo, W.; Sun, N.; Qin, X.; Pei, M.; Wang, L. A novel electrochemical aptasensor for ultrasensitive detection of kanamycin based on MWCNTs-HMIMPF 6 and nanoporous PtTi alloy. Biosens. Bioelectron. 2015, 74, 691-697. [CrossRef] [PubMed]

105. Qin, X.; Guo, W.; Yu, H.; Zhao, J.; Pei, M. A novel electrochemical aptasensor based on MWCNTs-BMIMPF 6 and amino functionalized graphene nanocomposite films for determination of kanamycin. Anal. Methods 2015, 7, 5419-5427. [CrossRef]

106. Qin, X.; Yin, Y.; Yu, H.; Guo, W.; Pei, M. A novel signal amplification strategy of an electrochemical aptasensor for kanamycin, based on thionine functionalized graphene and hierarchical nanoporous $\mathrm{PtCu}$. Biosens. Bioelectron. 2016, 77, 752-758. [CrossRef] [PubMed]

107. Chen, M.; Gan, N.; Zhou, Y.; Li, T.; Xu, Q.; Cao, Y.; Chen, Y. An electrochemical aptasensor for multiplex antibiotics detection based on metal ions doped nanoscale MOFs as signal tracers and RecJf exonuclease-assisted targets recycling amplification. Talanta 2016, 161, 867-874. [CrossRef] [PubMed] 
108. Song, H.-Y.; Kang, T.-F.; Li, N.-N.; Lu, L.-P.; Cheng, S.-Y. Highly sensitive voltammetric determination of kanamycin based on aptamer sensor for signal amplification. Anal. Methods 2016, 8, 3366-3372. [CrossRef]

109. Wang, H.; Wang, Y.; Liu, S.; Yu, J.; Guo, Y.; Xu, Y.; Huang, J. Signal-on electrochemical detection of antibiotics based on exonuclease III-assisted autocatalytic DNA biosensing platform. RSC Adv. 2016, 6, 43501-43508. [CrossRef]

110. Wang, H.; Wang, Y.; Liu, S.; Yu, J.; Guo, Y.; Xu, Y.; Huang, J. Signal-on electrochemical detection of antibiotics at zeptomole level based on target-aptamer binding triggered multiple recycling amplification. Biosens. Bioelectron. 2016, 80, 471-476. [CrossRef] [PubMed]

111. Song, H.-Y.; Kang, T.-F.; Lu, L.-P.; Cheng, S.-Y. Highly sensitive aptasensor based on synergetic catalysis activity of $\mathrm{MoS}_{2}$-Au-HE composite using cDNA-Au-GOD for signal amplification. Talanta 2017, 164, $27-33$. [CrossRef] [PubMed]

112. Huang, S.; Gan, N.; Li, T.; Zhou, Y.; Cao, Y.; Dong, Y. Electrochemical aptasensor for multi-antibiotics detection based on endonuclease and exonuclease assisted dual recycling amplification strategy. Talanta 2018, 179, 28-36. [CrossRef] [PubMed]

113. Nikolaus, N.; Strehlitz, B. DNA-aptamers binding aminoglycoside antibiotics. Sensors 2014, 14, 3737-3755. [CrossRef] [PubMed]

114. Chen, J.; Li, Z.; Ge, J.; Yang, R.; Zhang, L.; Qu, L.-B.; Wang, H.-Q.; Zhang, L. An aptamer-based signal-on bio-assay for sensitive and selective detection of Kanamycin A by using gold nanoparticles. Talanta 2015, 139, 226-232. [CrossRef] [PubMed]

115. Ma, L.; Sun, N.; Tu, C.; Zhang, Q.; Diao, A. Design of an aptamer-based fluorescence displacement biosensor for selective and sensitive detection of kanamycin in aqueous samples. RSC Adv. 2017, 7, 38512-38518. [CrossRef]

116. Liu, R.; Yang, Z.; Guo, Q.; Zhao, J.; Ma, J.; Kang, Q.; Tang, Y.; Xue, Y.; Lou, X.; He, M. Signaling-Probe Displacement Electrochemical Aptamer-based Sensor (SD-EAB) for Detection of Nanomolar Kanamycin A. Electrochim. Acta 2015, 182, 516-523. [CrossRef]

117. Stoltenburg, R.; Nikolaus, N.; Strehlitz, B. Capture-SELEX: Selection of DNA Aptamers for Aminoglycoside Antibiotics. J. Anal. Methods Chem. 2012, 2012, 415697. [CrossRef] [PubMed]

118. Wallis, M.G.; von Ahsen, U.; Schroeder, R.; Famulok, M. A novel RNA motif for neomycin recognition. Chem. Biol. 1995, 2, 543-552. [CrossRef]

119. Ling, K.; Jiang, H.; Zhang, L.; Li, Y.; Yang, L.; Qiu, C.; Li, F.-R. A self-assembling RNA aptamer-based nanoparticle sensor for fluorometric detection of Neomycin B in milk. Anal. Bioanal. Chem. 2016, 408, 3593-3600. [CrossRef] [PubMed]

120. de-los-Santos-Alvarez, N.; Lobo-Castanon, M.J.; Miranda-Ordieres, A.J.; Tunon-Blanco, P. Modified-RNA aptamer-based sensor for competitive impedimetric assay of neomycin B. J. Am. Chem. Soc. 2007, 129, 3808-3809. [CrossRef] [PubMed]

121. de-los-Santos-Alvarez, N.; Lobo-Castanon, M.J.; Miranda-Ordieres, A.J.; Tunon-Blanco, P. SPR sensing of small molecules with modified RNA aptamers: Detection of neomycin B. Biosens. Bioelectron. 2009, 24, 2547-2553. [CrossRef] [PubMed]

122. Spiga, F.M.; Maietta, P.; Guiducci, C. More DNA-Aptamers for Small Drugs: A Capture-SELEX Coupled with Surface Plasmon Resonance and High-Throughput Sequencing. ACS Comb. Sci. 2015, 17, 326-333. [CrossRef] [PubMed]

123. Cappi, G.; Spiga, F.M.; Moncada, Y.; Ferretti, A.; Beyeler, M.; Bianchessi, M.; Decosterd, L.; Buclin, T.; Guiducci, C. Label-free detection of tobramycin in serum by transmission-localized surface plasmon resonance. Anal. Chem. 2015, 87, 5278-5285. [CrossRef] [PubMed]

124. Han, X.; Zhang, Y.; Nie, J.; Zhao, S.; Tian, Y.; Zhou, N. Gold nanoparticle based photometric determination of tobramycin by using new specific DNA aptamers. Microchim. Acta 2018, 185, 340. [CrossRef] [PubMed]

125. Ma, Q.; Wang, Y.; Jia, J.; Xiang, Y. Colorimetric aptasensors for determination of tobramycin in milk and chicken eggs based on DNA and gold nanoparticles. Food Chem. 2018, 249, 98-103. [CrossRef] [PubMed]

126. González-Fernández, E.; de-los-Santos-Álvarez, N.; Lobo-Castañón, M.J.; Miranda-Ordieres, A.J.; Tuñón-Blanco, P. Impedimetric aptasensor for tobramycin detection in human serum. Biosens. Bioelectron. 2010, 26, 2354-2360. [CrossRef] [PubMed] 
127. González-Fernández, E.; de-los-Santos-Álvarez, N.; Lobo-Castañón, M.J.; Miranda-Ordieres, A.J.; Tuñón-Blanco, P. Aptamer-Based Inhibition Assay for the Electrochemical Detection of Tobramycin Using Magnetic Microparticles. Electroanalysis 2011, 23, 43-49. [CrossRef]

128. Schoukroun-Barnes, L.R.; Wagan, S.; White, R.J. Enhancing the analytical performance of electrochemical RNA aptamer-based sensors for sensitive detection of aminoglycoside antibiotics. Anal. Chem. 2014, 86, 1131-1137. [CrossRef] [PubMed]

129. González-Fernández, E.; de-los-Santos-Álvarez, N.; Miranda-Ordieres, A.J.; Lobo-Castañón, M.J. Monovalent labeling system improves the sensitivity of aptamer-based inhibition assays for small molecule detection. Sens. Actuators B Chem. 2013, 182, 668-674. [CrossRef]

130. Zhou, N.; Wang, J.; Zhang, J.; Li, C.; Tian, Y.; Wang, J. Selection and identification of streptomycin-specific single-stranded DNA aptamers and the application in the detection of streptomycin in honey. Talanta 2013, 108, 109-116. [CrossRef] [PubMed]

131. Liu, Z.; Zhang, Y.; Xie, Y.; Sun, Y.; Bi, K.; Cui, Z.; Zhao, L.; Fan, W. An aptamer-based colorimetric sensor for streptomycin and its application in food inspection. Chem. Res. Chin. Univ. 2017, 33, 714-720. [CrossRef]

132. Luan, Q.; Miao, Y.; Gan, N.; Cao, Y.; Li, T.; Chen, Y. A POCT colorimetric aptasensor for streptomycin detection using porous silica beads-enzyme linked polymer aptamer probes and exonuclease-assisted target recycling for signal amplification. Sens. Actuators B Chem. 2017, 251, 349-358. [CrossRef]

133. Zhao, J.; Wu, Y.; Tao, H.; Chen, H.; Yang, W.; Qiu, S. Colorimetric detection of streptomycin in milk based on peroxidase-mimicking catalytic activity of gold nanoparticles. RSC Adv. 2017, 7, 38471-38478. [CrossRef]

134. Emrani, A.S.; Danesh, N.M.; Lavaee, P.; Ramezani, M.; Abnous, K.; Taghdisi, S.M. Colorimetric and fluorescence quenching aptasensors for detection of streptomycin in blood serum and milk based on double-stranded DNA and gold nanoparticles. Food Chem. 2016, 190, 115-121. [CrossRef] [PubMed]

135. Taghdisi, S.M.; Danesh, N.M.; Nameghi, M.A.; Ramezani, M.; Abnous, K. A label-free fluorescent aptasensor for selective and sensitive detection of streptomycin in milk and blood serum. Food Chem. 2016, 203, 145-149. [CrossRef] [PubMed]

136. Xu, X.; Liu, D.; Luo, L.; Li, L.; Wang, K.; You, T. Photoelectrochemical aptasensor based on CdTe quantum dots-single walled carbon nanohorns for the sensitive detection of streptomycin. Sens. Actuators B Chem. 2017, 251, 564-571. [CrossRef]

137. Ghanbari, K.; Roushani, M. A novel electrochemical aptasensor for highly sensitive and quantitative detection of the streptomycin antibiotic. Bioelectrochemistry 2018, 120, 43-48. [CrossRef] [PubMed]

138. Yin, J.; Guo, W.; Qin, X.; Pei, M.; Wang, L.; Ding, F. A regular "signal attenuation" electrochemical aptasensor for highly sensitive detection of streptomycin. New J. Chem. 2016, 40, 9711-9718. [CrossRef]

139. Yin, Y.; Qin, X.; Wang, Q.; Yin, Y. A novel electrochemical aptasensor for sensitive detection of streptomycin based on gold nanoparticle-functionalized magnetic multi-walled carbon nanotubes and nanoporous PtTi alloy. RSC Adv. 2016, 6, 39401-39408. [CrossRef]

140. Yin, J.; Guo, W.; Qin, X.; Zhao, J.; Pei, M.; Ding, F. A sensitive electrochemical aptasensor for highly specific detection of streptomycin based on the porous carbon nanorods and multifunctional graphene nanocomposites for signal amplification. Sens. Actuators B Chem. 2017, 241, 151-159. [CrossRef]

141. Wu, C.; Gan, N.; Ou, C.; Tang, H.; Zhou, Y.; Cao, J. A homogenous "signal-on" aptasensor for antibiotics based on a single stranded DNA binding protein-quantum dot aptamer probe coupling exonuclease-assisted target recycling for signal amplification. RSC Adv. 2017, 7, 8381-8387. [CrossRef]

142. Lin, B.; Yu, Y.; Cao, Y.; Guo, M.; Zhu, D.; Dai, J.; Zheng, M. Point-of-care testing for streptomycin based on aptamer recognizing and digital image colorimetry by smartphone. Biosens. Bioelectron. 2018, 100, 482-489. [CrossRef] [PubMed]

143. Danesh, N.; Ramezani, M.; Sarreshtehdar Emrani, A.; Abnous, K.; Taghdisi, S.M. A novel electrochemical aptasensor based on arch-shape structure of aptamer-complimentary strand conjugate and exonuclease I for sensitive detection of streptomycin. Biosens. Bioelectron. 2016, 75, 123-128. [CrossRef] [PubMed]

144. Lüllmann, H.; Mohr, K.; Wehling, M. Pharmakologie und Toxikologie: Arzneimittelwirkungen Verstehen-Medikamente Gezielt Einsetzen; 14 komplett überarb. und neu gestaltete Aufl.; Thieme: Stuttgart, Germany, 1999.

145. Koolman, J.; Röhm, K.-H. Taschenatlas der Biochemie, 2nd ed.; Thieme: Stuttgart, Germany, 1998. 
146. He, L.; Zhi, W.; Wu, Y.; Zhan, S.; Wang, F.; Xing, H.; Zhou, P. A highly sensitive resonance scattering based sensor using unmodified gold nanoparticles for daunomycin detection in aqueous solution. Anal. Methods 2012, 4, 2266. [CrossRef]

147. Wochner, A.; Menger, M.; Orgel, D.; Cech, B.; Rimmele, M.; Erdmann, V.A.; Glokler, J. A DNA aptamer with high affinity and specificity for therapeutic anthracyclines. Anal. Biochem. 2008, 373, 34-42. [CrossRef] [PubMed]

148. Chandra, P.; Noh, H.-B.; Won, M.-S.; Shim, Y.-B. Detection of daunomycin using phosphatidylserine and aptamer co-immobilized on Au nanoparticles deposited conducting polymer. Biosens. Bioelectron. 2011, 26, 4442-4449. [CrossRef] [PubMed]

149. Hao, L.; Duan, N.; Wu, S.; Xu, B.; Wang, Z. Chemiluminescent aptasensor for chloramphenicol based on $\mathrm{N}$-(4-aminobutyl)- $N$-ethylisoluminol-functionalized flower-like gold nanostructures and magnetic nanoparticles. Anal. Bioanal. Chem. 2015, 407, 7907-7915. [CrossRef] [PubMed]

150. Mehta, J.; van Dorst, B.; Rouah-Martin, E.; Herrebout, W.; Scippo, M.-L.; Blust, R.; Robbens, J. In vitro selection and characterization of DNA aptamers recognizing chloramphenicol. J. Biotechnol. 2011, 155, 361-369. [CrossRef] [PubMed]

151. Gao, H.; Gan, N.; Pan, D.; Chen, Y.; Li, T.; Cao, Y.; Fu, T. A sensitive colorimetric aptasensor for chloramphenicol detection in fish and pork based on the amplification of a nano-peroxidase-polymer. Anal. Methods 2015, 7, 6528-6536. [CrossRef]

152. Miao, Y.; Gan, N.; Li, T.; Zhang, H.; Cao, Y.; Jiang, Q. A colorimetric aptasensor for chloramphenicol in fish based on double-stranded DNA antibody labeled enzyme-linked polymer nanotracers for signal amplification. Sens. Actuators B Chem. 2015, 220, 679-687. [CrossRef]

153. Miao, Y.; Gan, N.; Ren, H.-X.; Li, T.; Cao, Y.; Hu, F.; Yan, Z.; Chen, Y. A triple-amplification colorimetric assay for antibiotics based on magnetic aptamer-enzyme co-immobilized platinum nanoprobes and exonuclease-assisted target recycling. Analyst 2015, 140, 7663-7671. [CrossRef] [PubMed]

154. Miao, Y.-B.; Ren, H.-X.; Gan, N.; Zhou, Y.; Cao, Y.; Li, T.; Chen, Y. A triple-amplification SPR electrochemiluminescence assay for chloramphenicol based on polymer enzyme-linked nanotracers and exonuclease-assisted target recycling. Biosens. Bioelectron. 2016, 86, 477-483. [CrossRef] [PubMed]

155. Miao, Y.-B.; Ren, H.-X.; Gan, N.; Cao, Y.; Li, T.; Chen, Y. Fluorescent aptasensor for chloramphenicol detection using DIL-encapsulated liposome as nanotracer. Biosens. Bioelectron. 2016, 81, 454-459. [CrossRef] [PubMed]

156. Miao, Y.-B.; Gan, N.; Ren, H.-X.; Li, T.; Cao, Y.; Hu, F.; Chen, Y. Switch-on fluorescence scheme for antibiotics based on a magnetic composite probe with aptamer and hemin/G-quadruplex coimmobilized nano-Pt-luminol as signal tracer. Talanta 2016, 147, 296-301. [CrossRef] [PubMed]

157. Wu, S.; Zhang, H.; Shi, Z.; Duan, N.; Fang, C.; Dai, S.; Wang, Z. Aptamer-based fluorescence biosensor for chloramphenicol determination using upconversion nanoparticles. Food Control 2015, 50, 597-604. [CrossRef]

158. Duan, Y.; Wang, L.; Gao, Z.; Wang, H.; Zhang, H.; Li, H. An aptamer-based effective method for highly sensitive detection of chloramphenicol residues in animal-sourced food using real-time fluorescent quantitative PCR. Talanta 2017, 165, 671-676. [CrossRef] [PubMed]

159. Wang, Y.; Gan, N.; Zhou, Y.; Li, T.; Cao, Y.; Chen, Y. Novel single-stranded DNA binding protein-assisted fluorescence aptamer switch based on FRET for homogeneous detection of antibiotics. Biosens. Bioelectron. 2017, 87, 508-513. [CrossRef] [PubMed]

160. Alibolandi, M.; Hadizadeh, F.; Vajhedin, F.; Abnous, K.; Ramezani, M. Design and fabrication of an aptasensor for chloramphenicol based on energy transfer of CdTe quantum dots to graphene oxide sheet. Mater. Sci. Eng. C 2015, 48, 611-619. [CrossRef] [PubMed]

161. Feng, X.; Gan, N.; Zhang, H.; Yan, Q.; Li, T.; Cao, Y.; Hu, F.; Yu, H.; Jiang, Q. A novel “dual-potential” electrochemiluminescence aptasensor array using CdS quantum dots and luminol-gold nanoparticles as labels for simultaneous detection of malachite green and chloramphenicol. Biosens. Bioelectron. 2015, 74, 587-593. [CrossRef] [PubMed]

162. Feng, X.; Gan, N.; Lin, S.; Li, T.; Cao, Y.; Hu, F.; Jiang, Q.; Chen, Y. Ratiometric electrochemiluminescent aptasensor array for antibiotic based on internal standard method and spatial-resolved technique. Sens. Actuators B Chem. 2016, 226, 305-311. [CrossRef]

163. Wang, Y.; Bian, F.; Qin, X.; Wang, Q. Visible light photoelectrochemical aptasensor for chloramphenicol by using a $\mathrm{TiO}_{2}$ nanorod array sensitized with $\mathrm{Eu}(\mathrm{III})$-doped CdS quantum dots. Microchim. Acta 2018, 185, 906. [CrossRef] [PubMed] 
164. Pilehvar, S.; Dardenne, F.; Blust, R.; De wael, K. Electrochemical sensing of phenicol antibiotics at gold. Int. J. Electrochem. Sci 2012, 5000-5011.

165. Pilehvar, S.; Mehta, J.; Dardenne, F.; Robbens, J.; Blust, R.; De Wael, K. Aptasensing of chloramphenicol in the presence of its analogues: Reaching the maximum residue limit. Anal. Chem. 2012, 84, 6753-6758. [CrossRef] [PubMed]

166. Yan, L.; Luo, C.; Cheng, W.; Mao, W.; Zhang, D.; Ding, S. A simple and sensitive electrochemical aptasensor for determination of Chloramphenicol in honey based on target-induced strand release. J. Electroanal. Chem. 2012, 687, 89-94. [CrossRef]

167. Yadav, S.K.; Agrawal, B.; Chandra, P.; Goyal, R.N. In vitro chloramphenicol detection in a Haemophilus influenza model using an aptamer-polymer based electrochemical biosensor. Biosens. Bioelectron. 2014, 55, 337-342. [CrossRef] [PubMed]

168. Bagheri Hashkavayi, A.; Bakhsh Raoof, J.; Ojani, R.; Hamidi Asl, E. Label-Free Electrochemical Aptasensor for Determination of Chloramphenicol Based on Gold Nanocubes-Modified Screen-Printed Gold Electrode. Electroanalysis 2015, 27, 1449-1456. [CrossRef]

169. Hamidi-Asl, E.; Dardenne, F.; Blust, R.; de Wael, K. An improved electrochemical aptasensor for chloramphenicol detection based on aptamer incorporated gelatine. Sensors 2015, 15, 7605-7618. [CrossRef] [PubMed]

170. Rosy, R.; Goyal, R.N.; Shim, Y.-B. Glutaraldehyde sandwiched amino functionalized polymer based aptasensor for the determination and quantification of chloramphenicol. RSC Adv. 2015, 5, 69356-69364. [CrossRef]

171. Yan, Z.; Gan, N.; Wang, D.; Cao, Y.; Chen, M.; Li, T.; Chen, Y. A “signal-on” aptasensor for simultaneous detection of chloramphenicol and polychlorinated biphenyls using multi-metal ions encoded nanospherical brushes as tracers. Biosens. Bioelectron. 2015, 74, 718-724. [CrossRef] [PubMed]

172. Bagheri Hashkavayi, A.; Raoof, J.B.; Azimi, R.; Ojani, R. Label-free and sensitive aptasensor based on dendritic gold nanostructures on functionalized SBA-15 for determination of chloramphenicol. Anal. Bioanal. Chem. 2016, 408, 2557-2565. [CrossRef] [PubMed]

173. Yan, Z.; Gan, N.; Li, T.; Cao, Y.; Chen, Y. A sensitive electrochemical aptasensor for multiplex antibiotics detection based on high-capacity magnetic hollow porous nanotracers coupling exonuclease-assisted cascade target recycling. Biosens. Bioelectron. 2016, 78, 51-57. [CrossRef] [PubMed]

174. Chen, M.; Gan, N.; Li, T.; Wang, Y.; Xu, Q.; Chen, Y. An electrochemical aptasensor for multiplex antibiotics detection using Y-shaped DNA-based metal ions encoded probes with NMOF substrate and CSRP target-triggered amplification strategy. Anal. Chim. Acta 2017, 968, 30-39. [CrossRef] [PubMed]

175. Liu, S.; Lai, G.; Zhang, H.; Yu, A. Amperometric aptasensing of chloramphenicol at a glassy carbon electrode modified with a nanocomposite consisting of graphene and silver nanoparticles. Microchim. Acta 2017, 184, 1445-1451. [CrossRef]

176. Abnous, K.; Danesh, N.M.; Ramezani, M.; Emrani, A.S.; Taghdisi, S.M. A novel colorimetric sandwich aptasensor based on an indirect competitive enzyme-free method for ultrasensitive detection of chloramphenicol. Biosens. Bioelectron. 2016, 78, 80-86. [CrossRef] [PubMed]

177. Liu, Y.; Yan, K.; Okoth, O.K.; Zhang, J. A label-free photoelectrochemical aptasensor based on nitrogen-doped graphene quantum dots for chloramphenicol determination. Biosens. Bioelectron. 2015, 74, 1016-1021. [CrossRef] [PubMed]

178. Pilehvar, S.; Dierckx, T.; Blust, R.; Breugelmans, T.; De Wael, K. An electrochemical impedimetric aptasensing platform for sensitive and selective detection of small molecules such as chloramphenicol. Sensors 2014, 14, 12059-12069. [CrossRef] [PubMed]

179. Lavaee, P.; Danesh, N.M.; Ramezani, M.; Abnous, K.; Taghdisi, S.M. Colorimetric aptamer based assay for the determination of fluoroquinolones by triggering the reduction-catalyzing activity of gold nanoparticles. Microchim. Acta 2017, 11, 81. [CrossRef]

180. Abnous, K.; Danesh, N.M.; Alibolandi, M.; Ramezani, M.; Taghdisi, S.M.; Emrani, A.S. A novel electrochemical aptasensor for ultrasensitive detection of fluoroquinolones based on single-stranded DNA-binding protein. Sens. Actuators B Chem. 2017, 240, 100-106. [CrossRef]

181. Han, S.R.; Yu, J.; Lee, S.-W. In vitro selection of RNA aptamers that selectively bind danofloxacin. Biochem. Biophys. Res. Commun. 2014, 448, 397-402. [CrossRef] [PubMed] 
182. Liu, X.; Su, L.; Zhu, L.; Gao, X.; Wang, Y.; Bai, F.; Tang, Y.; Li, J. Hybrid material for enrofloxacin sensing based on aptamer-functionalized magnetic nanoparticle conjugated with upconversion nanoprobes. Sens. Actuators $B$ Chem. 2016, 233, 394-401. [CrossRef]

183. Liu, X.; Ren, J.; Su, L.; Gao, X.; Tang, Y.; Ma, T.; Zhu, L.; Li, J. Novel hybrid probe based on double recognition of aptamer-molecularly imprinted polymer grafted on upconversion nanoparticles for enrofloxacin sensing. Biosens. Bioelectron. 2017, 87, 203-208. [CrossRef] [PubMed]

184. Pilehvar, S.; Reinemann, C.; Bottari, F.; Vanderleyden, E.; van Vlierberghe, S.; Blust, R.; Strehlitz, B.; de Wael, K. A joint action of aptamers and gold nanoparticles chemically trapped on a glassy carbon support for the electrochemical sensing of ofloxacin. Sens. Actuators B Chem. 2017, 240, 1024-1035. [CrossRef]

185. Reinemann, C.; Freiin von Fritsch, U.; Rudolph, S.; Strehlitz, B. Generation and characterization of quinolone-specific DNA aptamers suitable for water monitoring. Biosens. Bioelectron. 2016, 77, 1039-1047. [CrossRef] [PubMed]

186. Li, S.; Liu, C.; Yin, G.; Zhang, Q.; Luo, J.; Wu, N. Aptamer-molecularly imprinted sensor base on electrogenerated chemiluminescence energy transfer for detection of lincomycin. Biosens. Bioelectron. 2017, 91,687-691. [CrossRef] [PubMed]

187. Niazi, J.H.; Lee, S.J.; Kim, Y.S.; Gu, M.B. ssDNA aptamers that selectively bind oxytetracycline. Bioorg. Med. Chem. 2008, 16, 1254-1261. [CrossRef] [PubMed]

188. Kim, Y.S.; Niazi, J.H.; Gu, M.B. Specific detection of oxytetracycline using DNA aptamer-immobilized interdigitated array electrode chip. Anal. Chim. Acta 2009, 634, 250-254. [CrossRef] [PubMed]

189. Kim, K.; Gu, M.-B.; Kang, D.-H.; Park, J.-W.; Song, I.-H.; Jung, H.-S.; Suh, K.-Y. High-sensitivity detection of oxytetracycline using light scattering agglutination assay with aptasensor. Electrophoresis 2010, 31, 3115-3120. [CrossRef] [PubMed]

190. Kim, Y.S.; Kim, J.H.; Kim, I.A.; Lee, S.J.; Jurng, J.; Gu, M.B. A novel colorimetric aptasensor using gold nanoparticle for a highly sensitive and specific detection of oxytetracycline. Biosens. Bioelectron. 2010, 26, 1644-1649. [CrossRef] [PubMed]

191. Kim, Y.S.; Kim, J.H.; Kim, I.A.; Lee, S.J.; Gu, M.B. The affinity ratio-Its pivotal role in gold nanoparticle-based competitive colorimetric aptasensor. Biosens. Bioelectron. 2011, 26, 4058-4063. [CrossRef] [PubMed]

192. Kim, C.-H.; Lee, L.-P.; Min, J.-R.; Lim, M.-W.; Jeong, S.-H. An indirect competitive assay-based aptasensor for detection of oxytetracycline in milk. Biosens. Bioelectron. 2013, 51, 426-430. [CrossRef] [PubMed]

193. Stoltenburg, R.; Reinemann, C.; Strehlitz, B. FluMag-SELEX as an advantageous method for DNA aptamer selection. Anal. Bioanal. Chem. 2005, 383, 83-91. [CrossRef] [PubMed]

194. Niazi, J.H.; Lee, S.J.; Gu, M.B. Single-stranded DNA aptamers specific for antibiotics tetracyclines. Bioorg. Med. Chem. 2008, 16, 7245-7253. [CrossRef] [PubMed]

195. Kwon, Y.S.; Ahmad Raston, N.H.; Gu, M.B. An ultra-sensitive colorimetric detection of tetracyclines using the shortest aptamer with highly enhanced affinity. Chem. Commun. 2014, 50, 40-42. [CrossRef] [PubMed]

196. Meng, F.; Ma, X.; Duan, N.; Wu, S.; Xia, Y.; Wang, Z.; Xu, B. Ultrasensitive SERS aptasensor for the detection of oxytetracycline based on a gold-enhanced nano-assembly. Talanta 2017, 165, 412-418. [CrossRef] [PubMed]

197. Hou, H.; Bai, X.; Xing, C.; Gu, N.; Zhang, B.; Tang, J. Aptamer-based cantilever array sensors for oxytetracycline detection. Anal. Chem. 2013, 85, 2010-2014. [CrossRef] [PubMed]

198. Seo, H.B.; Kwon, Y.S.; Lee, J.-E.; Cullen, D.; Noh, H.M.; Gu, M.B. A novel reflectance-based aptasensor using gold nanoparticles for the detection of oxytetracycline. Analyst 2015, 140, 6671-6675. [CrossRef] [PubMed]

199. Yuan, F.; Zhao, H.; Zhang, Z.; Gao, L.; Xu, J.; Quan, X. Fluorescent biosensor for sensitive analysis of oxytetracycline based on an indirectly labelled long-chain aptamer. RSC Adv. 2015, 5, 58895-58901. [CrossRef]

200. Tan, B.; Zhao, H.; Du, L.; Gan, X.; Quan, X. A versatile fluorescent biosensor based on target-responsive graphene oxide hydrogel for antibiotic detection. Biosens. Bioelectron. 2016, 83, 267-273. [CrossRef] [PubMed]

201. Zhang, H.; Fang, C.; Wu, S.; Duan, N.; Wang, Z. Upconversion luminescence resonance energy transfer-based aptasensor for the sensitive detection of oxytetracycline. Anal. Biochem. 2015, 489, 44-49. [CrossRef] [PubMed]

202. Yan, K.; Liu, Y.; Yang, Y.; Zhang, J. A Cathodic "Signal-off" Photoelectrochemical Aptasensor for Ultrasensitive and Selective Detection of Oxytetracycline. Anal. Chem. 2015, 87, 12215-12220. [CrossRef] [PubMed] 
203. Li, Y.; Tian, J.; Yuan, T.; Wang, P.; Lu, J. A sensitive photoelectrochemical aptasensor for oxytetracycline based on a signal "switch off-on" strategy. Sens. Actuators B Chem. 2017, 240, 785-792. [CrossRef]

204. Zheng, D.; Zhu, X.; Zhu, X.; Bo, B.; Yin, Y.; Li, G. An electrochemical biosensor for the direct detection of oxytetracycline in mouse blood serum and urine. Analyst 2013, 138, 1886-1890. [CrossRef] [PubMed]

205. Xu, W.; Liu, S.; Yu, J.; Cui, M.; Li, J.; Guo, Y.; Wang, H.; Huang, J. An ultrasensitive HRP labeled competitive aptasensor for oxytetracycline detection based on grapheme oxide-polyaniline composites as the signal amplifiers. RSC Adv. 2014, 4, 10273. [CrossRef]

206. Liu, S.; Wang, Y.; Xu, W.; Leng, X.; Wang, H.; Guo, Y.; Huang, J. A novel sandwich-type electrochemical aptasensor based on GR-3D Au and aptamer-AuNPs-HRP for sensitive detection of oxytetracycline. Biosens. Bioelectron. 2017, 88, 181-187. [CrossRef] [PubMed]

207. Aslipashaki, S.N.; Khayamian, T.; Hashemian, Z. Aptamer based extraction followed by electrospray ionization-ion mobility spectrometry for analysis of tetracycline in biological fluids. J. Chromatogr. B 2013, 925, 26-32. [CrossRef] [PubMed]

208. Liu, Y.; Yan, K.; Zhang, J. Graphitic Carbon Nitride Sensitized with CdS Quantum Dots for Visible-Light-Driven Photoelectrochemical Aptasensing of Tetracycline. ACS Appl. Mater. Interfaces 2015, 28255-28264. [CrossRef] [PubMed]

209. Müller, M.; Weigand, J.E.; Weichenrieder, O.; Suess, B. Thermodynamic characterization of an engineered tetracycline-binding riboswitch. Nucleic Acids Res. 2006, 34, 2607-2617. [CrossRef] [PubMed]

210. Jeong, S.; Rhee Paeng, I. Sensitivity and selectivity on aptamer-based assay: The determination of tetracycline residue in bovine milk. Sci. World J. 2012, 2012, 159456. [CrossRef] [PubMed]

211. He, L.; Luo, Y.; Zhi, W.; Wu, Y.; Zhou, P. A Colorimetric Aptamer Biosensor Based on Gold Nanoparticles for the Ultrasensitive and Specific Detection of Tetracycline in Milk. Aust. J. Chem. 2013, 66, 485. [CrossRef]

212. He, L.; Luo, Y.; Zhi, W.; Zhou, P. Colorimetric Sensing of Tetracyclines in Milk Based on the Assembly of Cationic Conjugated Polymer-Aggregated Gold Nanoparticles. Food Anal. Methods 2013, 6, 1704-1711. [CrossRef]

213. Ramezani, M.; Mohammad Danesh, N.; Lavaee, P.; Abnous, K.; Mohammad Taghdisi, S. A novel colorimetric triple-helix molecular switch aptasensor for ultrasensitive detection of tetracycline. Biosens. Bioelectron. 2015, 70, 181-187. [CrossRef] [PubMed]

214. Wang, R.; Zhou, X.; Liedberg, B.; Zhu, X.; Memon, A.G.; Shi, H. Screening Criteria for Qualified Antibiotic Targets in Unmodified Gold Nanoparticles-Based Aptasensing. ACS Appl. Mater. Interfaces 2017, 9, 35492-35497. [CrossRef] [PubMed]

215. Tang, Y.; Zhang, J.; Liu, J.-H.; Gapparov, I.; Wang, S.; Dong, Y.; Su, H.; Tan, T. The development of a graphene oxide-based aptasensor used for the detection of tetracycline in honey. Anal. Methods 2017, 9, 1133-1140. [CrossRef]

216. Luo, Y.; He, L.; Zhan, S.; Wu, Y.; Liu, L.; Zhi, W.; Zhou, P. Ultrasensitive resonance scattering (RS) spectral detection for trace tetracycline in milk using aptamer-coated nanogold (ACNG) as a catalyst. J. Agric. Food Chem. 2014, 62, 1032-1037. [CrossRef] [PubMed]

217. Li, H.; Chen, Q.; Mehedi Hassan, M.; Chen, X.; Ouyang, Q.; Guo, Z.; Zhao, J. A magnetite/PMAA nanospheres-targeting SERS aptasensor for tetracycline sensing using mercapto molecules embedded core/shell nanoparticles for signal amplification. Biosens. Bioelectron. 2017, 92, 192-199. [CrossRef] [PubMed]

218. Jalalian, S.H.; Taghdisi, S.M.; Danesh, N.M.; Bakhtiari, H.; Lavaee, P.; Ramezani, M.; Abnous, K. Sensitive and fast detection of tetracycline using an aptasensor. Anal. Methods 2015, 7, 2523-2528. [CrossRef]

219. Chen, T.-X.; Ning, F.; Liu, H.-S.; Wu, K.-F.; Li, W.; Ma, C.-B. Label-free fluorescent strategy for sensitive detection of tetracycline based on triple-helix molecular switch and G-quadruplex. CCL 2017, 28, 1380-1384. [CrossRef]

220. Ouyang, Q.; Liu, Y.; Chen, Q.; Guo, Z.; Zhao, J.; Li, H.; Hu, W. Rapid and specific sensing of tetracycline in food using a novel upconversion aptasensor. Food Control 2017, 81, 156-163. [CrossRef]

221. Sun, C.; Su, R.; Bie, J.; Sun, H.; Qiao, S.; Ma, X.; Sun, R.; Zhang, T. Label-free fluorescent sensor based on aptamer and thiazole orange for the detection of tetracycline. Dyes Pigments 2018, 149, 867-875. [CrossRef]

222. Li, H.; Li, J.; Qiao, Y.; Fang, H.; Fan, D.; Wang, W. Nano-gold plasmon coupled with dual-function quercetin for enhanced photoelectrochemical aptasensor of tetracycline. Sens. Actuators B Chem. 2017, 243, 1027-1033. [CrossRef] 
223. Zhang, X.; Zhang, R.; Yang, A.; Wang, Q.; Kong, R.; Qu, F. Aptamer based photoelectrochemical determination of tetracycline using a spindle-like ZnO-CdS@Au nanocomposite. Microchim. Acta 2017, 184, 4367-4374. [CrossRef]

224. Le, T.H.; van Pham, P.; La, T.H.; Phan, T.B.; Le, Q.H. Electrochemical aptasensor for detecting tetracycline in milk. Adv. Nat. Sci. Nanosci. Nanotechnol. 2016, 7, 15008. [CrossRef]

225. Xu, Q.-C.; Zhang, Q.-Q.; Sun, X.; Guo, Y.-M.; Wang, X.-Y. Aptasensors modified by antimony tin oxide nanoparticle-chitosan based on interdigitated array microelectrodes for tetracycline detection. RSC Adv. 2016, 6, 17328-17335. [CrossRef]

226. Zhao, G.; Xu, Q.; Zhang, Q.; Guo, Y.; Sun, X.; Wang, X. Study on Aptasensors Modified by Ionic $\mathrm{Liquid}_{-} \mathrm{Fe}_{3} \mathrm{O}_{4}$ Based on Microarray Electrodes for Tetracycline Detection. Int. J. Electrochem. Sci. 2016, 1699-1706.

227. Hou, W.; Shi, Z.; Guo, Y.; Sun, X.; Wang, X. An interdigital array microelectrode aptasensor based on multi-walled carbon nanotubes for detection of tetracycline. Bioprocess Biosyst. Eng. 2017. [CrossRef] [PubMed]

228. Kim, Y.-J.; Kim, Y.S.; Niazi, J.H.; Gu, M.B. Electrochemical aptasensor for tetracycline detection. Bioprocess Biosyst. 2010, 33, 31-37. [CrossRef] [PubMed]

229. Zhang, J.; Zhang, B.; Wu, Y.; Jia, S.; Fan, T.; Zhang, Z.; Zhang, C. Fast determination of the tetracyclines in milk samples by the aptamer biosensor. Analyst 2010, 135, 2706-2710. [CrossRef] [PubMed]

230. Zhou, L.; Li, D.-J.; Gai, L.; Wang, J.-P.; Li, Y.-B. Electrochemical aptasensor for the detection of tetracycline with multi-walled carbon nanotubes amplification. Sens. Actuators B Chem. 2012, 162, 201-208. [CrossRef]

231. Chen, D.; Yao, D.; Xie, C.; Liu, D. Development of an aptasensor for electrochemical detection of tetracycline. Food Control 2014, 42, 109-115. [CrossRef]

232. Shen, G.; Guo, Y.; Sun, X.; Wang, X. Electrochemical Aptasensor Based on Prussian Blue-Chitosan-Glutaraldehyde for the Sensitive Determination of Tetracycline. Nano-Micro Lett. 2014, 6, 143-152. [CrossRef]

233. Guo, Y.; Wang, X.; Sun, X. A label-free Electrochemical Aptasensor Based on Electrodeposited Gold Nanoparticles and Methylene Blue for Tetracycline Detection. Int. J. Electrochem. Sci. 2015, 3668-3679.

234. Benvidi, A.; Tezerjani, M.D.; Moshtaghiun, S.M.; Mazloum-Ardakani, M. An aptasensor for tetracycline using a glassy carbon modified with nanosheets of graphene oxide. Microchim. Acta 2016, 183, 1797-1804. [CrossRef]

235. Guo, Y.; Zhang, Q.; Xu, Q.; Ma, N.; Sun, X.; Wang, X.Y. Fabrication of aptasensors modified by MWCNTs-CS $/ \mathrm{Fe}_{3} \mathrm{O}_{4}$-CS based on SPEs. Int. J. Electrochem. Sci. 2016, 1691-1698.

236. Jahanbani, S.; Benvidi, A. Comparison of two fabricated aptasensors based on modified carbon paste/oleic acid and magnetic bar carbon paste $/ \mathrm{Fe}_{3} \mathrm{O}_{4} @$ oleic acid nanoparticle electrodes for tetracycline detection. Biosens. Bioelectron. 2016, 85, 553-562. [CrossRef] [PubMed]

237. Taghdisi, S.M.; Danesh, N.M.; Ramezani, M.; Abnous, K. A novel M-shape electrochemical aptasensor for ultrasensitive detection of tetracyclines. Biosens. Bioelectron. 2016, 85, 509-514. [CrossRef] [PubMed]

238. Zhan, X.; Hu, G.; Wagberg, T.; Zhan, S.; Xu, H.; Zhou, P. Electrochemical aptasensor for tetracycline using a screen-printed carbon electrode modified with an alginate film containing reduced graphene oxide and magnetite $\left(\mathrm{Fe}_{3} \mathrm{O}_{4}\right)$ nanoparticles. Microchim. Acta 2016, 183, 723-729. [CrossRef]

239. Xu, Q.; Liu, Z.; Fu, J.; Zhao, W.; Guo, Y.; Sun, X.; Zhang, H. Ratiometric electrochemical aptasensor based on ferrocene and carbon nanofibers for highly specific detection of tetracycline residues. Sci. Rep. 2017, 7, 14729. [CrossRef] [PubMed]

240. Wang, S.; Yong, W.; Liu, J.; Zhang, L.; Chen, Q.; Dong, Y. Development of an indirect competitive assay-based aptasensor for highly sensitive detection of tetracycline residue in honey. Biosens. Bioelectron. 2014, 57, 192-198. [CrossRef] [PubMed]

241. Wang, S.; Liu, J.; Yong, W.; Chen, Q.; Zhang, L.; Dong, Y.; Su, H.; Tan, T. A direct competitive assay-based aptasensor for sensitive determination of tetracycline residue in honey. Talanta 2015, 131, 562-569. [CrossRef] [PubMed]

242. Luo, Y.; Xu, J.; Li, Y.; Gao, H.; Guo, J.; Shen, F.; Sun, C. A novel colorimetric aptasensor using cysteamine-stabilized gold nanoparticles as probe for rapid and specific detection of tetracycline in raw milk. Food Control 2015, 54, 7-15. [CrossRef]

243. Song, K.-M.; Jeong, E.; Jeon, W.; Jo, H.; Ban, C. A coordination polymer nanobelt (CPNB)-based aptasensor for sulfadimethoxine. Biosens. Bioelectron. 2012, 33, 113-119. [CrossRef] [PubMed] 
244. Chen, A.; Jiang, X.; Zhang, W.; Chen, G.; Zhao, Y.; Tunio, T.M.; Liu, J.; Lv, Z.; Li, C.; Yang, S. High sensitive rapid visual detection of sulfadimethoxine by label-free aptasensor. Biosens. Bioelectron. 2013, 42, 419-425. [CrossRef] [PubMed]

245. Liu, J.; Guan, Z.; Lv, Z.; Jiang, X.; Yang, S.; Chen, A. Improving sensitivity of gold nanoparticle based fluorescence quenching and colorimetric aptasensor by using water resuspended gold nanoparticle. Biosens. Bioelectron. 2014, 52, 265-270. [CrossRef] [PubMed]

246. Yan, J.; Huang, Y.; Zhang, C.; Fang, Z.; Bai, W.; Yan, M.; Zhu, C.; Chen, A. Aptamer based photometric assay for the antibiotic sulfadimethoxine based on the inhibition and reactivation of the peroxidase-like activity of gold nanoparticles. Microchim. Acta 2017, 184, 59-63. [CrossRef]

247. Wang, A.; Zhao, H.; Chen, X.; Tan, B.; Zhang, Y.; Quan, X. A colorimetric aptasensor for sulfadimethoxine detection based on peroxidase-like activity of graphene/nickel@palladium hybrids. Anal. Biochem. 2017, 525, 92-99. [CrossRef] [PubMed]

248. Liu, X.; Gao, T.; Gao, X.; Ma, T.; Tang, Y.; Zhu, L.; Li, J. An aptamer based sulfadimethoxine assay that uses magnetized upconversion nanoparticles. Microchim. Acta 2017, 184, 3557-3563. [CrossRef]

249. Okoth, O.K.; Yan, K.; Liu, Y.; Zhang, J. Graphene-doped $\mathrm{Bi}_{2} \mathrm{~S}_{3}$ nanorods as visible-light photoelectrochemical aptasensing platform for sulfadimethoxine detection. Biosens. Bioelectron. 2016, 86, 636-642. [CrossRef] [PubMed]

(C) 2018 by the authors. Licensee MDPI, Basel, Switzerland. This article is an open access article distributed under the terms and conditions of the Creative Commons Attribution (CC BY) license (http://creativecommons.org/licenses/by/4.0/). 